Natália Caron Kitamura

\title{
BIOSSÓLIDO NO ESTABELECIMENTO DE ESPÉCIES HERBÁCEAS E NOS ATRIBUTOS QUÍMICOS E MICROBIOLÓGICOS EM SOLO IMPACTADO PELA MINERAÇÃO DE CARVÃO
}

Dissertação submetida ao Programa de Pós-graduação em Agroecossistemas da Universidade Federal de Santa Catarina para a obtenção do grau de Mestre em Agroecossistemas.

Orientador: Prof. Dr. Cledimar Rogério Lourenzi

Coorientador: Prof. Dr. Admir José Giachini

Florianópolis

2017 
Ficha de identificação da obra elaborada pelo autor, através do Programa de Geração Automática da Biblioteca Universitária da UFSC.

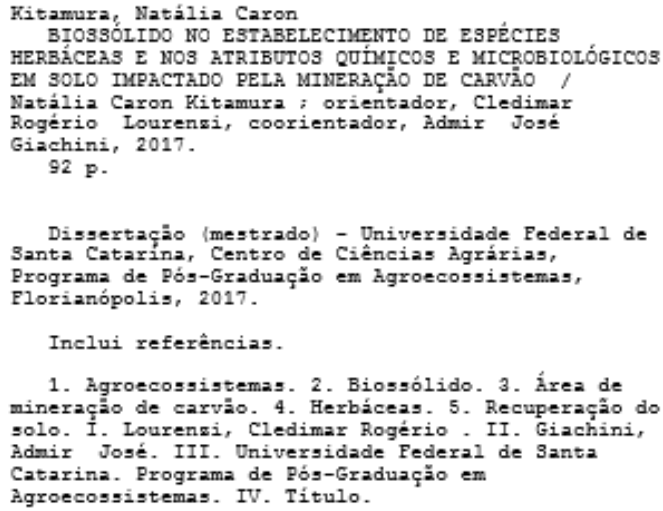




\title{
"Biossólido no Estabelecimento de Espécies Herbáceas e nos Atributos Químicos e Microbiológicos em Solo Impactado pela Mineração de Carvão"
}

\author{
Por
}

\section{NATÁLIA CARON}

Dissertação julgada adequada, em 28/04/2017, e aprovada em sua forma final. pelo Orientador e Membros da Banca Examinadora, para obtençầo do titulo de Mestre em Agroecossistemas. Área de Concentração Agroecologia, no Programa de Pós-Graduação em Agroecossistemas. Centro de Ciências Agrárias/UFSC.

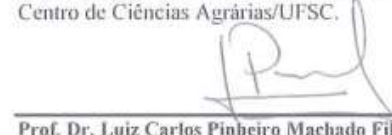

Prof. Dr. Luiz Carlos Pinheiro Machado Fitho (Coordenador do Programa)

\section{Banca Examinadora:}

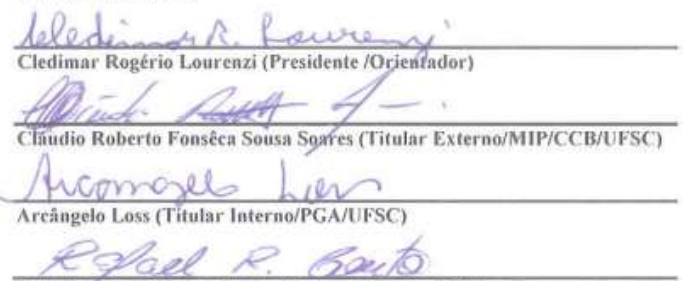

Rafael tra Rosa Couto (Titular Externo/Pós-Doc/PGA)

Candidata ao titulo:

NATALIA CARON 
À minha mãe, com todo meu amor e gratidão, dedico. 


\section{AGRADECIMENTOS}

Aos meus pais e minha irmã pelo apoio, por serem meus maiores exemplos de força, persistência, e por compreenderem minha ausência.

Ao meu marido, Carlos, a quem amo muito, por todo o apoio, ajuda e principalmente pela paciência e compreensão em todos os momentos.

Ao orientador, Cledimar Rogério Lourenzi, pelas orientações e por se mostrar sempre presente. Pelos conselhos seja no âmbito acadêmico, profissional e pessoal, pela leveza, e pelo exemplo de compromisso com a docência e com a profissão.

Ao coorientador, Admir José Giachini, por me orientar desde a graduação, pelo auxílio e força física durante a instalação do experimento a campo. Por acreditar na minha pesquisa e fazê-la acontecer.

Ao grande amigo e futuro mestre, Antonio, pela ajuda durante a etapa experimental e pelas inúmeras conversas na casa de apoio.

Aos colegas do DMS, Manu, Andressa, Anabel, Shantau, Luiz e Edenilson pelo auxílio na realização das análises.

Ao Professor Cláudio pelos sábios esclarecimentos e orientações.

Ao colega Alcenir por realizar todas as análises do solo. O guri é bom!

Aos colegas do PGA/2015, em especial às amigas Jamilli, Mariane e Priscila, pelos encontros, risadas, terapias de grupo, e aprendizado.

Às minhas queridas amigas Laura e Carol, por conviverem com minhas oscilações de humor, sempre passando positividade e confiança. À Fernandinha pela parceria e amizade. E às eternas amigas, Ferdis, Leli e Gabi por existirem.

À minha Família Catarina, tia Dida, tio Clóvis, Arthur e Lu, e Família Kitamura, pelo carinho.

À Professora, eterna Tutora e amiga, Tânia Tarabini Castellani, pelo incentivo, injeção de humor, competência, pelo jeito singular doce e materno.

À empresa Rio Vivo Ambiental pela parceria no projeto e disponibilização do biossólido.

À Carbonífera Metropolitana por disponibilizar a área para estudo. Aos funcionários, Norberto, Denise e Fábio pelo auxílio, 
disponibilidade das sementes, apoio, interesse e comprometimento durante a execução do experimento.

Aos funcionários da UFSC especialmente às secretárias do PGA, Marlene e Fabiana, que estiveram sempre dispostas a ajudar em todas as questões.

Ao Programa de Pós-Graduação em Agroecossistemas pela oportunidade de cursar o mestrado.

À Capes pela concessão da bolsa.

A todos que de alguma forma contribuíram na construção desse trabalho, a minha gratidão! 
"E se a consciência de nossas verdadeiras relações com os restantes seres vivos contribuir para o abandono da noção de propriedade da natura, então sentir-se parente do pássaro que canta em sua janela não vai ser só uma sensação maravilhosa. Vai também ajudar a fazer o mundo melhor". $\sim$ Fernando Fernandez. 


\section{RESUMO}

O biossólido gerado a partir das estações de tratamento de esgotos apresenta-se como uma alternativa frente os grandes volumes de lodo de esgoto produzidos diariamente, e com grande potencial de risco à saúde do meio ambiente e da sociedade. No estado de Santa Catarina, o destino do biossólido, assim como do lodo de esgoto, são os aterros sanitários, sendo desconhecidos outros reaproveitamentos desse resíduo. Dessa forma, o presente estudo tem como objetivo avaliar o efeito da aplicação de diferentes concentrações de biossólido, submetido a tratamento térmico, no estabelecimento de espécies herbáceas (aveia preta, ervilhaca e azevém) e nos atributos químicos e microbiológicos de um solo degradado pela mineração de carvão. Foram instalados dois experimentos (Estudo 1 e Estudo 2), o primeiro em área degradada pela mineração de carvão, localizada no munícipio de Treviso/SC, sendo os tratamentos compostos pelas proporções (v/v) de $0,6,25 ; 100,250$ e 500 $\mathrm{Mg}$ ha $^{-1}$ de biossólido coletado na Estação de Tratamento de Esgoto pertencente à empresa Rio Vivo Ambiental, em Brusque/SC, em parcelas de $2 \times 2 \mathrm{~m}$. O segundo experimento foi conduzido em casa de vegetação, testando-se as concentrações de $0,6,25 ; 250$ e $500 \mathrm{Mg} \mathrm{ha}^{-1}$ do mesmo biossólido em solo sem e com realização de calagem. Em ambos os experimentos foram cultivadas as espécies de aveia preta, ervilhaca e azevém de maneira consorciada. Os parâmetros avaliados foram altura das plantas, produção de matéria seca da parte aérea (MSPA), produção de matéria seca radicular (MSR), teor de $\mathrm{N}$ e $\mathrm{P}$ na parte aérea, contagem de esporos de fungos micorrízicos arbusculares (FMAs) no solo (em $50 \mathrm{~cm}^{3}$ de solo), colonização micorrízica (\%), nodulação radicular, atividade microbiana no solo (respiração basal) e parâmetros da fertilidade do solo. Os principais resultados indicam que o uso de biossólido em áreas degradadas pela mineração de carvão proporcionou melhorias na fertilidade do solo, especialmente, com elevação do $\mathrm{pH}$ do solo, incremento nos teores de nutrientes, como $\mathrm{P}$ e $\mathrm{K}$, e aumento dos teores de carbono orgânico total. Concentrações de $100 \mathrm{Mg} \mathrm{ha}^{-1}$ de biossólido a campo proporcionaram incrementos de 4,2 vezes em altura e em MSR, e 12,5 vezes em MSPA em comparação ao tratamento controle. Além disso, concentrações iguais ou superiores a $250 \mathrm{Mg} \mathrm{ha}{ }^{-1}$ de biossólido na composição do substrato foram prejudiciais ao crescimento de aveia preta, ervilhaca e azevém consorciadas em casa de vegetação. As diferentes concentrações de biossólido não influenciaram os parâmetros colonização micorrízica, respiração basal do solo e nodulação radicular nos dois Estudos 
realizados. A calagem interferiu negativamente na esporulação de FMA em experimento em casa de vegetação. $\mathrm{O}$ uso do biossólido como componente de substrato em áreas degradadas pela mineração de carvão é uma alternativa viável para a disposição final desse resíduo tendo em vista a economia de fertilizante que esse material pode proporcionar, além dos benefícios ambientais, associados a seu uso.

Palavras-chave: áreas degradadas, lodo de esgoto, microrganismos do solo. 


\section{ABSTRACT}

The biosolid generated from the sewage treatment plants is an alternative to the large volumes of sewage sludge produced daily, and with great risk potential to the health of the environment and society. In Santa Catarina, the destination of the biosolid, as well as the sewage sludge, are the sanitary landfills, and other uses of this residue are unknown. Thereby, this study aims to evaluate the effects of different concentrations of biosolid, submitted to thermal treatment, on the establishment of herbaceous species (black oats, vetches and ryegrass) and on the chemical and microbiological attributes of a soil degraded by coal mining. Two field experiments were installed (Study 1 and Study 2 ), the first in an area degraded by coal mining, in Treviso/SC, with treatments composed of proportions (v/v) 0, 6.25, 100, 250 and $500 \mathrm{Mg}$ $\mathrm{ha}^{-1}$ of biosolids collected at the Sewage Treatment Plant from the company Rio Vivo Ambiental, in Brusque/SC, in $2 \times 2 \mathrm{~m}$ plots. The second experiment was conducted under greenhouse conditions, and the concentrations of $0,6.25,250$ and $500 \mathrm{Mg} \mathrm{ha}^{-1}$ of the same biosolid were tested in soil without and with liming. In both experiments the black oat, vetch and ryegrass species were in a consortium cultivated. The parameters used in the analyzes were plant height, production of aerial part dry matter (APDM), production of root dry matter (RDM), $\mathrm{N}$ content in the aerial part, $\mathrm{P}$ content in the aerial part, AMF spore count on the soil (in $50 \mathrm{~cm}$ of soil), mycorrhizal colonization (\%), radicular nodules, the microbial soil activity (basal respiration) soil fertility and $\mathrm{pH}$ of the substrate. The main results indicate that the use of biosolids in areas degraded by coal mining provided improvements in soil fertility, especially with soil $\mathrm{pH}$ elevation, nutrient content levels such as $\mathrm{P}$ and $\mathrm{K}$, and total organic carbon. Concentrations of $100 \mathrm{Mg} \mathrm{ha}^{-1}$ of biosolids in the field provided increases of 4.2 times in height and in MSR, and 12.5 times in MSPA in comparison to the control treatment. In addition, doses equal to or greater than $250 \mathrm{Mg} \mathrm{ha}^{-1}$ of biosolids in the substrate composition have a negative effect on the growth of black oats, vetches and ryegrass consorted in a greenhouse. The different concentrations of biosolids did not influence the parameters mycorrhizal colonization, basal respiration and nodulation in the two studies. Liming interfered negatively in FMA sporulation in a greenhouse experiment. The use of biosolids as a substrate component in areas degraded by coal mining is a viable alternative to a final waste plan in view of a saving of fertilizer that this material can provide in addition to its use.

Keywords: Degraded areas, sewage sludge, soil microorganisms. 


\section{LISTA DE FIGURAS}

Figura 1. Pilhas de rejeito e estéreis da mineração de carvão depositadas na superfície do solo e sobre ação direta do clima. Fonte: Arquivo pessoal, 2016.

Figura 2. Solos construídos após a mineração de carvão a céu aberto. Camada subsuperficial (com rejeitos da mineração) e camada superficial (pouco espessa) com a mistura de horizontes A e/ou B.

22

Figura 3. Imagem aérea da área experimental mantida pela Carbonífera Metropolitana, Treviso/SC. Coordenadas geográficas: $28^{\circ} 28^{\prime} 36^{\prime \prime} \mathrm{S}$ e $49^{\circ} 27^{\prime} 28^{\prime \prime}$ W). Fonte: Google Earth Pro.

Figura 4. Croqui da área experimental, destacando as parcelas e os tratamentos contendo diferentes doses de biossólido. T1 = 0; T2 = 100 $\mathrm{Mg} \mathrm{ha}^{-1} ; \mathrm{T} 3=250 \mathrm{Mg} \mathrm{ha}^{-1} ; \mathrm{T} 4=500 \mathrm{Mg} \mathrm{ha}^{-1} ; \mathrm{T} 5=6,25 \mathrm{Mg} \mathrm{ha}^{-1}$ 44

Figura 5. Experimento a campo no município de Treviso/SC. Fonte: Arquivo pessoal, 2016.

Figura 6. Experimento a campo implantado em 13 de julho de 2017 (A). Aos 36 dias após implantação do experimento (B) e aos 104 dias após implantação (C).

Figura 7. Coleta de amostras de solo das camadas 0-5, 5-10 e 10-20 cm de profundidade, em experimento em área impactada pela mineração de carvão no município de Treviso/SC. Trincheira com dimensões de $30 \mathrm{x}$ 30 x $30 \mathrm{~cm}$ (a). Solo coletado com auxílio de uma pá e utilização de régua graduada para coleta das amostras correspondentes às profundidades (b). Fonte: Arquivo pessoal, 2016.

Figura 8. Utilização de quadrante de $0,25 \mathrm{~m}^{2}$ para coleta de material vegetal no meio das parcelas, em experimento a campo (a). Amostra de material vegetal (aveia preta, ervilhaca e azevém) coletado a campo (b). Fonte: Arquivo pessoal, 2016. 
Figura 9. Experimento em casa de vegetação, implantado em vasos plásticos sobre estande de grade, empregando delineamento fatorial 4x2. Fonte: Arquivo pessoal, 2016.

Figura 10. Separação da parte área e da parte radicular de aveia preta, em experimento utilizando solo de área de mineração + biossólido (a). Raízes de aveia, ervilhaca e azevém no solo cultivado em casa de vegetação com adição de biossólido (b). Fonte: Arquivo pessoal, 2016.

Figura 11. Altura média das plantas (a), matéria seca da parte aérea (b) e matéria seca radicular (c) do consórcio aveia preta, ervilhaca e azevém cultivados a campo em solo degradado pela mineração de carvão com adição de diferentes concentrações de biossólido. Barras verticais representam o desvio padrão da média $(n=5)$. Médias seguidas da mesma letra não diferem entre si pelo teste de Scott-Knott (1974) a 5\% de probabilidade de erro.

Figura 12. Teores de $\mathrm{N}$ (a) e $\mathrm{P}$ (b) em consórcio de aveia preta, ervilhaca e azevém cultivados a campo em solo degradado pela mineração de carvão com adição de diferentes concentrações de biossólido. Barras verticais representam o desvio padrão da média $(n=5)$. Médias seguidas da mesma letra não diferem entre si pelo teste de Scott-Knott (1974) a $5 \%$ de probabilidade de erro. 56

Figura 13. Número de esporos (a), colonização micorrízica (b) e respiração basal (c) nas raízes de aveia preta, ervilhaca e azevém cultivados a campo em solo degradado pela mineração de carvão com adição de diferentes concentrações de biossólido. Barras verticais representam o desvio padrão da média $(n=5)$. Linha tracejada representa a média do número de esporos (a) e respiração basal (c) antes da aplicação do biossólido $(\mathrm{n}=5)$. Médias seguidas da mesma letra não diferem entre si pelo teste de Scott-Knott (1974) a 5\% de probabilidade de erro. 57

Figura 14. Altura das plantas (a), matéria seca da parte aérea (b) matéria seca radicular (c) em substrato de área de mineração, sem e com 
calagem, submetido à aplicação de diferentes doses de biossólido. Barras verticais representam o desvio padrão da média $(n=10)$. Médias seguidas da mesma letra, minúscula entre as doses de biossólido e maiúscula comparando o efeito da calagem na mesma dose de biossólido, não diferem entre si pelo teste de Scott-Knott (1974) a 5\% de probabilidade de erro.

Figura 15. Teores de N (a) e P (b) em consórcio de aveia preta, ervilhaca e azevém em substrato com diferentes concentrações de biossólido em solo com e sem calagem. Barras verticais representam o desvio padrão da média $(\mathrm{n}=10)$. Médias seguidas da mesma letra, minúscula entre as doses de biossólido e maiúscula comparando o efeito da calagem na mesma dose de biossólido, não diferem entre si pelo teste de Scott-Knott (1974) a 5\% de probabilidade de erro. 63

Figura 16. Número de esporos (a) e colonização micorrízica (b) nas raízes de aveia preta, ervilhaca e azevém consorciadas em solo de áreas degradadas pela mineração de carvão, após adição de diferentes doses de biossólido, em experimento conduzido em casa de vegetação. Barras verticais representam o desvio padrão da média $(n=10)$. Linha tracejada representa a média do número de esporos antes da aplicação do biossólido $(\mathrm{n}=10)$. Médias seguidas da mesma letra, minúscula entre as doses de biossólido e maiúscula comparando o efeito da calagem na mesma dose de biossólido, não diferem entre si pelo teste de Scott-Knott (1974) a 5\% de probabilidade de erro. 


\section{LISTA DE TABELAS}

Tabela 1. Classificação do lodo de esgoto ou produto derivado conforme resolução CONAMA 375. 26

Tabela 2. Concentração máxima das substâncias inorgânicas permitidas no lodo de esgoto ou produto derivado ( $\mathrm{mg} \mathrm{kg}^{-1}$, base seca), para uso agrícola.

Tabela 3. Quantidade de insumos para enriquecimento do solo após recuperação com cobertura de argila 37

Tabela 4. Caracterização do biossólido coletado na estação de tratamento de esgoto da empresa Rio Vivo Ambiental, Brusque, Santa Catarina. 47

Tabela 5. Quantificação dos patógenos existentes no biossólido da ETE pertencente à Rio Vivo Ambiental.

Tabela 6. Atributos químicos de solo degradado pela mineração de carvão com adição de diferentes concentrações de biossólido, Carbonífera Metropolitana, Treviso/ SC .............................................. 54

Tabela 7. Atributos químicos do solo coletado em área degradada pela mineração de carvão com presença de estéril de mineração, Carbonífera Metropolitana, Treviso/SC. Resultados obtidos em experimento conduzido em casa de vegetação, utilizando solo com calagem e sem calagem, e quatro tratamentos com doses diferentes de biossólido. ..... 60 


\section{LISTA DE ABREVIATURAS E SIGLAS}

Al - Alumínio;
C - Carbono;
Ca - Cálcio;

CAESB - Companhia de Saneamento Ambiental do Distrito Federal;

CCA - Centro de Ciências Agrárias;

CCB - Centro de Ciências Biológicas;

CETESB - Companhia de Tecnologia de Saneamento Ambiental

CONAMA - Conselho Nacional do Meio Ambiente;

$\mathrm{CO}_{2}$ - Gás carbônico;

DAM - Drenagem Ácida de Minas;

DMS - Laboratório de Diversidade Microbiana do Solo

EEC - European Economic Community;

ETE - Estação de Tratamento de Efluentes;

FAA - Formalina-álcool-ácido acético;

FBN - Fixação biológica de nitrogênio;

FMA - Fungos Micorrízicos Arbusculares;

IBGE - Instituto Brasileiro de Geografia e Estatística;

Mg - Magnésio;

MIP - Microbiologia, Imunologia e Parasitologia;

MSPA - Matéria seca da parte aérea;

MSR - Matéria seca radicular;

$\mathrm{N}$ - Nitrogênio;

$\mathrm{O}_{2}$ - Gás oxigênio;

OMS - Organização Mundial da Saúde;

$\mathrm{P}$ - Fósforo;

pH - Potencial hidrogeniônico;

PNAD - Pesquisa Nacional de Amostra de Domicílios;

PRAD - Projeto de Recuperação de Área Degradada;

RB - Respiração basal do solo;

SANEPAR - Companhia de Saneamento do Paraná;

SBCS - Sociedade Brasileira de Ciência do Solo;

SNIS - Sistema Nacional de Informações sobre Saneamento;

UFSC - Universidade Federal de Santa Catarina;

USDA - United States Department of Agriculture. 


\section{SUMÁRIO}

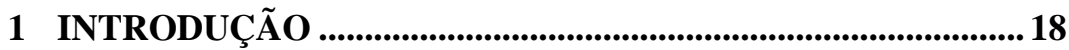

2 REVISÃO BIBLIOGRÁFICA ...................................................... 20

2.1 Solos degradados pela mineração de carvão e os solos

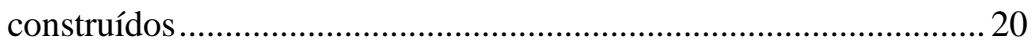

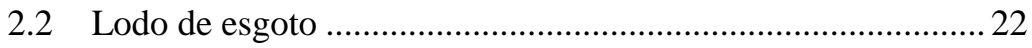

2.3 Higienização do lodo de esgoto para adequação à reciclagem

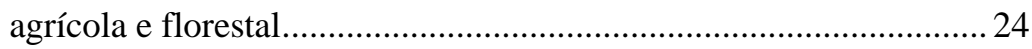

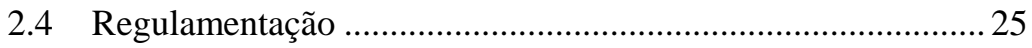

2.5 Benefícios do biossólido e disposição final...............................27

2.6 Recuperação de solos degradados pela mineração de carvão e a revegetação com espécies herbáceas simbiontes .................................30

2.6.1 Aveia preta (Avena strigosa Schreb.)....................................35

2.6.2 Azevém (Lolium multiflorum Lam.) …………………......... 36

2.6.3 Ervilhaca (Vicia sativa L.) ………………………….......... 36

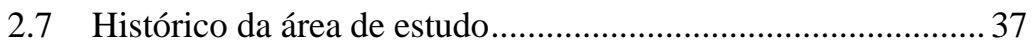

3 HIPÓTESES .....................................................................................39

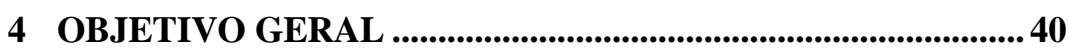

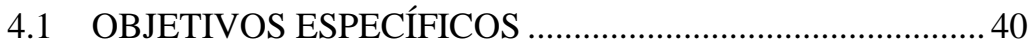

5 MATERIAL E MÉTODOS .......................................................41

5.1 Estudo 1 - Descrição da área experimental, localização, condução, coleta e avaliação do experimento a campo ...................... 41

5.1.1 Descrição da área experimental e tratamentos utilizados .. 41

5.1.2 Obtenção e caracterização do biossólido...............................45

5.1.3 Condução e coleta do experimento …………………….......4 45

5.2 Estudo 2 - Descrição da localização, condução, coleta e avaliação do experimento em casa de vegetação ................................ 49

5.2.1 Descrição da área experimental e tratamentos utilizados... 49

5.2.2 Condução e coleta do experimento ……………………......51

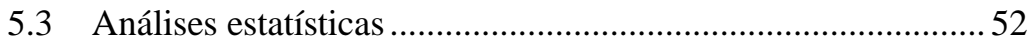

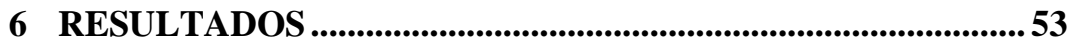

6.1 Estudo 1 - Efeito do biossólido nos atributos químicos do solo em experimento a campo ................................................................ 53

6.2 Estudo 1 - Efeito do biossólido no crescimento de aveia preta, ervilhaca e azevém consorciadas em experimento a campo ..............55 
6.3 Estudo 1 - Efeito do biossólido no teor de nitrogênio e fósforo da parte área das plantas consorciadas em experimento a campo .....56 6.4 Estudo 1 - Efeito do biossólido na colonização micorrízica, esporulação e respiração basal do solo em experimento a campo.....57 6.5 Estudo 1 - Efeito do biossólido na nodulação radicular ...........58 6.6 Estudo 2 - Efeito do biossólido nos atributos químicos do solo em experimento em casa de vegetação

6.7 Estudo 2 - Efeito do biossólido no crescimento de aveia preta, ervilhaca e azevém consorciadas em experimento em casa de vegetação.

6.8 Estudo 2 - Efeito do biossólido no teor de nitrogênio e fósforo da parte área das plantas consorciadas em experimento em casa de vegetação. .62

6.9 Estudo 2 - Efeito do biossólido na colonização micorrízica radicular e esporulação das plantas consorciadas em experimento em

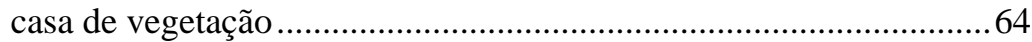

6.10 Estudo 2 - Efeito do biossólido na nodulação radicular .65

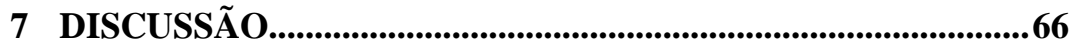

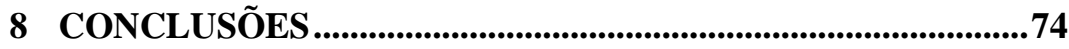

9 CONSIDERAÇÕES FINAIS .....................................................75

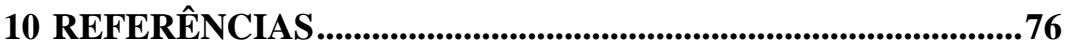




\section{INTRODUÇÃ̃O}

A mineração de carvão na região sul de Santa Catarina teve iniciou no século XX, a partir do surgimento de dezenas de minas em uma área conhecida atualmente como bacia carbonífera (SOARES et al., 2008). A atividade de mineração de carvão contribuiu com o desenvolvimento econômico dos municípios da região carbonífera, principalmente aqueles que substituíram a agricultura pela exploração do carvão mineral (CASTILHOS; FERNANDES, 2011).

$\mathrm{Na}$ primeira metade do século XX, a lavra do carvão era realizada de maneira bastante rudimentar, sendo extraída manualmente a céu aberto ou por meio de galerias de encostas, graduando para uma fase semimecanizada e, posteriormente, mecanizada, não havendo grandes preocupações com o meio ambiente (KOPPE; COSTA, 2002). Apesar da sua importância como recurso energético, sabe-se hoje que a lavra, o beneficiamento e a utilização do carvão mineral são atividades potencialmente poluidoras, que representam elevado risco ambiental, interferindo na paisagem, na contaminação dos solos e dos recursos hídricos (ALBUQUERQUE et al., 2011).

No município de Treviso, assim como em outros municípios pertencentes à região Carbonífera de Santa Catarina, por muitos anos realizou-se a mineração de carvão a céu aberto (BELOLLI et al., 2002). A remoção dos horizontes superficiais do solo, com a consequente remoção da matéria orgânica contida nessa camada, causa sérios problemas na estrutura, disponibilidade de água e nutrientes, além de afetar a atividade biológica do solo (ALEXANDRE, 1999).

As grandes limitações no substrato de solos degradados pela mineração de carvão, principalmente devido à compactação, ao pH ácido e ao baixo teor de nutrientes, principalmente, o $\mathrm{N}$ e o $\mathrm{P}$, tornou essas áreas desfavoráveis ao desenvolvimento vegetal (POLZ, 2008). Nesse sentido, o fornecimento de uma fonte de matéria orgânica é fundamental para garantir o estabelecimento da vegetação nessas áreas.

Existe uma variedade de materiais orgânicos disponíveis para os trabalhos de revegetação de áreas degradadas, cada um com vantagens e desvantagens inerentes. O biossólido, dos sistemas de tratamento de esgotos, é um deles (FARIAS; SANTOS, 2007; SPINOSA, 2007). O biossólido, rico em matéria orgânica e com pH na faixa de 6,5, após sua incorporação aos solos degradados, atua como condicionador, melhorando as propriedades físicas dos solos, aumentando a porosidade e a infiltração de água, facilitando o desenvolvimento das raízes e a 
capacidade de armazenamento de água do solo (GODOY, 2013; RIELING et al., 2015). Além disso, melhora as propriedades químicas e biológicas, complexando elementos-traço, fornecendo e armazenando nutrientes ao solo e às plantas. (TSUTIYA, 2000; ANDREOLI et al, 2001; MELFI; MONTES, 2001).

Empresas de saneamento como a SANEPAR, no Paraná, a CAESB, no Distrito Federal, e a CESAN, no Espírito Santo, já realizam trabalhos de reaproveitamento desse resíduo para fins agronômicos e florestais (CLAPP et al., 1986; BUNDGAARD e SAAYBE, 1992; BONNET et al, 1998; SAMPAIO, 2013). Em Santa Catarina, no entanto, o destino do lodo tratado ainda são os aterros sanitários, o que reflete um cenário oneroso e instável às empresas de tratamento (PIRES; MATTIAZO, 2008) já que, segundo as Políticas Nacionais de Resíduos Sólidos (Lei 12.305/10), é necessário buscar um destino mais nobre para esse resíduo, uma vez que sua deposição em aterro sanitário tem prazo findo muito próximo (BRASIL, 2010).

A aplicação do biossólido em solos e seu uso como substrato é considerada uma alternativa que não apenas resolve o problema da disposição, mas também promove a recuperação dos nutrientes e da matéria orgânica, fundamentais ao melhoramento das características físicas, químicas e biológicas dos solos (LARA et al, 2001).

A legislação brasileira, conforme a Resolução CONAMA 001/86 (BRASIL, 1986), preconiza a obrigatoriedade da recuperação de áreas degradadas pela extração de recursos naturais. Essa recuperação passa pela recomposição topográfica e paisagística, assim como pela reconstrução do solo, a fim do restabelecimento do equilíbrio ecológico (COSTA; ZOCCHE, 2009). A recuperação das áreas impactadas pela mineração do carvão passa primariamente pelo restabelecimento das funções ecológicas do solo, ou seja, pela mitigação dos problemas químicos e físicos dos solos construídos após a mineração de carvão (CAMPOS et al. 2010).

Neste contexto, o presente trabalho buscou avaliar o biossólido, submetido a tratamento térmico, como uma alternativa de uso em programas de recuperação ambiental de áreas degradadas pela mineração de carvão, empregando-o como condicionante de solo e fonte de matéria orgânica para revegetação dessas áreas com espécies herbáceas. 


\section{REVISÃO BIBLIOGRÁFICA}

\subsection{Solos degradados pela mineração de carvão e os solos construídos}

A mineração de carvão em Santa Catarina trouxe benefícios econômicos à região carbonífera do estado, mas resultou na degradação ambiental das áreas mineradas (MENEGHINI, 2014). A mineração de carvão a céu aberto foi uma das principais formas de degradação ambiental na região sul de Santa Catarina (NETO et al., 2008). Nesse processo, as camadas superficiais do solo e de outras formações sedimentares que recobrem as camadas de carvão são removidas, formando as cavas que permitem o acesso à camada de carvão, a qual posteriormente é lavrada. Os estéreis de mineração (rochas e camadas de carvão não aproveitadas) são depositados em pilhas ao lado das cavas de mineração (Figura 1), ficando expostos ao clima (KOPPE; COSTA, 2008).

Figura 1. Pilhas de rejeito e estéreis da mineração de carvão depositadas na superfície do solo e sobre ação direta do clima. Fonte: Arquivo pessoal, 2016.
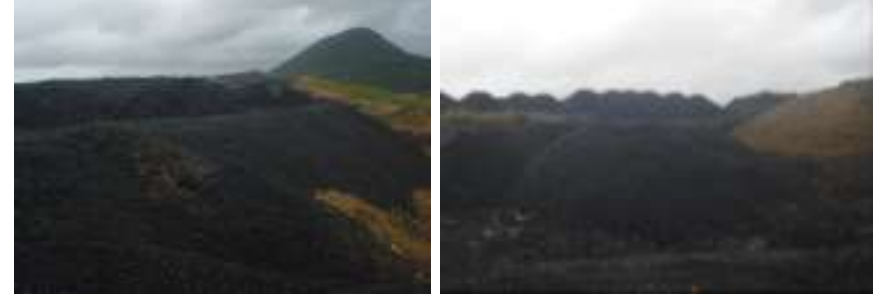

De acordo com Amaral e Krebs (2010), a disposição desordenada de pilhas de estéreis e rejeitos sem proteção, as quais contêm, principalmente, ferro $(\mathrm{Fe})$ e manganês $(\mathrm{Mn})$, constituindo-se em importantes fontes de elementos-traço solubilizados ao solo e aos corpos d'água. Da mesma forma, Nascimento et al. (2002) citam que, a cada $1000 \mathrm{~kg}$ de material minerado, aproximadamente $600 \mathrm{~kg}$ é composto por rejeitos e estéreis da mineração que são depositados no entorno da área minerada, ocasionando problemas ambientais secundários, como a chamada drenagem ácida de mina (DAM), devido a presença da pirita e outros metais sulfetados no rejeito.

As águas de drenagem das minas (céu aberto e subsolo), assim como os efluentes das usinas de beneficiamento, tornam-se ácidas em 
função da oxidação da pirita, material encontrado em elevadas proporções associado aos eventos de extração. $O$ ácido sulfúrico $\left(\mathrm{H}_{2} \mathrm{SO}_{4}\right)$ resultante solubiliza os elementos-traço presentes no minério e nos rejeitos associados, implicando na contaminação dos recursos hídricos. Essa solubilidade dos elementos-traço nos corpos hídricos é função direta do pH. De acordo com Costa et al. (2007), os principais elementos-traço encontrados em áreas de mineração de carvão são: $\mathrm{Cr}$ (cromo), $\mathrm{Zn}$ (zinco), Fe, Co (cobalto), Mn, Ni (níquel), Pb (chumbo) e $\mathrm{Cu}$ (cobre).

Na região carbonífera de Santa Catarina o pH das DAM varia entre 1,5 e 3,0. Nessas condições, grande parte dos compostos contendo elementos-traço é solubilizada, ficando passíveis de lixiviação e contaminação de mananciais, além de dificultarem o estabelecimento de vegetação no local contaminado (DIAS et al., 2005).

Nesse sentido, o impacto causado pela atividade de mineração pode implicar em uma área de influência muito maior que a área de lavra, resultando na retirada da vegetação natural, um intenso revolvimento do solo com grandes volumes de rejeito gerado e a degradação dos recursos hídricos. Estes afetarão toda a bacia hidrográfica, deixando o solo extremamente ácido, $\mathrm{pH}$ entre 3,0 e 3,5, agravando ainda mais o distúrbio ao ambiente (ROCHA-NICOLEITE et al., 2013).

A retirada da vegetação e a consequente perda da matéria orgânica presente nas camadas do solo afetadas pela extração é um grave problema, pois provocam alterações na estrutura do solo, na disponibilidade de água, de macronutrientes, principalmente, o $\mathrm{N}$. Adicionalmente, a retirada da cobertura vegetal deixa o solo desprotegido e sujeito a erosões hídricas e eólicas (POLZ, 2008; SIQUEIRA et al., 2008).

Todos esses agravantes tornam o solo extremamente pobre o que dificulta o desenvolvimento da vegetação. Esses locais perderam ou diminuíram significativamente sua capacidade de recuperação natural, necessitando, portanto, da intervenção antrópica que, ao longo dos anos, promova recuperações pontuais à condição original.

A atividade de mineração de carvão realizada pela Carbonífera Metropolitana se deu através da extração do carvão a céu aberto, na qual se faz a supressão completa da vegetação presente na superfície do solo e a remoção de grandes volumes de solo original e rochas, causando uma intensa alteração topográfica e paisagística no ambiente (DIAS; MELO, 1998). 
A recomposição topográfica das áreas mineradas a céu aberto origina solos antropogênicos denominados de solos construídos. Esses solos caracterizam-se pela presença de uma camada subsuperficial espessa composta por estéreis de mineração e uma camada superficial de solo, constituída pela mistura dos horizontes A e/ou B (PINTO, 1997) (Figura 2).

Figura 2. Solos construídos após a mineração de carvão a céu aberto. Camada subsuperficial (com rejeitos da mineração) e camada superficial (pouco espessa) com a mistura de horizontes A e/ou B.

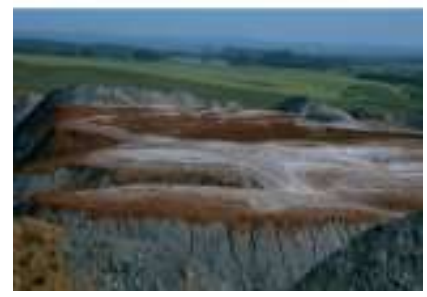

Devido ao processo de recomposição dos solos construídos, há uma mistura do solo com outros materiais geológicos, gerando uma condição muito diferenciada do solo original. Além disso, o movimento de máquinas durante o transporte e deposição da camada de solo afeta de forma negativa a infiltração da água e a aeração do solo, dificultando o futuro desenvolvimento de espécies vegetais nessas áreas (SHRESTHA; LAL, 2011). De modo geral, as propriedades químicas, físicas e biológicas dos solos construídos pós-mineração de carvão refletem a variabilidade herdada dos materiais geológicos, dos diferentes processos construtivos adotados e da mistura do estéril com o solo, limitando o estabelecimento da vegetação e restringindo a recuperação dos solos degradados (CAMPOS et al., 2010).

\subsection{Lodo de esgoto}

Define-se lodo de esgoto como sendo um resíduo semissólido, de textura pastosa e natureza predominantemente orgânica, com teores variáveis de componentes inorgânicos, gerado após o tratamento dos esgotos urbanos (SANEPAR, 1997). Os sistemas de tratamento de esgoto têm como finalidade tornar as águas menos poluídas quando retornadas aos mananciais (EPSTEIN, 2003). 
O termo esgoto é usado para caracterizar os despejos provenientes dos diversos usos da água, como o doméstico, comercial, industrial, agrícola, entre outros. Dessa forma, os esgotos costumam ser classificados em dois grupos principais: os sanitários e os industriais. Os esgotos sanitários, também chamados de domésticos ou domiciliares, apresentam uma constituição essencialmente de despejos domésticos provenientes de instalações como banheiros, cozinhas e lavanderias de residências, edificações públicas e comerciais. Os esgotos industriais, originários da utilização da água para fins industriais, apresentam uma composição extremamente diversificada em função das características específicas de cada processo industrial e do sistema de tratamento empregado na indústria (FERNANDES, 1999).

O esgoto sanitário é composto por uma mistura de líquidos $(99,9 \%)$ e sólidos $(0,01 \%)$. Do total de sólidos, $70 \%$ correspondem à fração orgânica (proteínas, carboidratos e lipídeos), enquanto que 30\% correspondem à fração inorgânica (areia, sais, metais). Essa composição pode variar em função do local de origem, da época do ano e do processo utilizado na Estação Tratamento de Esgoto (ETE) (BETTIOL e CAMARGO, 2006).

Os processos de tratamento de esgoto sanitário, em geral, visam separar as fases sólidas e líquidas. Com isso, há a produção de um resíduo sólido, o lodo de esgoto, e de um efluente que, após passar por etapas de tratamento, pode ser liberado em corpos receptores (COSTA, 2008). Durante o tratamento, a fase sólida é submetida a um processo de digestão e desidratação, parte da fração mineral e da fração orgânica (aquela solúvel em água) permanecem na porção líquida, enquanto a areia, sais e a fração orgânica, insolúveis em água, permanecem na porção sólida. Na fração orgânica encontram-se biomoléculas como carboidratos, proteínas e lipídeos que se constituem em fonte de carbono e de energia para organismos heterotróficos, e cujo metabolismo conduz a liberação de gás carbônico, fosfatos, nitratos e outros íons (BETTIOL e CAMARGO, 2006).

Quanto mais avançado e eficiente for o processo de tratamento de esgoto adotado, maior será a quantidade de lodo produzido, que deve ser gerenciado e disposto adequadamente no meio ambiente (EPSTEIN, 2003). Todavia, o tratamento do esgoto sanitário contempla uma parcela muito pequena dos municípios brasileiros (em torno de 1/3) (SNIS, 2013). O reflexo disso se dá no aspecto ambiental, quando o esgoto sem tratamento é despejado diretamente em corpos d'agua e na superfície do solo. Da mesma forma, os rejeitos originados do tratamento também são 
postos de maneira incorreta, sem nenhum gerenciamento, afetando o meio ambiente.

No Brasil as alternativas de disposição final desse resíduo ainda são os aterros controlados e a incineração, caracterizando um cenário preocupante devido aos graves riscos de poluição ambiental que este resíduo pode acarretar (PIRES; MATTIAZO, 2008). O estado de Santa Catarina gera, em média, 36 mil t ano ${ }^{-1}$ de lodo de esgoto nas estações de tratamento, sem nenhum aproveitamento (RIOVIVO, 2014). Ao contrário disso, o estado do Paraná, por exemplo, é conhecido pelo reaproveitamento do resíduo na área agrícola, como adubo orgânico, e pelo desenvolvimento de pesquisas para a geração de energia a partir do lodo de esgoto (ANDREOLI et al., 1998).

\subsection{Higienização do lodo de esgoto para adequação à reciclagem agrícola e florestal}

O reaproveitamento do lodo torna-se limitado devido à presença de organismos patogênicos e substâncias orgânicas e inorgânicas tóxicas, as quais podem causar toxidez às plantas, atingir direta ou indiretamente a fauna e o homem, comprometendo a sanidade do lodo e a saúde dos ecossistemas (PIRES et al., 2012). Devido ao potencial de risco, o tratamento e a disposição do lodo devem ser controlados para minimizar problemas ambientais como odor, lançamento de contaminantes e patógenos no meio ambiente.

A sanidade do lodo de esgoto e sua reutilização somente são garantidas após o lodo passar por etapas complementares de estabilização, a higienização (PEGORINI e ANDREOLI, 2006). A higienização é a etapa que busca reduzir a concentração de microrganismos patogênicos para não causar riscos à saúde da população e do ambiente como um todo (PINTO, 2001).

Existem diversos processos disponíveis para a desinfecção do lodo de esgoto, tais como pasteurização, digestão aeróbia, digestão anaeróbia, radiação gama, radiação beta, hipercloração, pirólise, compostagem e caleação. A eficiência dos métodos de higienização depende da natureza do patógeno existente no lodo, bem como da qualidade dos processos operacionais da ETE (ANDREOLI et al., 2001).

O processo de secagem térmica é uma das formas mais eficientes e flexíveis de redução de volume e higienização de tortas oriundas do desaguamento de lodos orgânicos, domésticos e industriais, 
disponíveis no mercado. Pode ser utilizado em diferentes tipos de lodo aeróbio, anaeróbio, digeridos ou não (ANDREOLI, 1999).

O processo de higienização a partir da secagem térmica consiste no aquecimento do lodo em ambiente controlado com a aplicação de energia térmica, para a evaporação da água e coleta da umidade removida através da saturação de gases. O lodo precisa ser desidratado até apresentar teor de sólidos na faixa de $20 \%$ a $45 \%$. Após a secagem, o lodo pode adquirir aspecto granular e teores de sólidos na ordem de $90 \%$ a 95\% (FERNANDES et al., 2001). O lodo é então resfriado para estocagem, e os gases destinados ao tratamento e produção do biogás (ANDREOLI, 2001; ANDREOLI e PEGORINI, 2006).

O processo é eficiente para bloquear a atividade biológica no lodo devido à secagem. Todavia, de acordo com Pedroza et al (2006) para garantir a inativação ou eliminação dos microrganismos patogênicos mais termotolerantes é fundamental conhecer a curva de sobrevivência térmica dos organismos presentes no lodo, e o tempo necessário para exposição do lodo a altas temperaturas a fim de se alcançar a higienização. A USEPA (1993), citada em Pedroza et al (2006), recomenda que o lodo seja submetido a uma temperatura de $70^{\circ} \mathrm{C}$ durante um período mínimo de 60 minutos, a fim de garantir a remoção de $90 \%$ de coliformes termotolerantes e Escherischia coli.

$\mathrm{Na}$ Unidade Gerenciadora de Lodo da empresa Rio Vivo Ambiental, os lodos são submetidos ao tratamento complementar por secagem térmica, atingindo os requisitos de temperatura apontados pela literatura para higienização (USEPA, 1993; BARÉS, 2010). De acordo com Andreoli (2001) e Tsutiya et al (2001), para uso agrícola e florestal do lodo de esgoto, assegura-se a redução do volume, a preservação das propriedades agronômicas e a dispensa de equipamentos específicos para manuseio e aplicação em campo.

\subsection{Regulamentação}

A Resolução no 375, do Conselho Nacional do Meio Ambiente CONAMA de 29 de agosto de 2006 define critérios e procedimentos para o uso agrícola de lodos de esgotos gerados em estações de tratamento de esgoto sanitário e seus produtos derivados, como o biossólido.

Na Resolução são abordados aspectos como os indicadores bacteriológicos e agentes patogênicos (Tabela 1), as substâncias inorgânicas e orgânicas potencialmente tóxicas e o potencial 
agronômico do lodo, visando benefícios à agricultura e evitando riscos à saúde pública e ao meio ambiente (BRASIL, 2010). De acordo com a Resolução, fica proibida a utilização de lodo de esgoto ou produto derivado em pastagens e cultivo de olerícolas, tubérculos e raízes, culturas inundadas, bem como as demais culturas cuja parte comestível fique em contato com o solo.

Tabela 1. Classificação do lodo de esgoto ou produto derivado conforme resolução CONAMA 375.

\begin{tabular}{cl}
\hline $\begin{array}{c}\text { Tipo de lodo ou produto } \\
\text { derivado* }\end{array}$ & \multicolumn{1}{c}{ Concentração de patógenos } \\
\hline A & $\begin{array}{l}\text { Coliformes Termotolerantes }<10^{3} \mathrm{NMP} / \mathrm{g} \text { de ST; } \\
\text { Ovos viáveis de helmitos < } 0,25 \text { ovo/g de ST; } \\
\text { Salmonella ausência em } 10 \mathrm{~g} \text { de ST Vírus < 0,25 } \\
\text { UFP ou UFF/g de ST }\end{array}$ \\
\hline B & $\begin{array}{l}\text { Coliformes Termotolerantes }<10^{6} \mathrm{NMP} / \mathrm{g} \text { de ST; } \\
\text { Ovos viáveis de helmintos }<10 \text { ovos /g de ST }\end{array}$ \\
\hline
\end{tabular}

ST: Sólidos Totais; NMP: Números Mais Provável; UFF: Unidade Formadora de Foco; UFP: Unidade Formadora de Placa. *classe A: pode ser utilizado para quaisquer culturas, exceto cultivo de olerícolas, tubérculos e raízes, e culturas inundadas, bem como as demais culturas cuja parte comestível entre em contato com o solo; classe B: a utilização fica restrita ao cultivo de café, à silvicultura e as culturas para produção de fibras e óleos. Fonte: BRASIL (2006).

Da mesma forma, são 11 as substâncias inorgânicas a serem determinadas no lodo de esgoto, segundo a Resolução CONAMA 375/2006, sendo suas concentrações máximas permitidas descritas na Tabela 2.

A CONAMA/375 também exige o monitoramento de substâncias orgânicas no lodo de esgoto, não sendo determinados, no entanto, os limites máximos de concentração. As substâncias orgânicas a serem determinadas no lodo de esgoto ou produto derivado e no solo incluem: benzenos clorados, ésteres de ftalatos, fenóis não clorados, fenóis clorados, hidrocarbonetos aromáticos policíclicos e poluentes orgânicos persistentes (POP`s) (BRASIL, 2006).

Para a caracterização do potencial agronômico do lodo de esgoto ou produto derivado são determinados 13 parâmetros, sendo eles: carbono $(\mathrm{C})$ orgânico, fósforo $(\mathrm{P})$ total, nitrogênio $(\mathrm{N})$ Kjeldahl, $\mathrm{N}$ amoniacal, $\mathrm{N}$ nitrato/nitrito, $\mathrm{pH}$ em água (1:10), potássio $(\mathrm{K})$ total, sódio (Na) total, enxofre $(\mathrm{S})$ total, cálcio $(\mathrm{Ca})$ total, magnésio $(\mathrm{Mg})$ total, umidade, sólidos voláteis e sólidos totais (BRASIL, 2006). 
Tabela 2. Concentração máxima das substâncias inorgânicas permitidas no lodo de esgoto ou produto derivado ( $\mathrm{mg} \mathrm{kg}^{-1}$, base seca), para uso agrícola.

\begin{tabular}{lc}
\hline $\begin{array}{c}\text { Substâncias } \\
\text { Inorgânicas }\end{array}$ & $\begin{array}{c}\text { Concentração máxima permitida }\left(\mathbf{m g ~ k g}^{\mathbf{- 1}},\right. \\
\text { base seca) }\end{array}$ \\
\hline Arsênio & 41 \\
Bário & 1300 \\
Cádmio & 39 \\
Chumbo & 300 \\
Cobre & 1500 \\
Cromo & 1000 \\
Mercúrio & 17 \\
Molibdênio & 50 \\
Níquel & 420 \\
Selênio & 100 \\
Zinco & 2800 \\
\hline
\end{tabular}

Fonte: BRASIL (2006)

A resolução CONAMA/375 refere-se aos parâmetros de qualidade do lodo de esgoto e às características dos locais de aplicação. Adicionalmente, alguns estados brasileiros, como Paraná, com a resolução da Secretaria do Estado do Meio Ambiente (SEMA 021/09) (SERRAT, 2011), São Paulo, com a norma de Aplicação de biossólidos em áreas agrícolas - critérios para projeto e operação - (P4230) (CETESB, 1999), e o Espírito Santo (COSTA; COSTA, 2011) complementaram a resolução nacional, estabelecendo procedimentos e critérios para a utilização alternativa do lodo de esgoto em seus estados. Em Santa Catarina, até o presente, nenhuma lei estadual complementar no que tange esse assunto foi criada.

A reciclagem do lodo de esgoto na agricultura, portanto, exige a produção de um insumo de qualidade assegurada, devendo, necessariamente, estar condicionada a regras que definam os cuidados exigidos para estabilização, desinfecção e normas de utilização que incluam as restrições de uso (PROSAB, 1999).

\subsection{Benefícios do biossólido e disposição final}

O lodo proveniente das estações de tratamento de esgotos sanitários, quando processado, estabilizado e higienizado, de modo a permitir o seu manuseio e utilização de forma segura, recebe o nome de biossólido (BETTIOL; CAMARGO, 2000; SPINOSA, 2007). 
Os biossólidos contêm nutrientes e matéria orgânica que exercem um papel fundamental na manutenção da fertilidade do solo e na produção agrícola (TSUTIYA, 2000). A matéria orgânica presente no biossólido pode aumentar o conteúdo de húmus do solo que, em conjunto com a matéria orgânica já existente, afetam as características físicas, químicas e biológicas do solo. A aplicação do biossólido pode melhorar o estado de agregação das partículas do solo, resultando no aumento da capacidade de armazenamento e de infiltração da água, e reduzindo a erosão do solo (VON SPERLING; GONÇALVES, 2001). Tais características facilitam a penetração das raízes das plantas no solo e estimulam a microbiota do solo (ANDREOLI, 2001).

$\mathrm{O}$ biossólido também pode trazer benefícios às características químicas do solo por aumentar a disponibilidade de macro e micronutrientes, aumentar a capacidade de troca de cátions e complexar elementos tóxicos no solo (MELO; MARQUES, 2000). A presença destes elementos no biossólido depende do esgoto que lhe deu origem e do processo de tratamento de esgoto e de lodo adotado na ETE (MELFI e MONTES, 2001; TSUTIYA, 2001; ANDREOLI et al, 2001).

De acordo com Camargo \& Bettiol (2000), entre os nutrientes advindos do biossólido, destacam-se como os mais relevantes e em maior concentração o $\mathrm{N}$ e o $\mathrm{P}$, elementos limitantes à produção de biomassa vegetal e a presença de microrganismos do solo. Ainda, segundo os mesmos autores, o $\mathrm{N}$ e o $\mathrm{P}$, geralmente, representam $4 \%$ e $2 \%$ da composição do biossólido, respectivamente. Já as quantidades de micronutrientes são variadas, contendo geralmente quantidades apreciáveis de $\mathrm{Cu}, \mathrm{Zn}$ e $\mathrm{Mn}$, e menores quantidades de boro (B), molibdênio (Mo) e cloro $(\mathrm{Cl})$.

$\mathrm{O}$ biossólido pode contribuir ainda para aumentar o $\mathrm{pH}$ e estimular a atividade microbiana do solo (ANDREOLI et al., 1999; ANDREOLI et al., 2001). Em estudo envolvendo a aplicação de biossólido em solo cultivado com Brachiaria sp., Trannin et al. (2007) verificaram aumento nas espécies de fungos micorrízicos arbusculares na área cultivada. Da mesma forma, ao avaliar os efeitos da aplicação do biossólido na nodulação radicular de soja, De Souza et al. (2010) constataram que a presença do resíduo não afetou a nodulação das plantas. Santos et al. (2009) avaliaram em laboratório o efeito de diferentes concentrações de biossólido aplicadas ao solo, e suas consequências na atividade microbiana do solo, e constataram que doses adequadas de biossólido podem estimular a atividade biológica no solo e incrementar o conteúdo de matéria orgânica do solo. 
Por outro lado, a aplicação do lodo de esgoto ou do biossólido nos solos pode causar impactos negativos sobre a biomassa microbiana do solo, devido à presença de metais pesados e substâncias orgânicas e inorgânicas que, em excesso, pode se tornar um passivo ambiental. De acordo com Bettiol e Fernandes (2004), o efeito negativo pode se dar através da ação tóxica direta sobre os microrganismos, por meio de alterações das condições físicas e químicas do ambiente, e consequentes distúrbios funcionais, e pela diminuição da disponibilidade de substratos energéticos essenciais ao desenvolvimento dos microrganismos.

A fim de avaliar o potencial agronômico do biossólido ou do lodo de esgoto, outros autores também testaram o resíduo em cultivos, como os trabalhos desenvolvidos por Backes et al. (2008), que testaram $31 \mathrm{Mg} \mathrm{ha}^{-1}$ de lodo no cultivo de grama esmeralda, Andreoli (1999) realizando experimentos a campo com diferentes doses de lodo $(6,12$ e $18 \mathrm{t} \mathrm{ha}^{-1}$ ) no cultivo de aveia e milho, Trigueiro e Guerrini (2003) empregaram dose de $50 \%$ de lodo de esgoto no cultivo de mudas de eucalipto, Caldeira et al. (2011) utilizaram proporções de 60\%, $80 \%$ e $100 \%$ de biossólido associado ao substrato para cultivo de Tectona grandis, e todos obtiveram resultados bastante positivos no que tange o desenvolvimento e crescimento das plantas. Da mesma forma, Melo et al. (2004) observaram vantagens nas propriedades físicas do solo com a incorporação de $50 \mathrm{t} \mathrm{ha}^{-1}$ de lodo.

A utilização do biossólido no solo aumenta a capacidade de troca catiônica (CTC) e o fornecimento e disponibilidade de $\mathrm{N}$ e P, resultando na melhoria das propriedades do solo, com reflexo na produtividade (MELO et al, 2001; CÔRREA et al. 2010; PIRES et al., 2015). Segundo Sampaio (2013), o N e o P são um dos macronutrientes mais requeridos pelas plantas e, por isso os mais utilizados em culturas agrícolas. Por esta razão, o biossólido não pode ser visto como um simples resíduo, oriundo dos sistemas de tratamento de esgoto, pois suas características físico-químicas o tornam um excelente condicionador do solo (FERREIRA; ANDREOLI, 1999).

O biossólido como adubo orgânico vem se revelando uma alternativa eficaz para a recomposição de solos degradados, influenciando positivamente nas características físicas, químicas e biológicas do solo, bem como na fertilidade das culturas, principalmente aquelas que não são de consumo humano direto (TSUTIYA, 2001).

Nos solos degradados, em que se verifica a perda do horizonte mineral superficial, as condições de desenvolvimento e fixação da vegetação tornam-se comprometidas. Entretanto, estudos mostram que o 
uso do biossólido como condicionador dos solos pode reparar essa condição, possibilitando a recuperação desses ecossistemas. Brofas et al. (2000) e Wisniewski et al. (1996) ressaltam o efeito positivo do emprego do biossólido na recuperação de áreas de mineração. Outros trabalhos demostraram o benefício do uso do biossólido aplicado em solos ácidos, destacando o aumento da produção da biomassa vegetal (NAVAS et al., 1999), o aumento do $\mathrm{pH}$ do solo, e a redução da mobilidade dos elementos-traço, devido a formação de complexos metálicos com a matéria orgânica, diminuindo, assim, a disponibilidade de elementos tóxicos para as plantas (MIYAZAWA et al., 1999).

Dessa forma, a reciclagem do biossólido em solos para fins agrícolas e florestais, bem como para recuperação de solos degradados, mostra-se vantajosa, não apenas pelo potencial agronômico do biossólido, mas também por propiciar um destino final adequado a um resíduo de disposição problemática no Brasil.

\subsection{Recuperação de solos degradados pela mineração de carvão e a revegetação com espécies herbáceas simbiontes}

A perda da fertilidade natural dos solos degradados tem como principal causa o desaparecimento da matéria orgânica. Como consequência disso há um declínio da sua qualidade e da sua capacidade produtiva (FRANCO et al., 1992). A falta de matéria orgânica compromete a estrutura do solo, a disponibilidade de água, a atividade biológica e o suprimento dos nutrientes essenciais às plantas, tendo como consequência a perda de processos e funções chave na sustentabilidade do solo (SIQUEIRA et al., 2007).

Os processos de recuperação se iniciam com a adequação das condições físicas e químicas do solo, visando à introdução de espécies vegetais que garantam o retorno de processos fundamentais ao funcionamento do novo ecossistema e sua estabilização, principalmente relacionado ao ciclo do $\mathrm{N}$ e do carbono (C), e o reestabelecimento da cadeia trófica, bem como das comunidades microbianas do solo (SIQUEIRA et al., 2008).

O fornecimento de uma fonte de matéria orgânica é fundamental para garantir o estabelecimento da vegetação em áreas degradadas pela mineração de carvão. Outra prática de manejo da fertilidade do solo nessas áreas envolve a calagem. Apesar da maioria dos solos brasileiros apresentarem caráter ácido, os solos de área de mineração de carvão em especial são extremamente ácidos $(\mathrm{pH}<4,5)$, 
devido, principalmente, a presença dos estéreis da mineração e da oxidação da pirita (LOPES et al., 1991; CAMPOS et al. 2003). A correção do $\mathrm{pH}$, através aplicação de calcário, tem por finalidade corrigir a acidez do solo e, ao mesmo tempo, diminuir ou tornar indisponíveis metais poluentes presentes no solo como, o $\mathrm{Al}$ e o $\mathrm{Mn}$, reduzindo não somente a fitotoxidez desses elementos, mas também evitando que os mesmos sejam carreados no solo (ERNANI et al., 1996).

Nos estudos de Lunardi Neto et al. (2008) foram avaliaram os efeitos da adubação orgânica com cama de aviário, da revegetação com o cultivo de Brachiaria brizanth e os efeitos da aplicação do calcário nas propriedades físicas dos solos reconstruídos após mineração de carvão. Os autores verificaram que a calagem elevou o $\mathrm{pH}$, respondendo positivamente a correção da acidez solo. A adubação orgânica proporcionou aumento na estabilidade dos agregados e da água prontamente disponível no solo, favorecendo a recuperação da qualidade física do solo degradado.

Ao avaliar o efeito das plantas de cobertura nos atributos físicos de um solo degradado pela mineração do carvão, Gonçalves (2002) concluiu, após três anos de implantação do experimento, que o efeito ainda era bastante incipiente. Já Corrêa \& Bento (2010) constataram melhorias nas propriedades químicas e biológicas de um solo exposto à mineração, após experimento utilizando lodo de esgoto incorporado ao substrato, no cultivo de estrato herbáceo. Os autores relataram também a eficácia do resíduo orgânico para a revegetação de áreas mineradas.

$\mathrm{Na}$ atualidade, a maioria dos projetos de recuperação de áreas degradadas pela mineração de carvão vem utilizando a cama de aviário, casca de arroz, turfa e dejeto suíno para o fornecimento da matéria orgânica no processo de recomposição florística da paisagem dos solos construídos, após recomposição topográfica.

Dessa forma, outro elemento de grande importância nos processos de recuperação ambiental de solos impactados é a cobertura vegetal, naturalmente ocorrente, ou intencionalmente introduzida naquele ambiente (CORREAA; BENTO, 2010). A escolha do tipo de vegetal a ser utilizada é fundamental, considerando-se que na maioria das situações os solos impactados apresentam propriedades físicas desfavoráveis (SHRESTHA; LAL, 2011).

Essa situação é advinda do intenso revolvimento ou compactação do solo, apresentando assim, reduzida capacidade de armazenamento de água, baixa aeração e dificuldade de 
desenvolvimento das raízes, comprometendo o suprimento de nutrientes como P, S e N (NASCIMENTO et al., 1994). A capacidade da espécie vegetal em apresentar associação simbiótica com organismos do solo é de grande relevância, pois promove a fixação do $\mathrm{N}_{2}$ atmosférico, além de permitir uma maior disponibilidade de $\mathrm{P}$, em razão da carência desses nutrientes na maioria dos solos degradados (SIQUEIRA et al., 2008).

A utilização de plantas de cobertura capazes de produzir grande quantidade de fitomassa promove a manutenção da cobertura do solo, propiciando fonte de material orgânico, proteção contra a radiação solar, reduzindo, dessa forma, a perda de água por evaporação (WILDNER; DADALTO, 1991). Adicionalmente, contribui com a ciclagem dos nutrientes, principalmente por beneficiarem a atividade biológica (GASSEN; GASSEN, 1996), buscando restabelecer as estruturas e as funções ecológicas daquele ecossistema, antes da degradação (AUMOND, 2003).

Apesar das condições extremas desses ambientes, muitas espécies herbáceas são utilizadas e recomendadas para recuperação de solos de áreas degradadas pela mineração de carvão (INDA et al., 2010; MARION; FRANCO, 2012; STUMPF et al., 2016), tendo em vista o seu desenvolvimento espontâneo e sua tolerância a ambientes ácidos e de baixa fertilidade (ANDRADE et al., 2009).

As gramíneas (família Poaceae) são espécies que apresentam rápido crescimento inicial (VOLK; COGO, 2008). Tolerantes aos ambientes de baixa fertilidade, essas plantas possuem uma grande quantidade de raízes e alta capacidade de perfilhamento, o que contribui para o melhoramento das características físicas do solo, como porosidade, descompactação e aeração (SILVA; MIELNICZUK, 1997).

De acordo com Silva e Mielniczuk (1997), os efeitos benéficos proporcionados pelas gramíneas estão envolvidos na sua alta densidade radicular, e consequente formação de macro e micro agregados no solo. A ação simultânea de aproximação de partículas minerais e liberação de substâncias orgânicas no perfil do solo, acompanhada da renovação do sistema radicular, pela decomposição das raízes e micélios fúngicos, atuam na formação e estabilização dos agregados (HAYNES; FRANCIS, 1993).

A alta produção de fitomassa das gramíneas também é uma característica que beneficia a estabilização dos agregados e a estruturação do solo. Os resíduos gerados por essas plantas promovem a melhoria do solo, por possuírem maior conteúdo de lignina, possibilitando aumento de ácidos carboxílicos e ácidos húmicos nos 
substratos. (PRIMAVESI, 2002). O material orgânico depositado continuamente serve como fonte de energia para os organismos do solo, cujos subprodutos são constituídos de moléculas orgânicas em diversas fases de decomposição. Dessa forma, além de proteger o solo da incidência direta da radiação solar, e fornecer matéria orgânica para o sistema, fomenta a atividade microbiana (PEREIRA, 2006).

Segundo Perin et al. (2002), a prática de utilizar leguminosas na recuperação de áreas degradadas é de caráter multifuncional, pois associa a manutenção da fertilidade do solo, através da intensa ciclagem de nutrientes, com aspectos de conservação do solo, ficando disponibilizados para as próximas espécies da sucessão vegetal (FRANCO et al., 1992; FRANCO; RESENDE; CAMPELLO, 2003).

De acordo com Marcondes et al. (2010), a associação de plantas leguminosas com bactérias fixadoras de $\mathrm{N}$, genericamente conhecidas como rizóbio, é a principal fonte natural de entrada de $\mathrm{N}$ nos solos. Esses microrganismos promovem a fixação biológica do nitrogênio (FBN) através da quebra da tripla ligação do $\mathrm{N}_{2}$ através de um complexo enzimático denominado nitrogenase. As bactérias convertem $\mathrm{O} \quad \mathrm{N}_{2}$ atmosférico em amônia $\left(\mathrm{NH}_{3}\right)$, que é incorporada em diversas formas de $\mathrm{N}$ orgânico que podem ser utilizadas pelas plantas (DE ARAÚJO; MONTEIRO, 2007).

A maioria das espécies vegetais formam associações mutualistas entre certos fungos presentes no solo e as raízes, as quais se denominam micorrizas. Nessa simbiose, a planta fornece carboidratos necessários ao crescimento e reprodução do fungo, o qual proporciona à planta e ao solo uma série benefícios (MOREIRA; SIQUEIRA, 2006).

As micorrizas, através de suas hifas e micélios, incrementam a absorção de água e nutrientes, especialmente aqueles menos solúveis, como $\mathrm{P}, \mathrm{Zn}$ e $\mathrm{Cu}$, resultando em plantas mais sadias e, portanto, mais resistência às condições ambientais adversas (MOREIRA; SIQUEIRA, 2006). Além dos efeitos nutricionais, fungos micorrízicos arbusculares (FMA) atuam no controle biológico, aumentam a resistência da planta ao ataque de patógenos no sistema radicular e contribuem para a estruturação e agregação do solo (SOARES; SIQUEIRA, 2008).

A literatura reporta ainda o importante sinergismo existente entre rizóbio e FMAs, mostrando que a maior absorção de P, proporcionada pela presença das micorrizas, além de interferirem diretamente no processo de fixação do $\mathrm{N}_{2}$, aumentam a produção de raízes e a fotossíntese, o que aumenta também a nodulação das plantas micorrizadas. Essa interação é de grande interesse na recuperação 
ambiental, devido principalmente à deficiência desses nutrientes no solo, mostrando que a introdução de leguminosas noduladas e micorrizadas em áreas degradadas tem tido bastante sucesso (FRANCO et al., 1995).

Em estudos envolvendo restauração ecológica em solo degradado pela mineração de carvão na China, Bi et al. (2005) verificaram que a aplicação de FMA aumentou a fertilidade do solo e favoreceu a estruturação, aumentando também a atividade biológica. Maschio et al. (1997) submeteram espécies vegetais a um solo degradado pela mineração após a extração de xisto pirobetuminoso no estado do Paraná, e observaram que as espécies inoculadas com FMA e BFN responderam melhor ao estabelecimento no solo contaminado, apresentando menores taxas de mortandade que as espécies não inoculadas. Da mesma forma, Faria et al. (1998) demonstraram os efeitos favoráveis da inoculação de FMA e BFN em áreas degradadas pela mineração após a extração da bauxita no Pará.

Adicionalmente, Soares \& Carneiro (2010) mostram que a recuperação da comunidade de FMA em solos de áreas de mineração de bauxita e a ocorrência espontânea de isolados eficientes são de grande relevância para o avanço da recuperação e completa reabilitação do solo. A atividade de mineração e a consequente retirada da cobertura vegetal dessas áreas causam impactos adversos sobre os organismos e os processos naturais do solo. Dessa forma, os efeitos da reintrodução e da perda desses organismos nos solos degradados devem ser avaliados, como também sua relação com a fertilidade do solo.

No processo de avaliação da qualidade do solo, a biomassa microbiana do solo, que representa todos os organismos menores de $5 \times 10^{-3} \mu \mathrm{m}^{3}$ é frequentemente usada como o primeiro indicador das mudanças nas propriedades químicas e físicas causadas pelo manejo e o estresse ambiental em ecossistemas alterados (BAARU et al., 2007). Outro atributo mensurável relacionado à atividade microbiológica do solo é a respiração basal que envolve a produção de $\mathrm{CO}_{2}$ consumido por $\mathrm{O}_{2}$ como resultado dos processos metabólicos dos microrganismos que se encontram no solo, tais como bactérias, fungos, algas e protozoários. A respiração é um indicador potencial da atividade microbiana no solo, pois é muito sensível em resposta a cobertura vegetal e a adição de material orgânico, sendo capaz de refletir as diferenças entre as práticas de manejo do solo e estresse ambiental (BENINTENDE et al., 2008).

É muito comum considerar que a alta atividade microbiana seja um indicador positivo da qualidade no solo, todavia esses resultados 
devem ser interpretados com critério, já que a alta taxa de respiração pode significar, em curto prazo, a liberação de nutrientes para as plantas e, em longo prazo, a perda de C orgânico do solo para a atmosfera (DE ARAÚJO; MONTEIRO, 2007).

Dessa forma, a respiração microbiana do solo é considerada ferramenta importante na avaliação dos efeitos das condições ambientais sobre a população microbiana do solo, uma vez que pode ser utilizado para avaliar a qualidade do substrato e condições ambientais estressantes, tais como, pouca umidade, baixos teores de matéria orgânica e solos contendo poluentes (ANDERSON e DOMSCH, 2010).

A aplicação de resíduos orgânicos, a calagem e a utilização de espécies vegetais que produzem grande quantidade de biomassa vegetal são práticas necessárias no processo de recuperação ambiental de áreas mineradas (MAÇANEIRO, 2001; MOREIRA, 2004). Adicionalmente, espécies vegetais nodulíferas e que se associam com fungos micorrízicos, torna-se uma ferramenta promissora para a recuperação de solos degradados, uma vez que apresentam características que contribuem para a regeneração de espécies diversas e na reconstituição do solo, elementos preponderantes num processo de recuperação ambiental (FRANCO, CAMPELLO e FARIA, 1994).

A escolha das espécies utilizadas nesse estudo vai ao encontro do Projeto de Recuperação de Áreas Degradadas - PRAD elaborado para as áreas pertencentes à Carbonífera Metropolitana e de responsabilidade da mesma para recuperação ambiental.

\subsubsection{Aveia preta (Avena strigosa Schreb.)}

A aveia preta é uma gramínea de inverno, pertencente à família das poáceas, muito rústica, possui hábito ereto, com desenvolvimento uniforme e bom perfilhamento. A espécie apresenta resistência à seca e tem desenvolvimento rápido. Desenvolve-se em baixas temperaturas, mostrando-se bem adaptada às regiões sul do Brasil (DERPSCH; CALEGARI, 1992). A aveia preta é muito utilizada para cobertura e adubação verde por possuir elevada produção de biomassa e alta de produção de sementes (FLOSS, 1982).. É tolerante à baixa fertilidade e à acidez do solo causada pela presença do alumínio. $\mathrm{O}$ ciclo da cultura normalmente varia de 140 a 180 dias (FONTANELI et al., 2009). Responde positivamente a consorciação com espécies como azevém, centeio, ervilha-forrageira e trevo (REIS; BAIER, 1983a, 1983b). 


\subsubsection{Azevém (Lolium multiflorum Lam.)}

O azevém anual é uma gramínea (família Poaceae), originária do Mediterrâneo, cujo porte chega a atingir 1,2 m de altura. Assim como a aveia preta, o azevém é considerado uma gramínea rústica, com boa capacidade de perfilhamento, apresentando bom desenvolvimento em qualquer tipo de solo. As raízes são superficiais $(5$ a $15 \mathrm{~cm})$ e, por isso, é sensível à seca. Esta gramínea é adaptada a temperaturas baixas, tolera bem a acidez e, desenvolve-se, sobretudo, entre o outono e a primavera (MORAES, 1995).

Apesar de ser conhecido pelo seu potencial como forrageira, o azevém mostra-se como uma excelente alternativa para proteção e cobertura de solo, proporcionando boa produção de massa seca. Adicionalmente, tem a capacidade de produzir quantidades apreciáveis de sementes, favorecendo a ressemeadura natural (DERPSCH; CALEGARI, 1992).

O azevém pode ser cultivado em consórcio com outras gramíneas (aveia, centeio) e com leguminosas (trevos, alfafa, cornichão, ervilhaca). A consorciação com leguminosas, além do aumentar do teor de proteína na forragem, pode também estimular uma maior produção de biomassa. Sob o ponto de vista econômico, a inclusão de leguminosas (fixadoras de nitrogênio atmosférico) permite uma economia na aplicação de $\mathrm{N}$ para as gramíneas (FONTANELI et al., 2009).

\subsubsection{Ervilhaca (Vicia sativa L.)}

A ervilhaca é uma herbácea leguminosa pertencente à família Fabaceae, cujo porte atinge, em média, $0,35 \mathrm{~m}$ de altura. Originária da Europa, essa leguminosa anual resiste bem ao frio, podendo suportar temperaturas de até $-5^{\circ} \mathrm{C}$ (cinco graus negativos). Entretanto, é pouco resistente à seca, e ao excesso de umidade. Produz bem em solos argilosos e férteis, mas adapta-se a solos arenosos adequadamente fertilizados (CALEGARI et al., 1993).

A ervilhaca possui raízes profundas e ramificadas. A alta produção de biomassa vegetal proporciona uma boa cobertura e proteção do solo. Além disso, devido à sua capacidade de fixação de nitrogênio, contribui com a ciclagem dos nutrientes, melhorando a qualidade do solo. Pode ser consorciada com gramínea, como aveia 
preta, centeio e azevém, produzindo maior quantidade de biomassa verde (TOMM, 1990).

\subsection{Histórico da área de estudo}

A ação civil pública 93.8000533-4 de Autoria do Ministério Público Federal condenou solidariamente as empresas carboníferas de Santa Catarina e a União a recuperarem a degradação ambiental provenientes do setor de carvão mineral no Sul de Santa Catarina. Tratase de uma área de mineração a céu aberto, onde as camadas que recobrem o carvão foram removidas e a camada de carvão foi retirada da área e enviada à usina de beneficiamento. A área contabiliza, cerca de 60 hectares e encontra-se totalmente desocupada (PRAD, 2015).

Conforme determina à Lei $\mathrm{n}^{\circ}$ 6.938, de 31 de agosto de 1981, regulamentada pelo Decreto $\mathrm{N}^{\circ} 99.274 / 90$, a recuperação ambiental tem por objetivo o retorno do sítio degradado a uma forma de utilização, de acordo com um plano preestabelecido para o uso do solo, visando à obtenção de uma estabilidade do meio ambiente (PRAD, 2015).

A área objeto deste estudo foi degradada originalmente pela antiga Carbonífera Treviso e a recuperação ambiental ficou sob responsabilidade da União. Conforme Termo de Acordo Judicial Aditivo (TAC), número 2008.72.04.02972-9, a Carbonífera Metropolitana assume a responsabilidade pela recuperação da área Forquilha para que a utilize para implantação do Novo Depósito de Rejeitos, a qual era responsabilidade primária da UNIÃO (PRAD, 2015).

De acordo com o PRAD, as ações de reabilitação envolvem o remodelamento topográfico para disciplinamento das águas superficiais integrando-as ao sistema de drenagem natural existente no entorno, e terraplenagem. As áreas em recuperação recebem material de barreira (camada de $30 \mathrm{~cm}$ de argila), substratos e insumos necessários para a construção do solo e para a sustentação da vegetação, conforme tabela 3.

Tabela 3. Quantidade de insumos para enriquecimento do solo após recuperação com cobertura de argila.

\begin{tabular}{lc}
\hline \multicolumn{1}{c}{ Insumos } & $\mathbf{m}^{\mathbf{3}} \mathbf{h a}$ \\
\hline Turfa & 150 \\
Cama de aviário & 40 \\
Casca de arroz & 40 \\
\hline
\end{tabular}


A camada de argila é espalhada sobre os estéreis e tem por finalidade preencher os vazios e de possibilitar a implantação da vegetação rasteira e protetora até a implantação da vegetação definitiva. A implantação da cobertura vegetal tem a função não só paisagística e ecológica, mas principalmente o controle de processos erosivos e da melhoria do solo destruído pela ação antrópica da extração de carvão a céu aberto. De acordo com o PRAD, as áreas em recuperação, após remodelamento topográfico e enriquecimento do solo, recebem semeadura de espécies herbáceas, em consorciação de duas gramíneas e uma leguminosa, respeitando-se a época do ano (inverno e verão). São utilizadas as seguintes espécies: Calopogônio (Calopogonium muconoides), Pojuca (Paspalum atratum), Braquiaria (Braquiaria brizanta), Ervilhaca (Vicia sativa), Azevém (Lolium multiflorum) e Aveia preta (Avena sativa). 


\section{HIPÓTESES}

a) A adição de biossólido favorece o estabelecimento de espécies herbáceas consorciadas em solo degradado pela mineração de carvão;

b) A adição de biossólido em solo degradado pela mineração de carvão tem efeitos positivos nas associações micorrízica e com bactérias fixadoras de nitrogênio em plantas herbáceas;

c) A adição de biossólido em solo degradado pela mineração de carvão estimula a atividade microbiana no solo. 


\section{OBJETIVO GERAL}

Avaliar o emprego de biossólido, submetido a tratamento térmico, como componente de substrato para o estabelecimento de plantas herbáceas e os seus efeitos sobre a atividade microbiana de um solo impactado pela mineração de carvão no sul de Santa Catarina.

\subsection{OBJETIVOS ESPECÍFICOS}

1) Avaliar o emprego de biossólido no crescimento e desenvolvimento de consorcio com aveia preta, ervilhaca e azevém, cultivadas em solo impactado pela mineração de carvão;

2) Avaliar o emprego de biossólido na colonização das espécies vegetais por fungos micorrízicos arbusculares e bactérias fixadoras de nitrogênio em solo impactado pela mineração de carvão;

3) Avaliar o efeito de biossólido nos atributos químicos e na atividade microbiana do solo (respiração microbiana);

4) Determinar a concentração mais adequada de biossólido para incorporação ao solo de áreas degradadas pela mineração de carvão;

5) Avaliar o efeito da calagem e da adição de biossólido na correção do $\mathrm{pH}$ de solo de área degradada pela mineração de carvão. 


\section{MATERIAL E MÉTODOS}

A fim de cumprir os objetivos da dissertação foram desenvolvidos dois Estudos.

O Estudo 1 trata-se de um experimento realizado a campo, em área degradada pela mineração de carvão, no município de Treviso/SC, em que se avaliou o efeito de diferentes concentrações de biossólido, incorporadas superficialmente ao solo, nos atributos químicos e na atividade microbiana do solo, no crescimento e desenvolvimento a campo de aveia preta, azevém e ervilhaca e seus efeitos sobre os FMA e BFN.

O Estudo 2 envolveu um experimento realizado em casa de vegetação, em que se avaliou o efeito da calagem em um substrato base, contendo solo de área de mineração de carvão e diferentes concentrações de biossólido, sob os atributos químicos do solo, no crescimento e desenvolvimento de aveia preta, azevém e ervilhaca e seus efeitos sobre os FMA e BFN.

\subsection{Estudo 1 - Descrição da área experimental, localização, condução, coleta e avaliação do experimento a campo}

\subsubsection{Descrição da área experimental e tratamentos utilizados}

$\mathrm{O}$ experimento foi instalado em área pertence à Carbonífera Metropolitana S/A e está localizada no município de Treviso/SC (Figura 3). O acesso principal a área é através da rodovia $\mathrm{SC}-447$, que liga Siderópolis a Treviso.

Figura 3. Imagem aérea da área experimental mantida pela Carbonífera Metropolitana, Treviso/SC. Coordenadas geográficas: $28^{\circ} 28^{\prime} 36^{\prime \prime} \mathrm{S}$ e $49^{\circ} 27^{\prime}$ 28" W). Fonte: Google Earth Pro.

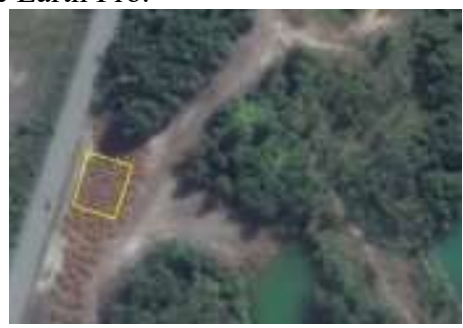


O clima da região é do tipo Cfa, conforme classificação de Köppen. A temperatura média anual varia entre 17,0 e $19,3{ }^{\circ} \mathrm{C}$, com índices pluviométricos que variam entre 1.220 e $1.660 \mathrm{~mm}$ (EPAGRI, 2001). O solo da área pós-mineração encontra-se bastante descaracterizado devido ao intenso revolvimento das camadas e a deposição de estéreis de mineração na superfície, sendo assim de difícil identificação. No entanto, o solo que predomina na região é do tipo Cambissolo (EPAGRI, 2001).

O experimento foi implantado no dia 13 de julho de 2016 em, aproximadamente, $500 \mathrm{~m}^{2}$ de área intensamente minerada, a qual recebeu uma camada de $30 \mathrm{~cm}$ de solo argiloso, proveniente de solo de área de empréstimo com baixo teor de matéria orgânica. Inicialmente amostras de solo foram coletas nas camadas de 0-5, 5-10 e 10-20 cm de profundidade, em cinco pontos distintos dentro da área de implantação do experimento. A coleta foi realizada antes da aplicação do biossólido e as amostras foram acondicionadas em sacos plásticos e levadas até o laboratório de análise de solo, água e tecidos vegetais do departamento de Engenharia Rural da Universidade Federal de Santa Catarina (ENR/UFSC) para posteriores análises químicas do solo. As características do solo antes da instalação do experimento são apresentadas na tabela 3 .

O delineamento experimental utilizado foi de blocos inteiramente casualizados, utilizando cinco tratamentos e dez repetições, distribuídos em 50 unidades experimentais de $2 \times 2 \mathrm{~m}$. Entre as unidades experimentais foram deixadas faixas com $1 \mathrm{~m}$ de largura, não tratadas (Figura 4 e Figura 5). Os tratamentos foram constituídos pelas doses de biossólido de: $0 ; 6,25 ; 100 ; 250$ e $500 \mathrm{Mg} \mathrm{ha}^{-1}$, incorporados ao solo, com auxílio de enxadas.

Tabela 3. Parâmetros químicos do solo degradado pela mineração de carvão, antes da instalação do experimento a campo, em área pertencente à Carbonífera Metropolitana, Treviso/SC.

\begin{tabular}{lcccccc}
\hline \multirow{2}{*}{ Prof., cm } & \multicolumn{7}{c}{ Atributos do solo } \\
\cline { 2 - 7 } & $\mathrm{pH}$ & $\mathrm{H}+\mathrm{Al}$ & $\mathrm{Al}$ & $\mathrm{P}$ & $\mathrm{K}$ & $\mathrm{C}$ \\
\cline { 2 - 7 } & \multicolumn{7}{c}{$-\mathrm{cmol}_{\mathrm{c}} \mathrm{dm}^{-3}-$} & $---\mathrm{mg} \mathrm{kg}^{-1}---$ & $\mathrm{g} \mathrm{kg}^{-1}$ \\
\hline $0-5$ & 3,89 & 2,75 & 9,53 & 16,29 & 13,20 & 15,76 \\
$5-10$ & 3,93 & 3,39 & 10,02 & 16,55 & 13,40 & 15,89 \\
$10-20$ & 3,84 & 3,45 & 9,40 & 16,71 & 12,00 & 15,02 \\
\hline
\end{tabular}


A escolha das doses de biossólido empregadas no experimento está relacionada às exigências legais conforme CONAMA 375/2006, a recomendação da CQFS-RS/SC (2016) para o fornecimento de $\mathrm{N}$ às culturas, e aos inúmeros trabalhos já publicados, envolvendo a aplicação de lodo de esgoto e biossólido na agricultura e na recuperação de áreas degradadas. Nos estados de Santa Catarina e Rio Grande do Sul, a quantidade de $\mathrm{N}$ recomendada para o consórcio de gramíneas e de leguminosas de inverno é de $20 \mathrm{~kg} \mathrm{ha}^{-1}$ (CQFS-RS/SC, 2016).

Em cada parcela foram semeadas, a lanço, $145 \mathrm{~g}$ de um consórcio de sementes de aveia preta $(80 \mathrm{~g})$, ervilhaca (40 g) e azevém (25 g) (200 kg ha ${ }^{-1}, 100 \mathrm{~kg} \mathrm{ha}^{-1} \mathrm{e} 62,5 \mathrm{~kg} \mathrm{ha}^{-1}$, respectivamente). As sementes de aveia preta, ervilhaca e azevém foram fornecidas pela Carbonífera Metropolitana, e permaneceram armazenadas em sacos plásticos até o plantio.

Devido às fortes chuvas que atingiram a região no mês de agosto de 2016, e tendo em vista a grande perda de sementes por carreamento durante a fase de implantação do experimento, as parcelas tiveram que ser ressemeadas um mês após a instalação do experimento. Nesse sentido, cada parcela recebeu novamente $145 \mathrm{~g}$ do consórcio de sementes de aveia preta $(80 \mathrm{~g})$, ervilhaca $(40 \mathrm{~g})$ e azevém $(25 \mathrm{~g})$. A emergência das plantas ocorreu a partir do $10^{\circ}$ dia pós-ressemeadura. 
Figura 4. Croqui da área experimental, destacando as parcelas e os tratamentos contendo diferentes doses de biossólido. $\mathrm{T} 1=0 ; \mathrm{T} 2=100 \mathrm{Mg} \mathrm{ha}^{-1} ; \mathrm{T} 3=250$ $\mathrm{Mg} \mathrm{ha}^{-1} ; \mathrm{T} 4=500 \mathrm{Mg} \mathrm{ha}^{-1} ; \mathrm{T} 5=6,25 \mathrm{Mg} \mathrm{ha}^{-1}$.

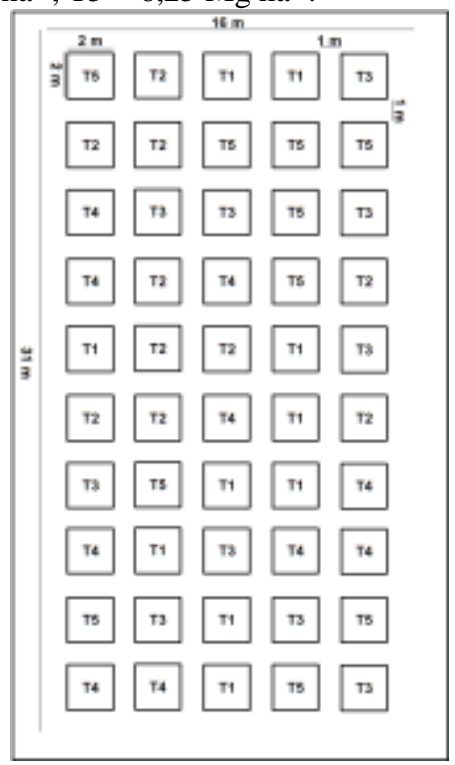

Figura 5. Experimento a campo no município de Treviso/SC. Fonte: Arquivo pessoal, 2016.

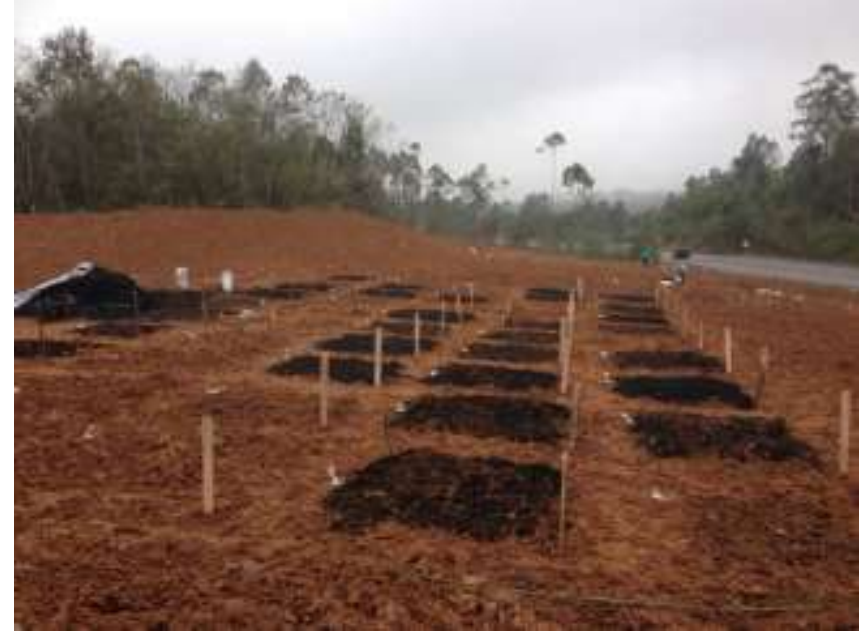




\subsubsection{Obtenção e caracterização do biossólido}

O biossólido utilizado nos experimentos foi coletado na Estação de Tratamento de Efluentes Industriais e Sanitários, da Empresa Rio Vivo Ambiental Ltda., localizada no município de Brusque/SC $\left(27^{\circ} 04^{\prime}\right.$ 25 " S e $48^{\circ} 53$ ' 29" W). Aproximadamente quatro toneladas de biossólido foram coletadas, apresentando teor de umidade reduzido de $80 \%$. Esse material foi transportado, utilizando-se um caminhão caçamba, até o município de Treviso/SC, e depositado em área experimental, pertencente à Carbonífera Metropolitana S/A (28 29' $14^{\prime \prime} \mathrm{S}$ e $49^{\circ} 27^{\prime} 40^{\prime}$ 'W). O biossólido foi depositado na área e coberto com lona plástica escura, permanecendo nestas condições por 08 dias. As análises químicas (Tabela 4) e microbiológicas do biossólido (Tabela 5) foram realizadas pelo Laboratório Biológico Ltda, localizado no município de Florianópolis/SC. A tabela 5 representa a quantificação de coliformes termotolerantes, ovos viáveis de helmintos, Salmonella e vírus entéricos presentes no biossólido.

\subsubsection{Condução e coleta do experimento}

Ao final do experimento (Figura 6), em 25 de outubro de 2016, 104 dias após a ressemeadura foram coletas amostras de solo das camadas $0-5,5-10$ e 10-20 $\mathrm{cm}$ de profundidade em cinco repetições, sorteadas aleatoriamente, dentro de cada tratamento (Figura 7). As amostras foram acondicionadas em sacos plásticos e encaminhadas ao laboratório de análise de solo, água e tecidos vegetais do departamento de Engenharia Rural da Universidade Federal de Santa Catarina (ENR/UFSC) para posteriores análises químicas do solo, e para o Laboratório de Diversidade Microbiana do Solo - DMS/MIP/UFSC para extração e contagem de fungos micorrízicos arbusculares (FMA) e obtenção da respiração basal do solo (RB). Parte das amostras foram secas ao ar, obtendo-se a terra fina seca ao ar (TFSA), e destinadas para a realização das análises de fertilidade e a outra parte foi armazenada em sacos plásticos a $4{ }^{\circ} \mathrm{C}$ até a realização das análises microbiológicas.

Na TFSA foram realizadas as seguintes análises químicas de caracterização do solo: $\mathrm{pH}$ em água, índice SMP, Al trocável (extraído por $\mathrm{KCl} 1 \mathrm{~mol} \mathrm{~L}^{-1}$ ), teores disponíveis de $\mathrm{P}$ e $\mathrm{K}$ (extraídos por Mehlich 1), conforme metodologia descrita por Tedesco et al. (1995). Os teores de P no extrato obtido foram determinados segundo Murphy \& Riley (1962), enquanto que os teores de $\mathrm{K}$ foram obtidos após leitura em 
fotômetro de chama. Com os valores do índice SMP obtidos, calculouse o teor de $\mathrm{H}+\mathrm{Al}$ conforme equação apresentada pela CQFS-RS/SC (2016). Para determinação do carbono orgânico total (COT), seguiu-se protocolo conforme orientações da Embrapa (1997), com adaptação para a utilização de bloco digestor.

No Laboratório de Diversidade Microbiana do Solo DMS/MIP/UFSC foram realizadas as análises microbiológicas do solo e do sistema radicular das plantas. O solo foi inicialmente peneirado em malha de 2,00 $\mathrm{mm}$ a fim de retirar materiais acima desta granulometria. Parte dele $(50 \mathrm{~mL})$ foi separada para extração e contagem de esporos de FMA, segundo metodologia descrita por Gerdemann e Nicolson (1963). Para determinar a respiração basal, amostras de solo de cada tratamento e em triplicata foram acondicionadas em recipientes com capacidade para $500 \mathrm{~mL}$, hermeticamente fechados, juntamente com um béquer de $50 \mathrm{~mL}$ contendo $20 \mathrm{~mL}$ de $\mathrm{NaOH} 0,05 \mathrm{~mol} \mathrm{~L}^{-1}$. Após um período de incubação de seis dias, o $\mathrm{NaOH}$ residual foi titulado com $\mathrm{HCl} \mathrm{0,05} \mathrm{mol}$ $\mathrm{L}^{-1}$, sendo o resultado expresso em mg C-CO $\mathrm{g}_{2}$ solo $\operatorname{seco}^{-1} \mathrm{~h}^{-1}$ (ISERMEYER, 1952). 
Tabela 4. Caracterização do biossólido coletado na estação de tratamento de esgoto da empresa Rio Vivo Ambiental, Brusque, Santa Catarina.

\begin{tabular}{lllll}
\hline Compostos/elementos & Teores $\left(\mathrm{mg} \mathrm{kg}^{-1}\right)$ & & Compostos/elementos & Teores $\left(\mathrm{mg} \mathrm{kg}^{-1}\right)$ \\
\cline { 1 - 2 } Arsênio & $<0,5$ & & Zinco & 570 \\
Bário & 120 & & Carbono orgânico & 87.000 \\
Cádmio & $<0,05$ & & Fósforo total & 6.400 \\
Chumbo & 10 & & Nitrogênio total & 14.200 \\
Cobre & 170 & & Potássio total & 900 \\
Cromo & 32 & Enxofre total & 1.100 \\
Mercúrio & $<0,5$ & Cálcio total & 2.300 \\
Molibdênio & 6 & Magnésio total & 1.100 \\
Níquel & 11 & pH em água & 6,86 \\
Selênio & 0,6 & - & - \\
\hline
\end{tabular}

Tabela 5. Quantificação dos patógenos existentes no biossólido da ETE pertencente à Rio Vivo Ambiental.

\begin{tabular}{lcccc}
\hline \multicolumn{1}{c}{ Análise microbiológica } & LQ & Unidade & Resultado & VMP \\
\hline Coliformes termotolerantes & $<1600$ & NMP/g de ST & $2,20 \times 10^{7}$ & $10^{3}$ \\
Ovos viáveis de helmintos & 0,25 & ovo/g de ST & $<0,25$ & 0,25 \\
Salmonella spp & 1 & NMP/10g & $<1$ & 10 \\
Vírus entéricos & 0,25 & UFP & $<0,25$ & 0,25 \\
\hline
\end{tabular}

Fonte: Relatório de ensaio 13241/13, Laboratório Biológico, 2013; LQ: Limite de Quantificação; NMP: Número Mais Provável; ST: Sólidos Totais; UFP: Unidade Formadora de Placa; VPM: Valor máximo permitido. 
Figura 6. Experimento a campo implantado em 13 de julho de 2017 (A). Aos 36 dias após implantação do experimento (B) e aos 104 dias após implantação (C).

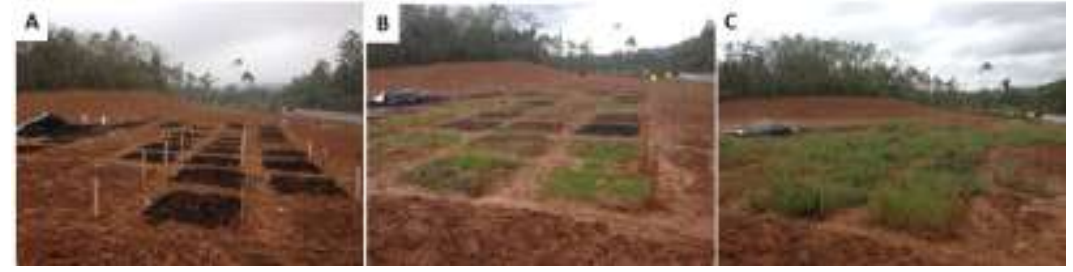

A parte aérea das plantas foi coletada no estágio de pleno florescimento em uma área útil de $0,25 \mathrm{~m}^{2}$, tomadas na parte central de cinco unidades experimentais, escolhidas ao acaso, em casa tratamento (Figura 8). As amostras foram armazenadas em sacos plásticos e transportadas até o laboratório de análise de solo, água e tecidos vegetais do ENR/UFSC e ao DMS/MIP/UFSC.

Nas amostras do material vegetal coletadas a campo realizou-se a separação da parte aérea e radicular das plantas. A parte área foi medida com auxílio de uma régua graduada de $30 \mathrm{~cm}$, e submetida à secagem em estufa de circulação de ar a $60^{\circ} \mathrm{C}$ por um período de oito dias, para determinação da matéria seca da parte aérea (MSPA).

A porção radicular foi lavada em água corrente sobre peneira de $0,5 \mathrm{~mm}$ de malha e $1 \mathrm{~g}$ de raízes finas foi coletado, armazenado em cápsulas e em solução de FAA (formalina-álcool-ácido acético) para posterior clarificação e coloração com azul de tripano (PHILLIPS; HAYMAN, 1970); procedimento utilizado para quantificação da taxa de colonização micorrízica, na qual as raízes são analisadas em estereoscópio através do método de interseção em placa quadriculada (GIOVANNETTI; MOSSE, 1980). O restante das raízes foi submetido à secagem em estufa sob as mesmas condições descritas para a secagem da parte aérea, a fim de se obter a matéria seca radicular (MSR).

A MSPA e a MSR de cada amostra foram quantificadas, utilizando balança analítica, após a secagem em estufa a $60^{\circ} \mathrm{C}$, até massa constante. $\mathrm{O}$ tecido vegetal seco foi triturado em moinho, em peneiras de $0,5 \mathrm{~mm}$, e determinaram-se os teores de fósforo e nitrogênio total conforme metodologia descrita por Tedesco et al. (1995). 
Figura 7. Coleta de amostras de solo das camadas 0-5, 5-10 e 10-20 cm de profundidade, em experimento em área impactada pela mineração de carvão no município de Treviso/SC. Trincheira com dimensões de $30 \times 30 \times 30 \mathrm{~cm}$ (a). Solo coletado com auxílio de uma pá e utilização de régua graduada para coleta das amostras correspondentes às profundidades (b). Fonte: Arquivo pessoal, 2016.
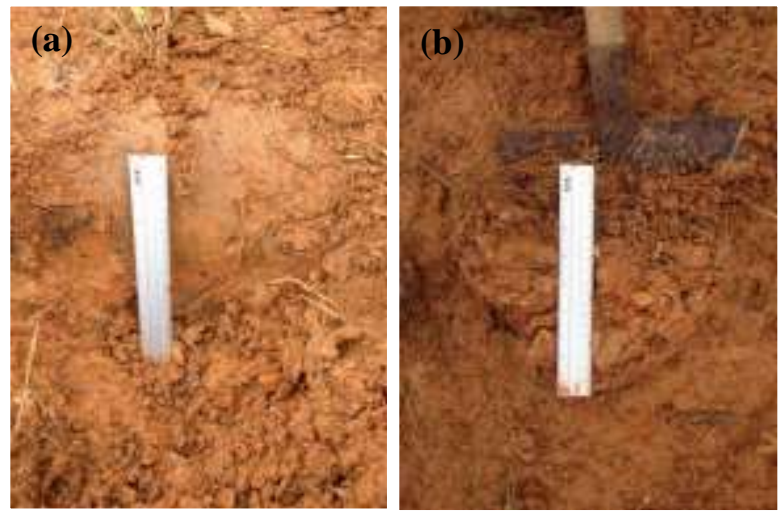

Figura 8. Utilização de quadrante de $0,25 \mathrm{~m}^{2}$ para coleta de material vegetal no meio das parcelas, em experimento a campo (a). Amostra de material vegetal (aveia preta, ervilhaca e azevém) coletado a campo (b). Fonte: Arquivo pessoal, 2016.
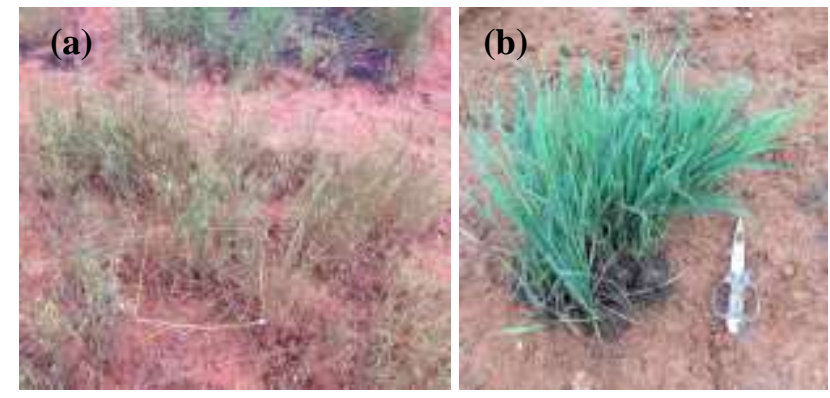

\subsection{Estudo 2 - Descrição da localização, condução, coleta e avaliação do experimento em casa de vegetação}

\subsubsection{Descrição da área experimental e tratamentos utilizados}

O experimento foi conduzido em casa de vegetação pertencente ao Grupo de Pesquisa em Microrganismos e Processos Biotecnológicos do Departamento de Microbiologia, Imunologia e Parasitologia 
(CCB/MIP/UFSC). O solo empregado nesse experimento foi coletado em área impactada pela mineração de carvão, localizada no município de Treviso/SC. Para o cultivo das espécies foram utilizados dois tipos de substrato base. O primeiro, composto de uma mistura de solo com presença de resíduos da extração do carvão (estéril) e biossólido. E o segundo, com o mesmo substrato base anteriormente citado, porém submetido à calagem para elevar o $\mathrm{pH}$ do solo a 6,0, conforme recomendação da CQFS-RS/SC (2016). Para a homogeneização do solo + biossólido + calcário, nos tratamentos com calagem, utilizou-se uma betoneira.

Para montagem do experimento, o solo foi peneirado (peneira de malha de 2,0 $\mathrm{mm}$ de diâmetro). Amostras de solo foram encaminhadas ao Laboratório de Solos da UFSC para análise de fertilidade, e uma porção de solo foi separada para contagem de esporos de FMA (GERDEMANN; NICOLSON, 1963), no Laboratório de Diversidade Microbiana do solo, MIP/UFSC.

Os tratamentos de biossólido avaliados referem-se às proporções: $0 \%$ (controle), 0,33\% (3,4 g), 25\% (287,5 g), 50\% (575 g) de biossólido, com correção do $\mathrm{pH}$ do solo e sem correção. O experimento foi desenvolvido entre agosto e outubro de 2016, utilizando-se vasos plásticos com capacidade de 1,2 L, dispostos em estande de grade.

A semeadura foi realizada no dia 03 de agosto de 2016. Para isso, foram retirados $100 \mathrm{~mL}$ de solo de cada vaso e a semeadura se deu pela deposição de um consórcio de sementes composto por 36 sementes de aveia preta, 10 sementes de ervilhaca e 60 sementes de azevém sobre o solo. Posteriormente, cobriu-se as sementes com os $100 \mathrm{~mL}$ de solo retirado anteriormente, a fim de evitar a exposição direta das sementes ao tempo. Adotou-se o delineamento fatorial 4x2 (quatro concentrações de biossólido e dois tratamentos com e sem calagem), sendo oito tratamentos, com 10 repetições, totalizando 80 vasos (Figura 9). Durante a realização do experimento procedeu-se a casualização da distribuição dos vasos a cada sete dias, para minimizar a variabilidade das condições da casa de vegetação. A umidade do solo em cada vaso foi mantida através de irrigações periódicas. As temperaturas máximas $\left(28^{\circ} \mathrm{C}\right)$ e mínimas $\left(11^{\circ} \mathrm{C}\right)$, bem como a umidade relativa do ar $(65 \%)$ foram monitoradas diariamente. A emergência das primeiras plantas se deu no terceiro dia após a semeadura. 


\subsubsection{Condução e coleta do experimento}

O experimento foi conduzido por um período de 69 dias. Ao final do experimento, as plantas foram medidas, com auxílio de trena graduada em $50 \mathrm{~cm}$, e a parte área foi separada da parte radicular (Figura 10), sendo então submetida à secagem em estufa de circulação de ar a $60^{\circ} \mathrm{C}$ por um período de quatro dias, a fim de se obter a matéria seca da parte aérea (MSPA).

Figura 9. Experimento em casa de vegetação, implantado em vasos plásticos sobre estande de grade, empregando delineamento fatorial $4 \times 2$. Fonte: Arquivo pessoal, 2016.

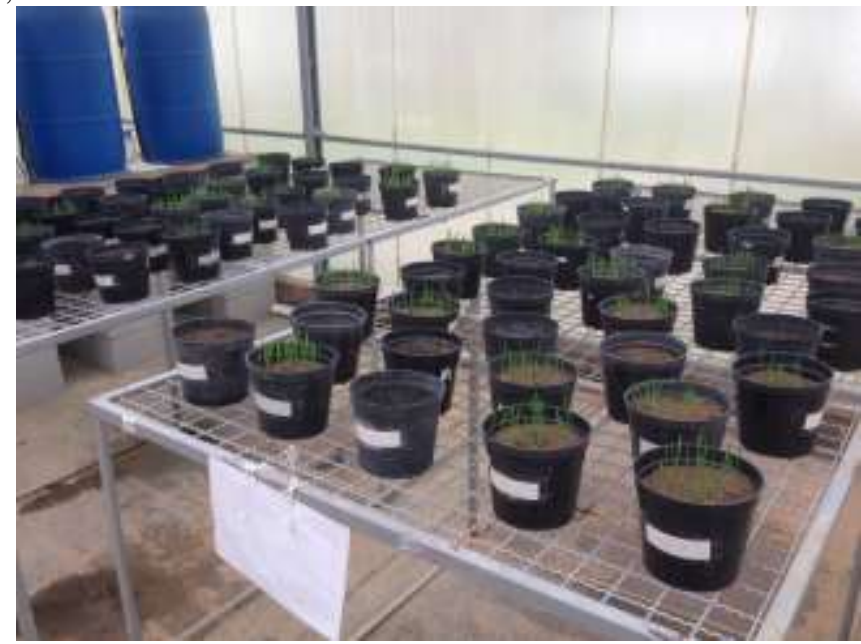

A porção radicular foi separa do solo e lavada em água corrente sobre peneira de $0,5 \mathrm{~mm}$ de malha e $1 \mathrm{~g}$ de raízes finas foi coletado, armazenado em cápsulas com solução de FAA (Formalina-álcool-ácido acético), seguindo os protocolos descritos por Phillips e Hayman (1970) e Giovannetti e Mosse (1980) para quantificação da taxa de colonização micorrízica nas raízes, anteriormente citados. O restante das raízes foi submetido à secagem em estufa a $60^{\circ} \mathrm{C}$ para determinação da matéria seca radicular (MSR).

Da mesma forma que no experimento a campo, a MSPA foi triturada em moinho para análise e determinação das concentrações de $\mathrm{P}$ e $\mathrm{N}$ total, conforme metodologia descrita por Tedesco et al. (1995). Ao final do experimento, amostras de solo de cada tratamento foram 
encaminhadas ao Laboratório de Solos da UFSC para avaliação dos atributos químicos do solo, semelhante ao descrito para o experimento a campo.

Figura 10. Separação da parte área e da parte radicular de aveia preta, em experimento utilizando solo de área de mineração + biossólido (a). Raízes de aveia, ervilhaca e azevém no solo cultivado em casa de vegetação com adição de biossólido (b). Fonte: Arquivo pessoal, 2016.
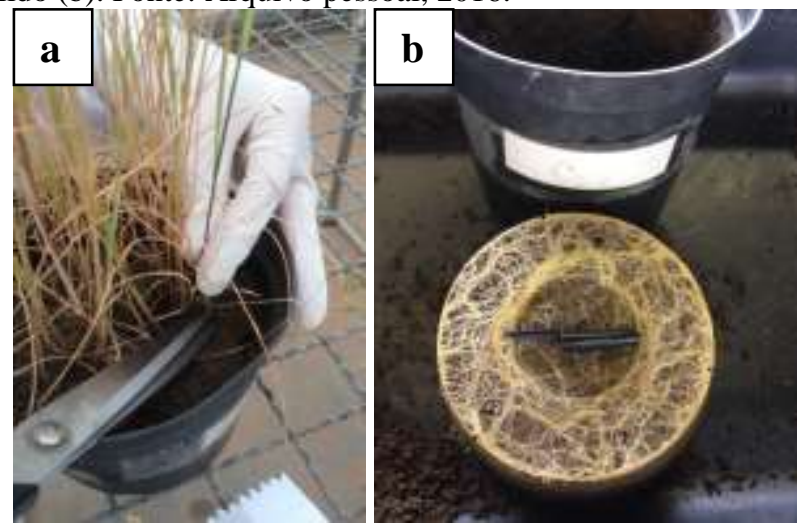

\subsection{Análises estatísticas}

Foram avaliados os efeitos dos tratamentos sobre altura das plantas $(\mathrm{cm})$, produção de matéria seca da parte aérea, produção de matéria seca de raiz, teor de $\mathrm{N}$ na parte aérea, teor de $\mathrm{P}$ na parte aérea, colonização radicular por BFN, colonização micorrízica, esporulação de FMA, atributos químicos do solo e respiração basal do solo (pré e pós tratamento).

Os dados obtidos foram submetidos à análise de variância e as médias foram comparadas pelo teste de Scott-Knott a 5\% de probabilidade. Para isso, foi utilizado o programa estatístico SISVAR (Ferreira, 2011) e o programa SigmaPlot 12 (Systat Software Corp.). Os resultados obtidos para colonização micorrízica antes de serem submetidos à análise de variância foram normalizados pela transformação arcsen raiz (\% colonização/100). E as transformações para número de esporos foram $(\mathrm{x}+0,5)^{\wedge} 1 / 2$. 


\section{RESULTADOS}

\subsection{Estudo 1 - Efeito do biossólido nos atributos químicos do solo em experimento a campo}

A aplicação do biossólido não promoveu alteração nos valores de $\mathrm{pH}$ do solo em nenhuma das profundidades avaliadas. Entretanto, cabe ressaltar que os maiores valores de $\mathrm{pH}$ foram observados na camada 0-5 $\mathrm{cm}$, diminuindo com o aumento da profundidade nos tratamentos que receberam aplicação de biossólido nas doses de 100 e $250 \mathrm{Mg} \mathrm{ha}^{-1}$ (Tabela 6).

A acidez potencial $(\mathrm{H}+\mathrm{Al})$ do solo diminuiu com a aplicação de biossólido na camada mais superficial e aumentou na camada $10-20 \mathrm{~cm}$, sendo os maiores valores obtidos no tratamento com $500 \mathrm{Mg} \mathrm{ha}^{-1} \mathrm{de}$ biossólido (Tabela 6). Considerando a camada $0-5 \mathrm{~cm}$, as reduções percentuais na acidez potencial do solo foram de 27, 61, 55 e 92\% para os tratamentos 6,$25 ; 100,250$ e $500 \mathrm{Mg} \mathrm{ha}^{-1}$, respectivamente, quando comparados ao tratamento controle. Os tratamentos com doses de 100, 200 e $500 \mathrm{Mg} \mathrm{ha}^{-1}$ de biossólido apresentaram diferenças significativas entre as profundidades avaliadas, sendo os maiores valores obtidos na camada $10-20 \mathrm{~cm}$.

$\mathrm{O}$ uso do biossólido promoveu redução nos teores de $\mathrm{Al}$ até a profundidade de $5 \mathrm{~cm}$, no tratamento com $100 \mathrm{Mg} \mathrm{ha}^{-1}$, e até $10 \mathrm{~cm}$ nos tratamentos com 250 e $500 \mathrm{Mg} \mathrm{ha}^{-1}$, quando comparados com os tratamentos controle e $6,25 \mathrm{Mg} \mathrm{ha}^{-1}$ (Tabela 6). Na camada 0-5 cm, a redução nos teores de $\mathrm{Al}$ foi de 35,42 e $55 \%$ para os tratamentos com 100, 250 e $500 \mathrm{Mg} \mathrm{ha}^{-1}$ de biossólido, quando comparados ao controle.

Com relação aos teores de $\mathrm{P}$, os tratamentos que receberam aplicação de biossólido apresentaram maiores teores de $\mathrm{P}$, especialmente na camada $0-5 \mathrm{~cm}$, onde os maiores valores foram observados no tratamento com $500 \mathrm{Mg} \mathrm{ha}^{-1}$ de biossólido, representando incremento de 13 vezes em relação ao controle (Tabela 6). Cabe ressaltar que nas profundidades 5-10 e 10-20 $\mathrm{cm}$ os maiores teores de $\mathrm{P}$ foram encontrados no tratamento com 6,25 $\mathrm{Mg} \mathrm{ha}^{-1}$ de biossólido.

Para os teores de $\mathrm{K}$, apenas o tratamento com uso de $500 \mathrm{Mg}$ $\mathrm{ha}^{-1}$ de biossólido apresentou incrementos nos teores na camada $0-5 \mathrm{~cm}$, enquanto que o tratamento $6,25 \mathrm{Mg} \mathrm{ha}^{-1}$ apresentou teores menores aos observados no tratamento controle (Tabela 6). Para as demais profundidades, os tratamentos controle e $500 \mathrm{Mg} \mathrm{ha}^{-1}$ apresentaram teores semelhantes, enquanto que os demais tratamentos apresentaram 
menores teores de $\mathrm{K}$, com exceção da camada $5-10 \mathrm{~cm}$ do tratamento $250 \mathrm{Mg} \mathrm{ha}^{-1}$.

Tabela 6. Atributos químicos de solo degradado pela mineração de carvão com adição de diferentes concentrações de biossólido, Carbonífera Metropolitana, Treviso/ SC.

\begin{tabular}{|c|c|c|c|c|c|c|}
\hline \multirow{2}{*}{ Prof., cm } & \multicolumn{5}{|c|}{ Biossólido, $\mathrm{Mg} \mathrm{ha}^{-1}$} & \multirow{2}{*}{$\mathrm{CV}, \%$} \\
\hline & 0 & 6,25 & 100 & 250 & 500 & \\
\hline & \multicolumn{5}{|c|}{$\mathrm{pH}$} & \multirow[b]{2}{*}{7,14} \\
\hline $0-5$ & $4,15^{\mathrm{ns}} \mathrm{A}$ & $4,06{ }^{\mathrm{ns}} \mathrm{A}$ & $4,37 \mathrm{aA}$ & $4,52 \mathrm{aA}$ & $4,46^{\mathrm{ns}} \mathrm{A}$ & \\
\hline $5-10$ & $3,99 \mathrm{~A}$ & $4,17 \mathrm{~A}$ & $4,00 \mathrm{bA}$ & $4,25 \mathrm{bA}$ & $4,16 \mathrm{~A}$ & 3,72 \\
\hline $10-20$ & $3,86 \mathrm{~A}$ & $4,07 \mathrm{~A}$ & $3,93 \mathrm{bA}$ & $3,85 \mathrm{cA}$ & $3,96 \mathrm{~A}$ & 6,15 \\
\hline $\mathrm{CV}, \%$ & 5,15 & 4,22 & 4,62 & 4,14 & 9,41 & \\
\hline \multicolumn{6}{|c|}{$\mathrm{H}+\mathrm{Al}, \mathrm{cmol}_{\mathrm{c}} \mathrm{dm}^{-3}$} & \multirow[b]{2}{*}{12,18} \\
\hline $0-5$ & $83,43^{\mathrm{ns}} \mathrm{A}$ & $60,67^{\mathrm{ns}} \mathrm{B}$ & $32,65 \mathrm{bC}$ & $37,22 \mathrm{cC}$ & $6,73 \mathrm{cD}$ & \\
\hline $5-10$ & $76,67 \mathrm{~A}$ & $64,27 \mathrm{~B}$ & $82,68 \mathrm{aA}$ & $68,35 \mathrm{bB}$ & $66,61 \mathrm{bB}$ & 9,98 \\
\hline $10-20$ & $85,95 \mathrm{~B}$ & $66,41 \mathrm{C}$ & $86,74 \mathrm{aB}$ & $85,46 \mathrm{aB}$ & $98,24 \mathrm{aA}$ & 6,20 \\
\hline $\mathrm{CV}, \%$ & 6,75 & 8,34 & 11,69 & 10,14 & 7,18 & \\
\hline \multicolumn{6}{|c|}{$\mathrm{Al}, \mathrm{cmol}_{\mathrm{c}} \mathrm{dm}^{-3}$} & \multirow{5}{*}{$\begin{array}{l}25,14 \\
14,30 \\
11,81\end{array}$} \\
\hline $0-5$ & $8,44 \mathrm{bA}$ & $8,06 \mathrm{bA}$ & $5,45 \mathrm{bB}$ & $4,85 \mathrm{cB}$ & $3,77 \mathrm{bB}$ & \\
\hline $5-10$ & $8,62 \mathrm{bA}$ & $9,30 \mathrm{aA}$ & $8,23 \mathrm{aA}$ & $6,97 \mathrm{bB}$ & $6,46 \mathrm{aB}$ & \\
\hline $10-20$ & $9,72 \mathrm{aA}$ & $9,03 \mathrm{aA}$ & $8,87 \mathrm{aA}$ & $9,65 \mathrm{aA}$ & $8,75 \mathrm{aA}$ & \\
\hline $\mathrm{CV}, \%$ & 9,52 & 8,38 & 9,70 & 14,69 & 35,84 & \\
\hline \multicolumn{6}{|c|}{$\mathrm{P}, \mathrm{mg} \mathrm{kg}^{-1}$} & \multirow{5}{*}{$\begin{array}{l}59,99 \\
16,12 \\
24,73\end{array}$} \\
\hline $0-5$ & $2,36 \mathrm{aB}$ & $14,64^{\mathrm{ns}} B$ & $7,30 \mathrm{aB}$ & $16,84 \mathrm{aB}$ & $31,59 \mathrm{aA}$ & \\
\hline $5-10$ & $1,16 \mathrm{aD}$ & $14,84 \mathrm{~A}$ & $2,55 \mathrm{bC}$ & $3,41 \mathrm{bC}$ & $11,50 \mathrm{bB}$ & \\
\hline $10-20$ & $2,42 \mathrm{aB}$ & $15,05 \mathrm{~A}$ & $1,33 \mathrm{bB}$ & $2,24 \mathrm{bB}$ & $3,28 \mathrm{bB}$ & \\
\hline $\mathrm{CV}, \%$ & 50,33 & 6,48 & 64,00 & 27,00 & 59,84 & \\
\hline \multicolumn{6}{|c|}{$\mathrm{K}, \mathrm{mg} \mathrm{kg}^{-1}$} & \multirow{5}{*}{$\begin{array}{l}28,69 \\
20,75 \\
31,78\end{array}$} \\
\hline $0-5$ & $34,75 \mathrm{aB}$ & $19,25 \mathrm{aC}$ & $36,75 \mathrm{aB}$ & $34,40 \mathrm{aB}$ & $49,25 \mathrm{aA}$ & \\
\hline $5-10$ & $21,20 \mathrm{bA}$ & $14,20 \mathrm{bB}$ & $13,80 \mathrm{bB}$ & $20,00 \mathrm{bA}$ & $25,25 \mathrm{bA}$ & \\
\hline $10-20$ & $22,25 \mathrm{bA}$ & $14,25 \mathrm{bB}$ & $13,25 \mathrm{bB}$ & $14,40 \mathrm{bB}$ & $16,25 \mathrm{bA}$ & \\
\hline $\mathrm{CV}, \%$ & 21,54 & 16,27 & 39,54 & 18,00 & 31,28 & \\
\hline \multicolumn{6}{|c|}{ COT, $\mathrm{g} \mathrm{kg}^{-1}$} & \multirow{5}{*}{$\begin{array}{l}22,21 \\
31,75 \\
27,30\end{array}$} \\
\hline $0-5$ & $12,47 \mathrm{aA}$ & $19,63 \mathrm{aA}$ & $16,51 \mathrm{aA}$ & $16,01{ }^{\mathrm{ns}} \mathrm{A}$ & $19,52{ }^{\mathrm{ns}} \mathrm{A}$ & \\
\hline $5-10$ & $8,77 \mathrm{bB}$ & $13,81 \mathrm{bB}$ & $10,41 \mathrm{bB}$ & $10,76 \mathrm{~B}$ & $20,46 \mathrm{~A}$ & \\
\hline $10-20$ & $13,83 \mathrm{aB}$ & $14,07 \mathrm{bB}$ & $12,30 \mathrm{bB}$ & $13,89 \mathrm{~B}$ & $21,60 \mathrm{~A}$ & \\
\hline $\mathrm{CV}, \%$ & 23,57 & 22,86 & 26,07 & 28,88 & 27,48 & \\
\hline
\end{tabular}

*Médias seguidas de mesma letra não diferem estatisticamente entre si, maiúscula na linha e minúscula na coluna, pelo teste de Scott-Knott a $5 \%$ de probabilidade de erro; ns: não significativo.

Em relação ao COT, o uso do biossólido não promoveu efeito nos teores da camada $0-5 \mathrm{~cm}$, enquanto que nas demais camadas o tratamento $500 \mathrm{Mg} \mathrm{ha}^{-1}$ apresentou maiores teores de COT em relação aos demais tratamentos, os quais não diferiram entre si (Tabela 6). 


\subsection{Estudo 1 - Efeito do biossólido no crescimento de aveia preta, ervilhaca e azevém consorciadas em experimento a campo}

Para o parâmetro altura, observou-se que os tratamentos que receberam as doses de 6,25; 100 e $500 \mathrm{Mg} \mathrm{ha}^{-1}$ de biossólido incorporado ao solo apresentaram os melhores resultados quando comparados ao controle, que não diferiu do tratamento com $250 \mathrm{Mg} \mathrm{ha}^{-1}$ de biossólido (Figura 11a). Os maiores incrementos na altura das plantas foram observados com aplicação de $100 \mathrm{Mg} \mathrm{ha}^{-1}$ de biossólido, com acréscimo de 4,2 vezes em relação ao tratamento controle.

Figura 11. Altura média das plantas (a), matéria seca da parte aérea (b) e matéria seca radicular (c) do consórcio aveia preta, ervilhaca e azevém cultivados a campo em solo degradado pela mineração de carvão com adição de diferentes concentrações de biossólido. Barras verticais representam o desvio padrão da média $(n=5)$. Médias seguidas da mesma letra não diferem entre si pelo teste de Scott-Knott (1974) a 5\% de probabilidade de erro.
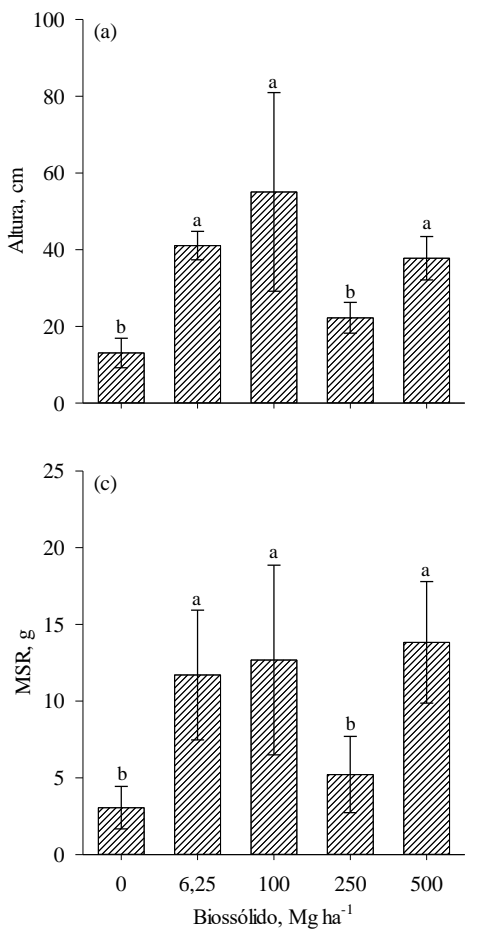

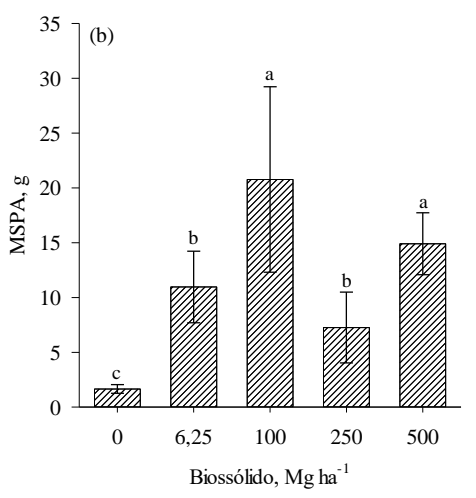


Com relação aos valores de matéria seca da parte aérea (MSPA), a aplicação de biossólido incrementou a produção de MSPA do consórcio avaliado, sendo que os tratamentos com 100 e $500 \mathrm{Mg} \mathrm{ha}^{-1}$ apresentaram os melhores resultados (Figura 11b). Os tratamentos com 6,25 e $250 \mathrm{Mg} \mathrm{ha}^{-1}$ de biossólido apresentaram resultados semelhantes, sendo superiores ao controle. Para os tratamentos 100 e $500 \mathrm{Mg} \mathrm{ha}^{-1} \mathrm{de}$ biossólido os incrementos na produção de MSPA foram de 12,5 e 9,0 vezes em relação ao tratamento controle.

A matéria seca radicular (MSR) apresentou diferenças entre os tratamentos avaliados, sendo que os tratamentos com 6,25; 100 e 500 $\mathrm{Mg} \mathrm{ha}^{-1}$ apresentaram os maiores valores de MSR, enquanto que o uso de $250 \mathrm{Mg} \mathrm{ha}^{-1}$ de biossólido não diferiu do tratamento controle (Figura 11c). Os incrementos na produção de MSR foram de 3,8; 4,2 e 4,5 vezes em relação ao tratamento controle.

\subsection{Estudo 1 - Efeito do biossólido no teor de nitrogênio e fósforo da parte área das plantas consorciadas em experimento a campo}

Os resultados da determinação dos teores de $\mathrm{N}$ e $\mathrm{P}$ da parte aérea das plantas indicaram que o consórcio de aveia preta, ervilhaca e azevém é influenciado pelas concentrações de biossólido quando incorporadas ao solo. À medida que aumentou a proporção de biossólido no substrato aumentaram também os teores de $\mathrm{N}$ e $\mathrm{P}$ na parte aérea das plantas (Figura 12a e 12b).

Os tratamentos com 250 e $500 \mathrm{Mg} \mathrm{ha}^{-1}$ de biossólido foram os que apresentaram maior incremento nos teores de $\mathrm{N}$ na parte aérea das plantas, com incrementos de 106 e $92 \%$, respectivamente, em relação ao tratamento controle. Os tratamentos controle e $100 \mathrm{Mg} \mathrm{ha}^{-1}$ de biossólido não apresentaram diferença entre si (Figura 12a). Para o teor de $\mathrm{P}$ na parte aérea os tratamentos 100 e $250 \mathrm{Mg} \mathrm{ha}^{-1}$ de biossólido foram os que apresentaram maior incremento, representando $142 \mathrm{e}$ $193 \%$, respectivamente, em relação ao controle. Os tratamentos controle, 6,25 e $500 \mathrm{Mg} \mathrm{ha}^{-1}$ de biossólido foram semelhantes quanto ao teor de P na parte aérea (Figura 12b).

Figura 12. Teores de $\mathrm{N}$ (a) e P (b) em consórcio de aveia preta, ervilhaca e azevém cultivados a campo em solo degradado pela mineração de carvão com adição de diferentes concentrações de biossólido. Barras verticais representam o 
desvio padrão da média ( $\mathrm{n}=5$ ). Médias seguidas da mesma letra não diferem entre si pelo teste de Scott-Knott (1974) a 5\% de probabilidade de erro.
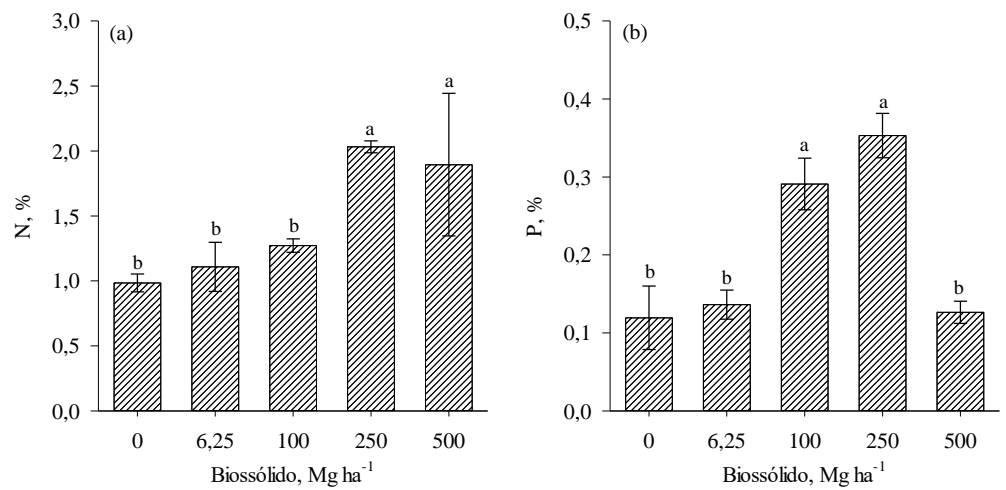

\subsection{Estudo 1 - Efeito do biossólido na colonização micorrízica, esporulação e respiração basal do solo em experimento a campo}

Os resultados referentes à colonização micorrízica (Figura 13a), esporulação (Figura 13b) e respiração basal (Figura 13c) demonstraram que a adição de diferentes doses de biossólido no solo não influenciaram significativamente esses parâmetros. Por outro lado, os valores da contagem de esporos do solo pré-experimento e pós-experimento indicaram que a adição de biossólido promoveu um decréscimo médio de $42 \%$ em relação ao número médio de esporos presentes no solo antes da aplicação dos tratamentos, sugerindo que o biossólido possui influências negativas para essa variável (Figura 13a).

A respiração basal do solo possibilita estabelecer uma relação direta entre a respiração basal e o aporte de carbono que está sendo adicionado ao sistema. Os resultados obtidos no experimento demonstraram que a respiração basal não mostrou diferenças nos cinco tratamentos, não havendo, portanto, efeitos do biossólido sobre os tratamentos avaliados (Figura 13c).

Figura 13. Número de esporos (a), colonização micorrízica (b) e respiração basal (c) nas raízes de aveia preta, ervilhaca e azevém cultivados a campo em solo degradado pela mineração de carvão com adição de diferentes 
concentrações de biossólido. Barras verticais representam o desvio padrão da média $(n=5)$. Linha tracejada representa a média do número de esporos (a) e respiração basal (c) antes da aplicação do biossólido $(\mathrm{n}=5)$. Médias seguidas da mesma letra não diferem entre si pelo teste de Scott-Knott (1974) a 5\% de probabilidade de erro.
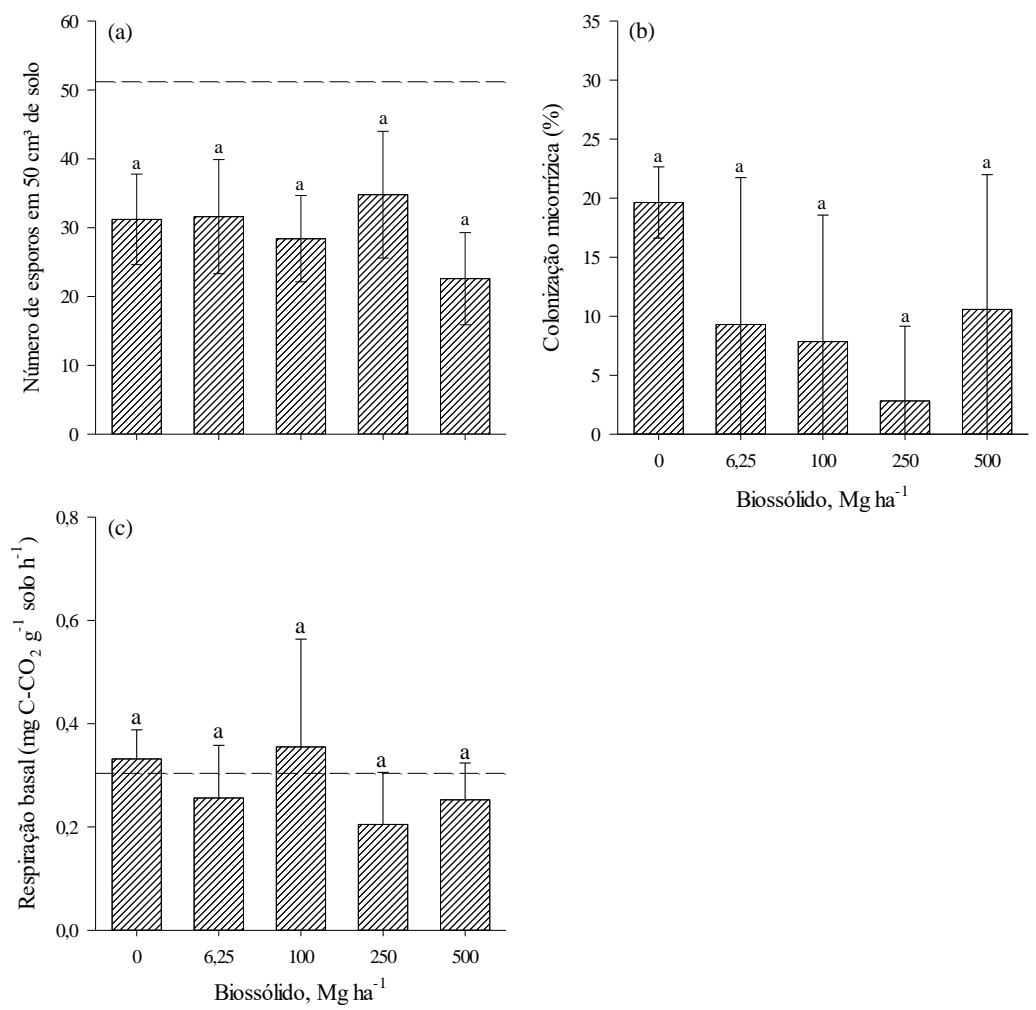

\subsection{Estudo 1 - Efeito do biossólido na nodulação radicular}

A avaliação do sistema radicular do consórcio de plantas estudado revelou a ausência de nódulos de rizóbio em todos os tratamentos com e sem a aplicação do biossólido. 


\subsection{Estudo 2 - Efeito do biossólido nos atributos químicos do solo em experimento em casa de vegetação}

A aplicação do biossólido promoveu aumento nos valores de $\mathrm{pH}$ do solo nos tratamentos 250 e $500 \mathrm{Mg} \mathrm{ha}^{-1}$, sendo observado o mesmo comportamento, tanto para o tratamento com calagem quanto para o sem calagem (Tabela 7). Os maiores valores de $\mathrm{pH}$ do solo foram obtidos nos tratamentos com $500 \mathrm{Mg} \mathrm{ha}^{-1}$ de biossólido. Por outro lado, os tratamentos controle e $6,25 \mathrm{Mg} \mathrm{ha}^{-1}$ de biossólido com calagem apresentaram maiores valores de $\mathrm{pH}$ quando comparados aos mesmos tratamentos sem calagem. $\mathrm{O}$ que se verificou, no entanto, é que mesmo sem a calagem, os tratamentos com 250 e $500 \mathrm{Mg} \mathrm{ha}^{-1}$ de biossólido promoveram elevação do $\mathrm{pH}$ do solo para valores acima dos preconizados pela CQFS-RS/SC (2016) para o cultivo do consórcio utilizado, indicando eficiência na correção da acidez do solo nas condições utilizadas na condução do experimento.

A acidez potencial $(\mathrm{H}+\mathrm{Al})$ do solo diminuiu nos tratamentos com e sem calagem com aplicação de biossólido (Tabela 7). Considerando o tratamento sem calagem, os maiores valores foram obtidos nos tratamentos controle e $6,25 \mathrm{Mg} \mathrm{ha}^{-1}$ de biossólido, sendo que os mesmos não diferiram. Os tratamentos controle e $6,25 \mathrm{Mg} \mathrm{ha}^{-1} \mathrm{de}$ biossólido com calagem apresentaram uma redução de $94 \%$ na acidez potencial do solo quando comparados aos tratamentos de mesma dose de biossólido, porém sem a calagem (Tabela 7).

$\mathrm{O}$ uso do biossólido promoveu redução nos teores de $\mathrm{Al}$ nos tratamentos com doses de 250 e $500 \mathrm{Mg} \mathrm{ha}^{-1}$ de biossólido quando utilizados sem calagem, sendo os maiores valores obtidos no tratamento controle (Tabela 7). Para os tratamentos com calagem, houve uma redução nos teores de $\mathrm{Al}$ quando comparados aos tratamentos sem calagem, sendo observada redução de $96 \%$ nos teores de $\mathrm{Al}$ dos tratamentos controle sem calagem e com calagem.

Com relação aos teores de $\mathrm{P}$, os tratamentos que receberam aplicação de biossólido apresentaram maiores teores de $\mathrm{P}$, sendo que os maiores valores foram observados nos tratamentos com $500 \mathrm{Mg} \mathrm{ha}^{-1} \mathrm{de}$ biossólido sem e com calagem, representando incremento de 14 e 13 vezes em relação aos controles, respectivamente (Tabela 7). Cabe ressaltar que com exceção do tratamento com $6,25 \mathrm{Mg} \mathrm{ha}^{-1}$ de biossólido, que apresentou aumento de 04 vezes nos teores de $\mathrm{P}$ proporcionados pela calagem, os demais tratamentos não apresentaram 
variações nos teores de $\mathrm{P}$ entre os tratamentos com e sem calagem para todas as doses de biossólido avaliadas.

Tabela 7. Atributos químicos do solo coletado em área degradada pela mineração de carvão com presença de estéril de mineração, Carbonífera Metropolitana, Treviso/SC. Resultados obtidos em experimento conduzido em casa de vegetação, utilizando solo com calagem e sem calagem, e quatro tratamentos com doses diferentes de biossólido.

\begin{tabular}{|c|c|c|c|c|c|}
\hline \multirow{2}{*}{ Calagem } & \multicolumn{4}{|c|}{ Biossólido, $\mathrm{Mg} \mathrm{ha}^{-1}$} & \multirow{2}{*}{$\begin{array}{c}\mathrm{CV}, \\
\%\end{array}$} \\
\hline & 0 & 6,25 & 250 & 500 & \\
\hline & \multicolumn{4}{|c|}{$\mathrm{pH}$} & \multirow{4}{*}{$\begin{array}{l}2,34 \\
2,72\end{array}$} \\
\hline Sem & $3,49 \mathrm{bC}$ & $3,64 \mathrm{bC}$ & $7,10{ }^{\mathrm{ns}} \mathrm{B}$ & $7,48^{\mathrm{ns}} \mathrm{A}$ & \\
\hline Com & $5,16 \mathrm{aC}$ & $5,18 \mathrm{aC}$ & 7,06 B & $7,38 \mathrm{~A}$ & \\
\hline \multirow[t]{2}{*}{$\mathrm{CV}, \%$} & 3,99 & 3,80 & 1,79 & 1,66 & \\
\hline & \multicolumn{4}{|c|}{$\mathrm{H}+\mathrm{Al}, \mathrm{cmol}_{\mathrm{c}} \mathrm{dm}^{-3}$} & \multirow{4}{*}{$\begin{array}{l}11,06 \\
22,93\end{array}$} \\
\hline Sem & $69,89 \mathrm{aA}$ & $65,48 \mathrm{aA}$ & $1,96{ }^{\mathrm{ns}} \mathrm{B}$ & $1,87 \mathrm{aB}$ & \\
\hline Com & $4,52 \mathrm{bA}$ & $4,17 \mathrm{bA}$ & $1,43 \mathrm{~B}$ & $1,59 \mathrm{bB}$ & \\
\hline \multirow[t]{2}{*}{$\mathrm{CV}, \%$} & 2,60 & 15,57 & 24,68 & 10,67 & \\
\hline & \multicolumn{4}{|c|}{$\mathrm{Al}, \mathrm{cmol}_{\mathrm{c}} \mathrm{dm}^{-3}$} & \multirow{4}{*}{$\begin{array}{l}15,96 \\
37,01\end{array}$} \\
\hline Sem & $11,12 \mathrm{aA}$ & $10,24 \mathrm{aA}$ & $0,64{ }^{\mathrm{ns}} \mathrm{B}$ & $0,40 \mathrm{bB}$ & \\
\hline Com & $0,48 \mathrm{bA}$ & $0,09 \mathrm{bB}$ & $0,37 \mathrm{~A}$ & $0,53 \mathrm{aA}$ & \\
\hline \multirow[t]{2}{*}{$\mathrm{CV}, \%$} & 7,76 & 22,21 & 65,86 & 16,66 & \\
\hline & \multicolumn{4}{|c|}{$\mathrm{P}, \mathrm{mg} \mathrm{kg}^{-1}$} & \multirow{4}{*}{$\begin{array}{l}23,01 \\
49,19\end{array}$} \\
\hline Sem & $1,16{ }^{\mathrm{ns}} \mathrm{C}$ & $2,26 \mathrm{bC}$ & $9,51^{\mathrm{ns}} \mathrm{B}$ & $16,23{ }^{\mathrm{ns}} \mathrm{A}$ & \\
\hline Com & $1,34 \mathrm{~B}$ & $8,82 \mathrm{aB}$ & $12,36 \mathrm{~A}$ & $18,00 \mathrm{~A}$ & \\
\hline \multirow[t]{2}{*}{$\mathrm{CV}, \%$} & 46,99 & 67,76 & 57,56 & 10,73 & \\
\hline & \multicolumn{4}{|c|}{$\mathrm{K}, \mathrm{mg} \mathrm{kg}^{-1}$} & \multirow[b]{2}{*}{11,93} \\
\hline Sem & $19,00 \mathrm{bC}$ & $19,20{ }^{\mathrm{ns}} \mathrm{C}$ & $112,14^{\mathrm{ns}} B$ & $\begin{array}{c}206,80 \\
{ }^{\mathrm{ns}} \mathrm{A}\end{array}$ & \\
\hline Com & $22,40 \mathrm{aC}$ & $24,00 \mathrm{C}$ & $123,40 \mathrm{~B}$ & $195,20 \mathrm{~A}$ & 35,29 \\
\hline \multirow[t]{2}{*}{$\mathrm{CV}, \%$} & 6,21 & 51,53 & 36,71 & 8,65 & \\
\hline & \multicolumn{4}{|c|}{ COT, $\mathrm{g} \mathrm{kg}^{-1}$} & \\
\hline Sem & $21,08^{\mathrm{ns}} \mathrm{A}$ & $21,04{ }^{\mathrm{ns}} \mathrm{A}$ & $13,73 \mathrm{bB}$ & $14,38 \mathrm{bB}$ & 11,66 \\
\hline Com & $22,78 \mathrm{~B}$ & $23,17 \mathrm{~B}$ & $28,97 \mathrm{aA}$ & $28,58 \mathrm{aA}$ & 4,18 \\
\hline $\mathrm{CV}, \%$ & 6,72 & 12,49 & 1,96 & 4,05 & \\
\hline
\end{tabular}

*Médias seguidas de mesma letra não diferem estatisticamente entre si, maiúscula na linha e minúscula na coluna, pelo teste de Scott-Knott a 5\% de probabilidade. 
Para os teores de K, o uso do biossólido promoveu incremento nos teores de $\mathrm{K}$ presentes no solo. Os tratamentos sem e com calagem responderam de forma semelhante para todas as doses avaliadas, sendo os tratamentos com $500 \mathrm{Mg} \mathrm{ha}^{-1}$ de biossólido os que proporcionaram maiores valores nos teores de $\mathrm{K}$, com incremento de 11 e 09 vezes em relação aos controles sem e com calagem, respectivamente (Tabela 7). Com exceção do tratamento controle, a calagem não promoveu efeito entre os tratamentos.

As diferentes concentrações de biossólido promoveram incrementos nos teores de COT nos tratamentos com calagem e houve redução nos tratamentos sem calagem (Tabela 7). Enquanto que para os tratamentos sem calagem os maiores teores de COT foram observados nos tratamentos controle e $6,25 \mathrm{Mg} \mathrm{ha}^{-1}$, com a realização da calagem os maiores teores de COT foram observados com o uso de 250 e $500 \mathrm{Mg}$ ha $^{-1}$ de biossólido.

\subsection{Estudo 2 - Efeito do biossólido no crescimento de aveia preta, ervilhaca e azevém consorciadas em experimento em casa de vegetação}

Os tratamentos com as concentrações elevadas de biossólido (250 e $500 \mathrm{Mg} \mathrm{ha}^{-1}$ ) promoveram elevadas perdas da biomassa vegetal testada. As concentrações superiores a $6,25 \mathrm{Mg} \mathrm{ha}^{-1}$ de biossólido no substrato ocasionaram taxa de mortalidade de $100 \%$ para o consórcio de plantas, e por essa razão são apresentados apenas os resultados dos tratamentos controle e $6,25 \mathrm{Mg} \mathrm{ha}^{-1}$ de biossólido (Figuras 14a, 14b e 14c).

Para os parâmetros altura, MSPA e MSR foram observadas diferenças entre os tratamentos controle, com e sem calagem, sendo que os maiores valores para os parâmetros avaliados foram observados com a aplicação da calagem. No entanto, quando do uso de $6,25 \mathrm{Mg} \mathrm{ha}^{-1}$ de biossólido, apenas a MSPA apresentou maiores valores quando do uso da calagem, sendo que não houve diferença na altura das plantas e para a MSR os maiores valores foram observados quando do uso do biossólido sem calagem (Figuras 14a, 14b, 14c).

Para todos os parâmetros analisados (altura, MSPA, MSR), quando da realização da calagem, não foram observadas diferenças entre o tratamento controle e com uso de $6,25 \mathrm{Mg} \mathrm{ha}^{-1}$ de biossólido. Entretanto, quando não foi realizada a calagem, o tratamento com 6,25 
$\mathrm{Mg} \mathrm{ha}^{-1}$ de biossólido apresentou incrementos de $63 \%$ na altura média das plantas, $85 \%$ na MSPA e $272 \%$ na MSR.

Figura 14. Altura das plantas (a), matéria seca da parte aérea (b) matéria seca radicular (c) em substrato de área de mineração, sem e com calagem, submetido à aplicação de diferentes doses de biossólido. Barras verticais representam o desvio padrão da média $(\mathrm{n}=10)$. Médias seguidas da mesma letra, minúscula entre as doses de biossólido e maiúscula comparando o efeito da calagem na mesma dose de biossólido, não diferem entre si pelo teste de Scott-Knott (1974) a $5 \%$ de probabilidade de erro.
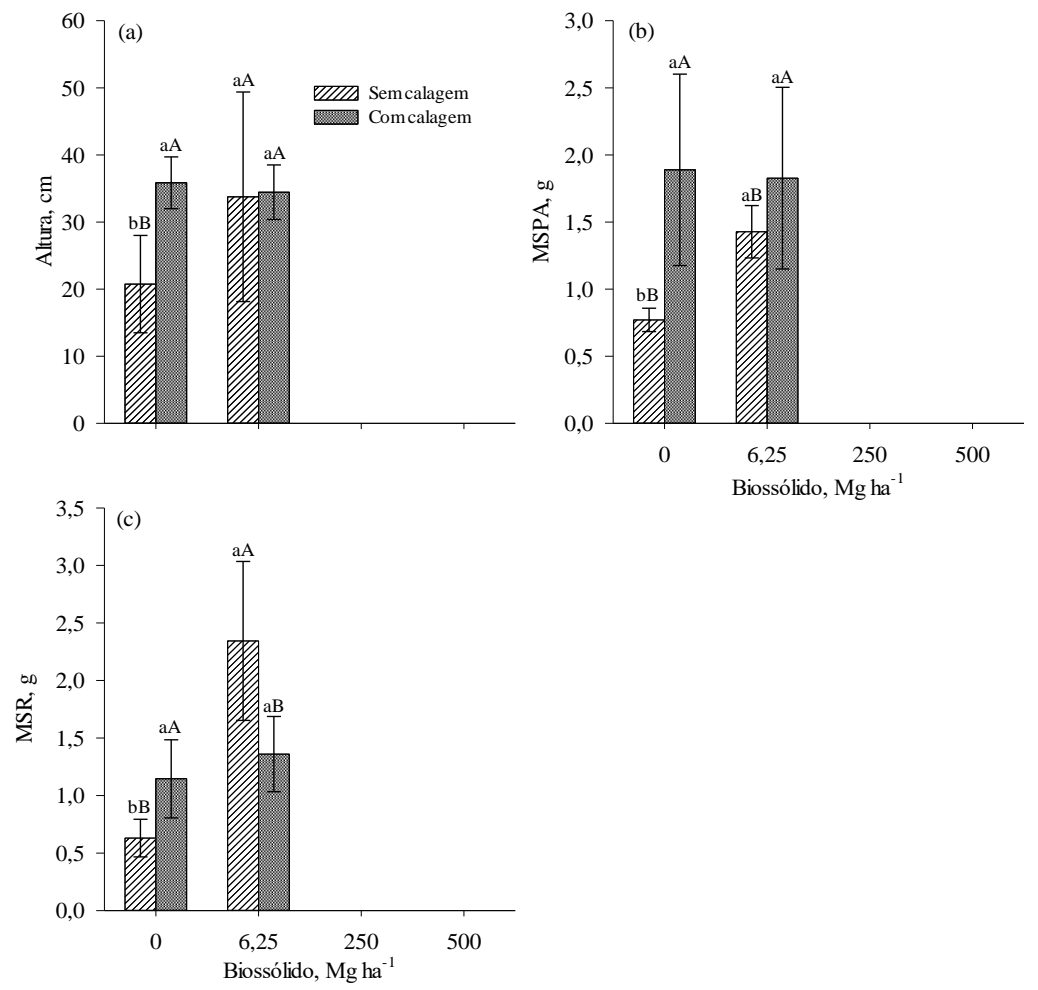

\subsection{Estudo 2 - Efeito do biossólido no teor de nitrogênio e fósforo da parte área das plantas consorciadas em experimento em casa de vegetação}

Os resultados da determinação do teor de $\mathrm{N}$ e $\mathrm{P}$ indicaram que o consórcio de plantas testado no experimento é influenciado pela 
concentração de biossólido, quando incorporado ao substrato de crescimento dessas espécies, enquanto que a realização da calagem não afetou os parâmetros analisados (Figura 15a, 15b).

Os resultados relacionados ao teor de $\mathrm{N}$ na parte aérea das plantas demonstram que o uso de biossólido no substrato aumentou as concentrações relativas de $\mathrm{N}$ na parte aérea das plantas (Figura 15a). Quando o biossólido foi utilizado sem calagem os incrementos foram de $32 \%$, e quando da realização da calagem, o uso do biossólido proporcionou incrementos de $66 \%$ nos teores de $\mathrm{N}$ da parte aérea quando comparado ao tratamento controle.

Figura 15. Teores de $\mathrm{N}$ (a) e $\mathrm{P}$ (b) em consórcio de aveia preta, ervilhaca e azevém em substrato com diferentes concentrações de biossólido em solo com e sem calagem. Barras verticais representam o desvio padrão da média $(\mathrm{n}=10)$. Médias seguidas da mesma letra, minúscula entre as doses de biossólido e maiúscula comparando o efeito da calagem na mesma dose de biossólido, não diferem entre si pelo teste de Scott-Knott (1974) a 5\% de probabilidade de erro.
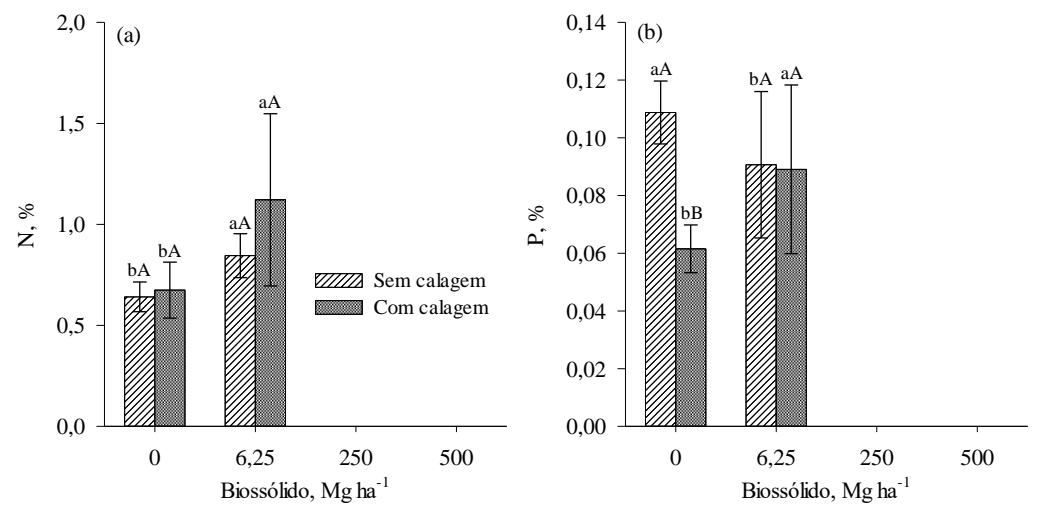

Para o teor de $\mathrm{P}$ determinado na parte aérea das plantas, os tratamentos apresentaram diferenças significativas com a presença do biossólido. Todavia, não houve diferença quando comparados os tratamentos com e sem calagem na dosagem de $6,25 \mathrm{Mg} \mathrm{ha}^{-1}$ de biossólido incorporado ao substrato. A adição de $6,25 \mathrm{Mg} \mathrm{ha}^{-1}$ de biossólido no substrato sem calagem proporcionou um decréscimo de $22 \%$ (de 0,109 para $0,089 \mathrm{~g} \mathrm{~kg}^{-1}$ ) no teor de $\mathrm{P}$ presente na parte área das plantas, em comparação ao controle do mesmo tratamento (Figura 15b). Entretanto, observou-se um comportamento diferente no tratamento em que o substrato foi submetido à calagem. Ao comparar o controle com o 
tratamento que recebeu $6,25 \mathrm{Mg} \mathrm{ha}^{-1}$ de biossólido, constatou-se um acréscimo de $44 \%$ no teor de $\mathrm{P}$ (de 0,062 para $0,089 \mathrm{~g} \mathrm{~kg}^{-1}$ ).

\subsection{Estudo 2 - Efeito do biossólido na colonização micorrízica radicular e esporulação das plantas consorciadas em experimento em casa de vegetação}

Para a esporulação, os tratamentos apresentaram diferenças significativas tanto para a presença do biossólido nos tratamentos, quanto para a calagem. Em todos os tratamentos a adição do calcário provocou redução no número de esporos do solo. Os maiores valores de esporulação foram encontrados nos tratamentos controle e $6,25 \mathrm{Mg} \mathrm{ha}^{-1}$ de biossólido que não receberam a calagem, estes por sua vez não variaram estatisticamente. Ao comparar os tratamentos controle, com e sem calagem, verifica-se que a adição de calcário ao solo proporcionou redução de $60 \%$ no número de esporos do solo (Figura 16a).

Entre os tratamentos com calagem, observa-se maior esporulação no tratamento controle, sendo que os tratamentos com 6,25; 250 e $500 \mathrm{Mg} \mathrm{ha}^{-1}$ não apresentaram diferença entre si. Analisando o número de esporos pré-experimento e pós-experimento (Figura 16a), observa-se um aumento, ainda que pequeno, no número de esporos até o tratamento com 6,25 $\mathrm{Mg}$ ha $^{-1}$ de biossólido sem calagem, sugerindo que o biossólido até essa concentração possui um efeito positivo para esse parâmetro. Por outro lado, ao comparar o número médio de esporos préexperimento e o tratamento controle com calagem, é evidente a influência negativa da calagem, provocando uma redução de $77 \%$ na esporulação.

Com relação à colonização micorrízica, os tratamentos não apresentaram diferenças significativas para esse parâmetro com a presença do biossólido em diferentes concentrações. Da mesma forma, os tratamentos com e sem calagem também não diferiram, demostrando que a calagem e o biossólido não influenciaram esse parâmetro (Figura $16 b)$.

Com relação à colonização micorrízica, os tratamentos não apresentaram diferenças significativas para esse parâmetro com a presença do biossólido em diferentes concentrações. Da mesma forma, os tratamentos com e sem calagem também não diferiram, demostrando que a calagem e o biossólido não influenciaram esse parâmetro (Figura $16 b)$. 
Figura 16. Número de esporos (a) e colonização micorrízica (b) nas raízes de aveia preta, ervilhaca e azevém consorciadas em solo de áreas degradadas pela mineração de carvão, após adição de diferentes doses de biossólido, em experimento conduzido em casa de vegetação. Barras verticais representam o desvio padrão da média $(\mathrm{n}=10)$. Linha tracejada representa a média do número de esporos antes da aplicação do biossólido $(\mathrm{n}=10)$. Médias seguidas da mesma letra, minúscula entre as doses de biossólido e maiúscula comparando o efeito da calagem na mesma dose de biossólido, não diferem entre si pelo teste de Scott-Knott (1974) a 5\% de probabilidade de erro.
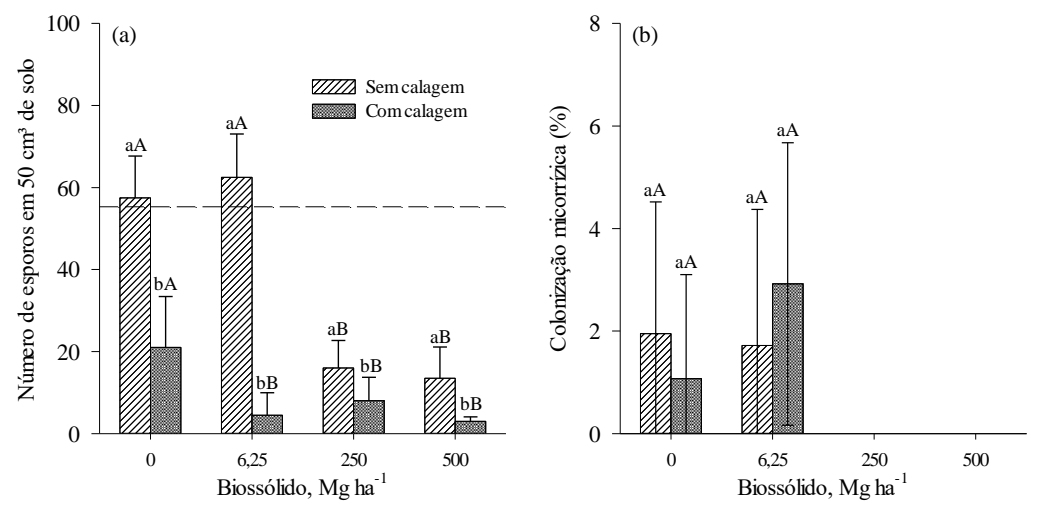

\subsection{Estudo 2 - Efeito do biossólido na nodulação radicular}

A avaliação do sistema radicular do consórcio de plantas estudado revelou a ausência de nódulos de rizóbio em todos os tratamentos com e sem adição da calagem e do biossólido. 


\section{DISCUSSÃO}

No presente estudo, com experimentos conduzidos a campo e em casa de vegetação, foram avaliadas as respostas no crescimento vegetal do consórcio de aveia preta, ervilhaca e azevém, nas propriedades químicas e biológicas do solo, na simbiose radicular das micorrizas arbusculares e das bactérias fixadoras de $\mathrm{N}$, na esporulação de FMA e na respiração basal do solo, através da incorporação de diferentes concentrações de biossólido em solo impactado pela mineração de carvão, e o efeito da calagem em alguns desses parâmetros.

Em solos alterados pela mineração de carvão, aspectos como a reduzida disponibilidade de matéria orgânica, os baixos valores de $\mathrm{pH}$ e a disponibilidade de elementos traço podem comprometer o sucesso do estabelecimento de espécies vegetais. A área de estudo é formada, principalmente, por pilhas de estéril da mineração do carvão ou depósitos de rejeitos do beneficiamento do carvão, passivos ambientais oriundos da atividade de mineração de carvão a céu aberto. Em termos gerais, nas áreas abandonadas pela mineração de carvão a céu aberto, a superfície do solo foi completamente suprimida da vegetação e as camadas de solo e rochas que recobrem os bancos de carvão são removidas, causando alterações no perfil do solo original (DIAS, 1998; CAMPOS et al., 2014).

Foram avaliados os atributos químicos do solo após implantação dos experimentos a campo e em casa de vegetação, utilizando diferentes concentrações de biossólido incorporadas ao solo. Em relação ao pH do solo, não houve variação desse parâmetro no experimento a campo em nenhum dos tratamentos avaliados, diferentemente do que foi observado em casa de vegetação. As concentrações elevadas de biossólido proporcionaram maiores valores de $\mathrm{pH}$ e, mesmo sem a calagem, ocorreu a correção do $\mathrm{pH}$ do solo nos tratamentos com 250 e $500 \mathrm{Mg} \mathrm{ha}^{-1}$ de biossólido, atingindo valores acima dos preconizados pela CQFS-RS/SC (2016).

Mesmo assim, o incremento nos valores do $\mathrm{pH}$ não foi suficiente para manter o crescimento das plantas em casa de vegetação, evidenciando que outros atributos físico-químicos interferiram nesse parâmetro. $\mathrm{O} \mathrm{pH}$ do solo influencia a disponibilidade do $\mathrm{Al}$, sendo que em solos com pH abaixo de 5,5 ocorre dissolução das formas precipitadas do $\mathrm{Al}$ promovendo a liberação de formas iônicas $\left(\mathrm{Al}^{3+}\right)$ na solução do solo, dessa forma o Al passa a ocupar os sítios de troca 
catiônica e, se absorvido pelas plantas, inibe o crescimento e desenvolvimento das mesmas (ALCARDE, 1992). Devido ao poder de correção da acidez do solo proporcionado pelo biossólido utilizado, verificou-se que os teores de $\mathrm{Al}$ do solo decresceram nos tratamentos à medida que se aumentaram as doses do material.

Para o experimento a campo, os valores mais altos de $\mathrm{pH}$ foram observados na camada $0-5 \mathrm{~cm}$, entretanto os valores são considerados baixos (CQFS-RS/SC, 2016), provavelmente, devido à presença dos estéreis de mineração e a oxidação da pirita (KOPPE; COSTA, 2008). O $\mathrm{pH}$ do solo é o atributo que interfere de forma mais intensa na disponibilidade de nutrientes no solo, sendo o $\mathrm{pH}$ ideal para o desenvolvimento das plantas na faixa de 5,5 a 6,5 (CQFS-RS/SC, 2016). $\mathrm{O} \mathrm{pH}$ alcalino, por sua vez, aumenta a disponibilidade de alguns macronutrientes e diminui a de alguns micronutrientes (MALAVOLTA et al., 1997).

O aumento das doses de biossólido promoveu redução na acidez potencial do solo nos dois experimentos. A acidez potencial é a capacidade do solo em resistir a alteração do $\mathrm{pH}$. A aplicação de biossólido ao solo proporciona um grande aporte de carga orgânica, aumentando a matéria orgânica do solo.

$\mathrm{O}$ incremento da matéria orgânica do solo proporcionada pelo biossólido é uma característica de grande relevância, principalmente para áreas degradadas. O biossólido apresenta em sua composição nutrientes e elementos benéficos imprescindíveis ao desenvolvimento e produção vegetal. Por estarem na maior parte na sua forma orgânica, a mineralização ocorre de forma gradual ao solo através de processos oxidativos, através da mineralização da matéria orgânica, o que por sua vez, faz a absorção desses nutrientes pelas plantas mais eficaz e diminui o risco de poluição ambiental (ANDREOLI, 2001). Castro et al. (2002) relataram incremento significativo nos teores de COT no solo em função do uso de lodo de esgoto como adubo orgânico em áreas degradadas. Por outro lado, os teores de COT encontrados no experimento a campo não apresentaram variação entre os tratamentos não havendo, portanto, efeito das concentrações de biossólido sobre esse parâmetro, necessitando de um período mais longo para que sejam observadas maiores mudanças (LEITE, et al., 2003; BELO et al., 2012). No experimento em casa de vegetação, os valores de COT responderam de forma significativa à presença do biossólido, sendo os maiores valores foram obtidos nos tratamentos com 250 e $500 \mathrm{Mg}^{-1}$ de biossólido com calagem. $\mathrm{O}$ aumento da concentração de COT no solo pela adição 
de resíduos orgânicos em solos degradados proporciona a manutenção do $\mathrm{C}$ orgânico no solo, sendo prática fundamental para a estabilidade da estrutura do solo e aumento da sua fertilidade (CARNEIRO et al., 2008).

O uso do biossólido também aumentou a disponibilidade de nutrientes no solo com o aumento dos teores de $\mathrm{P}$ e K. Isso ocorreu devido aos elevados teores desses nutrientes contidos no biossólido, o que favorece o desenvolvimento das plantas. Nesse sentido, avaliando o crescimento de espécies arbóreas em solo degradado, Modesto et al. (2009) também observaram incremento nos teores de $\mathrm{P}$ e $\mathrm{K}$ proporcionados pela adição de lodo de esgoto (30\%) em solo degradado. Corrêa et al., (2010) relataram aumento nos teores de P e K em substrato contendo doses crescentes de biossólido para o cultivo de plantas em solos degradados. Andreoli (1999) realizando experimentos a campo com aveia e milho em diferentes dosagens de lodo (6, 12 e $18 \mathrm{t} / \mathrm{ha})$ verificou que, embora a produtividade de milho e aveia não apresentaram diferenças estatísticas, observou um aumento significativo nos teores de $\mathrm{P}$ e $\mathrm{K}$ proporcionais às dosagens utilizadas de lodo.

$\mathrm{O} \mathrm{P}$ é um dos nutrientes mais limitantes para o crescimento e desenvolvimento inicial das plantas (FURTINI NETO et al., 2001). No tratamento com $6,25 \mathrm{Mg} \mathrm{ha}^{-1}$ de biossólido houve um incremento nos teores de $\mathrm{P}$ com a presença da calagem. No entanto, não foram verificados efeitos significativos $(p<0,05)$ da calagem nos demais tratamentos. Isso pode ser explicado devido a um pequeno aumento do $\mathrm{pH}$, proporcionando uma diminuição na complexação do $\mathrm{P}$ no solo, tornando-o mais disponível.

De acordo com Prochnow et al. (2004), a disponibilidade de íons fosfato no solo está diretamente relacionada ao $\mathrm{pH}$, pois com a elevação do pH ocorre aumento das cargas negativas e redução das positivas no complexo de troca, diminuindo a solubilidade de compostos de $\mathrm{Al}$ e Fe. Essa reação proporciona um aumento na concentração de $\mathrm{P}$ na solução do solo, tornando o ambiente mais favorável ao desenvolvimento da vegetação, podendo traçar assim uma relação direta com os teores de $\mathrm{P}$ foliares encontrados nos resultados dos experimentos.

No experimento a campo, os maiores teores de $\mathrm{P}$ foliar foram encontrados nos tratamentos que receberam as doses de 100 e $250 \mathrm{Mg}$ ha $^{-1}$ de biossólido. Guedes e Poggiani (2003), no entanto, relataram aumento nos teores de $\mathrm{P}$ e $\mathrm{N}$ foliar em Eucalyptus grandi, nos tratamentos com maiores concentrações de biossólido, correspondente a 
$40 \mathrm{t} \mathrm{ha}^{-1}$. Em estudos com cultivo de plantas de sorgo granífero, Liveira et al. (1993) constataram que doses crescentes de lodo de esgoto promoveram maior absorção de $\mathrm{P}, \mathrm{N}, \mathrm{Mg}$, e $\mathrm{Ca}$ nas plantas. $\mathrm{O}$ tratamento $500 \mathrm{Mg} \mathrm{ha}^{-1}$ de biossólido, no entanto, mostrou uma redução no teor de $\mathrm{P}$ foliar. Para o experimento em casa de vegetação, a quantidade máxima absorvida de $\mathrm{P}$ foi identificada já no tratamento controle.

Com relação aos teores de $\mathrm{N}$ no tecido foliar, verificou-se em ambos os experimentos incrementos nos teores de $\mathrm{N}$ relacionados à presença do biossólido. $\mathrm{O} \mathrm{N}$ está diretamente relacionado com o desenvolvimento vegetal e sua deficiência pode causar prejuízos ao crescimento das plantas (MALAVOLTA, 2006). A recomendação da quantidade de biossólido a ser aplicada é normalmente feita tomando-se como base os teores de $\mathrm{N}$ no biossólido, levando-se em consideração a taxa de mineralização (MELO et al., 2001), e os requerimentos da cultura para esse nutriente. $\mathrm{O}$ resultado da análise do biossólido mostrou que o $\mathrm{N}$ encontra-se na concentração de $14,2 \mathrm{~g} \mathrm{~kg}^{-1}$. O N presente no biossólido foi suficiente suprir a necessidade requerida para $\mathrm{o}$ desenvolvimento adequado das plantas consorciadas utilizadas no experimento que, segundo a literatura, é de $20 \mathrm{~kg} \mathrm{ha}^{-1}$ (CQFS-RS/SC, 2016).

De acordo com Campos et al. (2010), a recuperação de solos degradados pode ser buscada por meio da cobertura vegetal que tenham facilidade de estabelecimento, rápido desenvolvimento de cobertura e que melhorem as condições físicas, químicas e biológicas do solo. A vegetação que se estabelece espontaneamente nas áreas de mineração de carvão é constituída, basicamente, por plantas pioneiras e ruderais, pouco exigentes em fertilidade do solo, resistentes a estiagens prolongadas e com grande capacidade de competição e adaptação (CITADINI-ZANETTE; BOFF, 1992).

A consorciação de espécies gramíneas e leguminosas de ciclos curtos representa, atualmente, uma potencial alternativa aos programas de recuperação de áreas degradadas pela mineração de carvão. Essas espécies destacando-se em virtude de seu rápido crescimento, elevada produção de fitomassa e capacidade de associação simbiótica com bactérias fixadoras de $\mathrm{N}$ e FMA (CALEGARI, 1992), além de apresentarem uma adaptação favorável ao ambiente com baixa disponibilidade de nutrientes e $\mathrm{pH}$ ácido. Essas espécies podem se beneficiar da adição do biossólido para seu estabelecimento no campo, conforme dados obtidos neste trabalho. 
A altura da parte aérea das plantas e a produção de matéria seca aérea e radicular são parâmetros fundamentais para se avaliar a sobrevivência da vegetação no campo (SABONARO, 2006; FAVALESSA, 2011). Além disso, vários autores mostram que há uma relação direta entre a produção de matéria seca da parte área e a produção de matéria seca do sistema radicular. De acordo com Rosa et al. (2007), esses parâmetros estão intimamente relacionados, já que o bom desenvolvimento da parte área de uma planta depende do bom desenvolvimento de seu sistema radicular. Fetene \& Feleke (2001) citam em seus estudos, que em função do aumento da área de absorção dos nutrientes disponíveis no solo pelas raízes, há um crescimento mais rápido da porção aérea da planta, produzindo maior fitomassa.

De acordo dados obtidos nos experimentos, doses crescentes de biossólido proporcionam melhor crescimento em altura e produção de MSPA e MSR das plantas. O aumento da altura, da MSPA e MSR pode estar relacionado ao fornecimento de P e N, através do biossólido, para as plantas (MARSCHNER, 2012). Caldeira et al. (2013) e Rocha et al. (2013) encontraram maiores valores em altura e produção de MSPA e MSR em mudas de Eucalyptus quando cultivadas em substrato contendo $80 \%$ e $100 \%$ de lodo de esgoto, respectivamente, e associaram esses resultados ao incremento de $\mathrm{P}$ proporcionado pelo lodo de esgoto. Da mesma forma, Almeida et al. (2005) relataram o aumento da MSPA e MSR de espécies arbóreas com doses crescentes de lodo de esgoto aplicadas no plantio.

A fim de avaliar os efeitos do biossólido adicionado ao solo com as interações biológicas no sistema solo-planta, foram analisados os parâmetros colonização micorrízica radicular, esporulação e nodulação radicular nas espécies consorciadas submetidas a diferentes tratamentos com biossólido. A colonização micorrízica por FMAs e a esporulação não sofreram efeito com a adição de biossólido, não demostrando variação entre os tratamentos no experimento a campo. Por outro lado, o experimento conduzido em casa de vegetação mostrou variação no número de esporos entre os tratamentos e efeito significativo na redução do número de esporos com a calagem.

A contaminação do solo por elementos traço causa interferência nas diversas formas de vida e no funcionamento dos ecossistemas como um todo. A reduzida taxa de colonização micorrízica, observada nesse estudo, pode ser explicada pela presença de poluentes químicos no solo que afetam negativamente alguns processos do ciclo de vida dos FMAs, tais como a germinação de esporos, o crescimento de hifas e a 
colonização radicular (KLAUBERG-FILHO, et al, 2005). A retirada da vegetação e a substituição da camada superficial do solo original, bem como a exposição à temperatura e a solos ácidos também influenciam na redução do número de propágulos de fungos e na baixa colonização das plantas (MEHROTRA, 1998).

Outro fator que pode ter influenciado esses parâmetros é a composição do biossólido, especialmente a concentração de P. Segundo estudos realizados por Melloni et al. (2000) e Moreira \& Siqueira (2006), elevados teores de P no solo promovem reduções acentuadas na colonização micorrízica radicular. Em estudos desenvolvidos por Bettiol et al. (1986) com aplicação de doses de biossólido e sua influência na formação de FMAs em cultivo com Pinus, os autores destacaram a inibição na formação de micorrizas em todas as concentrações testadas $(10,30$ e $50 \%)$.

Os resultados encontrados no experimento em casa de vegetação mostraram que a calagem também pode influenciar na esporulação de FMA. Segundo Siqueira et al. (1986a), os FMAs apresentam comportamentos variados em relação ao aumento do $\mathrm{pH}$ do solo. A calagem, por exemplo, pode reduzir a formação de micorrizas, pois a elevação do $\mathrm{pH}$ tem efeitos adversos sobre o potencial de infecção dos fungos nativos adaptados às condições ácidas do solo, corroborando com os resultados encontrados no experimento em casa de vegetação. Por outro lado, em outro estudo Siqueira et al. (1990) citam efeitos benéficos da calagem, favorecendo a colonização por eliminar fatores que dificultam a infecção e atuarem sobre a germinação de esporos no solo, além de atuar sobre a composição das populações de FMAs.

De maneira geral, as plantas controlam a colonização micorrízica conforme a necessidade. A relação de causa e efeito no sistema solo-biossólido-planta não está clara, mas pode envolver uma menor dependência das plantas por FMAs para a aquisição de recursos. Com maior disponibilidade de $\mathrm{P}$ e melhor $\mathrm{pH}$ do solo, as plantas podem não necessitar tanto dessa simbiose (SMITH; READ, 2010), e o biossólido pode estar servindo de condicionador desses elementos para o sistema solo-planta.

Os FMAs dependem do simbionte para sua própria existência (GADKAR et al., 2001). O caráter facultativo pode ser observado em condições de solo com alta disponibilidade de nutrientes, em que plantas não necessitam de FMAs. Nessas condições, a simbiose é inibida por 
meio de mecanismos genéticos controlados pelas plantas (LAMBAIS et al., 2003).

Não foram observados nódulos nas raízes das plantas em nenhum dos experimentos. A ervilhaca é uma herbácea que se associa a bactérias fixadoras de $\mathrm{N}$, formando nódulos nas raízes (CALEGARI et al., 1993). Apesar dessa condição ser inerente a essa espécie, nenhum nódulo foi observado nas raízes das plantas durante os experimentos conduzido a campo e em casa de vegetação, indicando que as concentrações de biossólido testadas possam ter suprido as necessidades nutricionais das plantas por $\mathrm{N}$ e, possivelmente, possam ter influenciado a formação dos nódulos radiculares.

A respiração basal do solo $(\mathrm{RB})$ é utilizada como indicador de todas as atividades metabólicas realizadas pelos microrganismos do solo, principalmente bactérias e fungos, nas quais o $\mathrm{CO}_{2}$ é produzido através da degradação da matéria orgânica. Dessa forma, a RB está diretamente relacionada com a atividade microbiana do solo e com o carbono orgânico total (PARKIN et al., 1996; HENDRIX et al., 1988).

Os valores encontrados de COT nos tratamentos analisados a campo podem estar relacionados ao manejo incorreto do solo com falta de entrada de carbono orgânico no sistema, devido à incorporação incorreta do biossólido no solo. A má incorporação da matéria orgânica pode refletir, num primeiro momento, no aumento do consumo da matéria orgânica disponível pela microbiota do solo, porém, num segundo momento, no decréscimo da respiração microbiana do solo devido à redução do C prontamente oxidável (VIEIRA et al., 2011).

Para a RB não houve diferenciação entre os tratamentos quanto a liberação de $\mathrm{C}-\mathrm{CO}_{2}$, com uma média geral de $0,28 \mathrm{mg} \mathrm{C}-\mathrm{CO}_{2} \mathrm{~g}^{-1}$ solo $\mathrm{h}^{-1}$. O valor médio da $\mathrm{RB}$ obtido antes da implantação do experimento foi de $0,30 \mathrm{mg} \mathrm{C}-\mathrm{CO}_{2} \mathrm{~g}^{-1}$ solo $\mathrm{h}^{-1}$, não diferindo dos tratamentos. Provavelmente todo o $\mathrm{C}$ presente no solo já havia sido consumido antes da coleta das amostras. Holanda Neto (2010) também não encontraram diferenças significativas na $\mathrm{RB}$ de solos construídos de áreas de mineração de carvão submetidos a diferentes cultivos de gramíneas. Por outro lado, Santos et al. (2008) ao avaliarem as modificações na biomassa e na atividade microbiana de um solo em função do cultivo de diferentes espécies de cobertura vegetal, relataram intensa liberação de $\mathrm{CO}_{2}$ em todos os tratamentos analisados.

A RB é um indicador bastante sensível em resposta às alterações no meio, tais como, disponibilidade de substrato, umidade, temperatura, tipo de manejo empregado no solo, adição de adubo, 
resíduos de plantas e insumos (BENIZRI e AMIAUD, 2005; BAARU et al., 2007). Por isso, ao mesmo tempo em que a RB reflete a atividade respiratória de um ambiente com alta produtividade pode refletir o estresse provocado no meio por um passivo ambiental (SILVA et al., 2007). 


\section{CONCLUSÕES}

- O uso de biossólido em áreas degradadas pela mineração de carvão proporcionou melhorias na fertilidade do solo, especialmente, com elevação do $\mathrm{pH}$ do solo, incremento nos teores de nutrientes, como o P e $\mathrm{K}$, e aumento dos teores de COT, o que melhora as condições para o estabelecimento de vegetação.

- Concentrações iguais a $100 \mathrm{Mg} \mathrm{ha}^{-1}$ de biossólido na composição do substrato proporcionam maior incremento em altura, MSPA e MSR de aveia preta, ervilhaca e azevém consorciadas, cultivadas em solos degradados pela mineração de carvão.

- Concentrações iguais ou superiores a $250 \mathrm{Mg} \mathrm{ha}^{-1}$ de biossólido na composição do substrato foram prejudiciais ao crescimento de aveia preta, ervilhaca e azevém consorciadas em casa de vegetação.

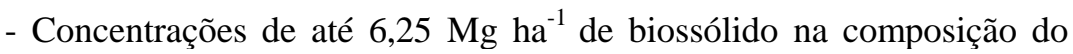
substrato proporcionaram efeitos positivos na esporulação de FMA, em tratamento sem calagem. A calagem interferiu negativamente na esporulação de FMA em experimento em casa de vegetação.

- A adição de diferentes concentrações de biossólido não influenciaram os parâmetros colonização micorrízica, respiração basal do solo e nodulação radicular nos dois Estudos avaliados.

- O uso do biossólido como componente de substrato em áreas degradadas pela mineração de carvão é uma alternativa viável para a disposição final desse resíduo tendo em vista a economia de fertilizante que esse material pode proporcionar, além dos benefícios ambientais, associados a seu uso. 


\section{CONSIDERAÇÕES FINAIS}

Estudos a curto e a longo prazo tem concluído como vantajosa a utilização do biossólido em relação à recuperação das propriedades do solo e da produtividade das culturas. Nesse sentido, a recuperação de áreas degradadas com a aplicação do biossólido no solo proporciona rápido estabelecimento e crescimento de herbáceas, contribuindo com a proteção ao solo e aporte de biomassa vegetal para manutenção dos ciclos produtivos. Todavia, seu uso deve ser feito com restrições devido à presença de elementos indesejáveis ao meio ambiente, e em elevadas concentrações no biossólido, a fim de garantir a sanidade ambiental e a sua utilização segura. 


\section{REFERÊNCIAS}

ALBUQUERQUE, J. A. et al. Atividades agrícolas de produção em solos frágeis no sul do Brasil. Tópicos em Ciência do Solo, Viçosa, v. 7, p. 367- 403, 2011.

ALEXANDRE, N. Z. Diagnóstico ambiental da Região carbonífera de Santa Catarina: degradação dos recursos naturais. Revista Tecnologia e Ambiente, v.5, n.2, p.35 -50, 1999.

ALVES, M. C. et al. Qualidade física de um solo degradado em recuperação há 6 anos. Holos Enviroment, v.11, n.2, 2011.

AMARAL, J. E.; KREBS, A. S. J. Drenagem ácida da mineração de carvão e sua inter-relação com metais pesados e recarga de aquíferos na bacia carbonífera do Estado de Santa Catarina. In: Congresso Brasileiro de Águas Subterrâneas, 16. São Luís - MA. Anais do Congresso Brasileiro de Águas Subterrâneas. São Paulo: ABAS, 2010.

ANDERSON, T. H.; DOMSCH, K. H. Siol microbial biomass: The ecophysiological approach. Soil Biology and Biochemistry. 1-5 p. 2010.

ANDRADE, R.S.; STONE, L.F.; SILVEIRA, P.M. Culturas de cobertura e qualidade física de um Latossolo em plantio direto. Revista Brasileira de Engenharia Agrícola e Ambiental, v.13, n.4, p.411-418. 2009.

ANDREOLI, C. V. et al. Gestão dos Biossólidos Gerados em Estações de Tratamento de Esgoto Doméstico. Curitiba: Engenharia e Construção, n. 24, setembro/98.

ANDREOLI, C.V. Uso e manejo do lodo de esgoto na agricultura. Rio de Janeiro: Abes, 1999. 97 p.

ANDREOLI, C. V. Resíduos sólidos do saneamento: processamento, reciclagem e disposição final, Projeto PROSAB, RiMa, ABES: Rio de Janeiro, 2001. 
ANDREOLI, C.V. et al. Uso de lodo de esgoto na produção de substrato vegetal. In: Alternativas de uso de resíduos de saneamento. Rio de Janeiro: Abes, 2006.

AUMOND, J. J. Teoria dos Sistemas: uma nov abordagem para recuperação e restauração ambiental. In: SIMPOSIO BRASILEIRO DE ENGENHARIA AMBIETAL, 2. 2003, Itajaí. Anais... Itajaí, p. 10-16. UNIVALI, 2003.

BAARU, M.W. et al. Soil microbial biomass carbon and nitrogen as influenced by organic and inorganic inputs at Kabete, Kenya. A. Bationo (eds.), Advances in Integrated Soil Fertility Management in Sub-Saharan Africa: Challenges and Opportunities, 827-832 p. 2007.

BACKES, C.; BULL, L. T.; GODOY, L. J. G.; VILLAS BÔAS, R. L.; LIMA, C. P.; PIRES, E. C. Uso de lodo de esgoto na produção de tapetes de grama esmeralda. Ciência Rural, Santa Maria, v. 39, n. 4, p. 1045-1050, 2008.

BARÉS, E. M. Digestão e higienização de lodo de estação de tratamento de esgotos através de processo bifásico com pré-tratamento térmico. Dissertação de Mestrado. Curitiba, 134p. 2010.

BELO, E.S. et al. Decomposição de diferentes resíduos orgânicos e efeito na atividade microbiana em um Latossolo Vermelho de Cerrado. Global Sci. Technol., 5:107-116, 2012.

BELOLli, M.; QUADROS, J.; GUIDI, A. A história do carvão de Santa Catarina. Criciúma: Imprensa Oficial do Estado de Santa Catarina, 2002. 300 p. Disponível em: <http://www.siesesc.com.br>. Acesso em 20 julho 2016.

BENINTENDE, S. M. et al. Soil microbiological indicators of soil quality in four rice rotations systems. Ecological indicator, vol 8, 704708 p. 2008.

BENIZRI, E.; AMIAUD, B. Relationship between plants and soil microbial communities in fertilized grasslands. Soil Biology and Biochemistry, v.37, p.2055-2064, 2005 
BERTONI, J; LOMBARDI NETO, F. Conservação do Solo, $7^{\text {a }}$ Edição, Editora Ícone. São Paulo, SP. 355p. 2008.

BETTIOL, WAGNER et al. Influência de lodo de esgoto e de acículas de pinus na formação da ectomicorrizas em mudas de Pinus caribaea var. hondurensis pelos fungos Pisolithus tinctorius e Thelephora terrestris. IPEF, v. 34, p. 41-6, 1986.

BETTIOL, W; CAMARGO O. A. A disposição de lodo de esgoto em solo agrícola. In: Lodo de esgoto: impactos ambientais na agricultura. Embrapa Meio Ambiente, Jaguariúna, Embrapa Meio Ambiente, 2006.

BETTIOL, W.; CAMARGO, O.A. Impacto ambiental do uso agrícola do lodo de esgoto. Jaguariúna: Embrapa Meio Ambiente, 2000. 312p.

BETTIOL, W; FERNANDES, S. Efeito do lodo de esgoto na comunidade microbiana e atributos químicos do solo. Jaguariúna: Embrapa Meio Ambiente, 2004.

BI, Y.-L.; WU, F.-Y.; WU, Y.-K. Application of arbuscular mycorrhizal in restoration of areas affected by coal mining in China. Acta Ecologica Silica, v. 2073, 2005.

BONNET, B. R. P.; LARA, A. I.; DOMASZAK, S. C. Indicadores biológicos de qualidade sanitária do lodo de esgoto. ANDREOLI, CV; BONNET, BRP (Coord.) Manual de métodos para análises microbiológicas e parasitológicas em reciclagem agrícola de lodo de esgoto, p. 11-26, 1998.

BRASIL. Ministério do Meio Ambiente. Resolução CONAMA n. 001 de 23 de janeiro de 1986. Confere o artigo 48 do Decreto $\mathrm{n}^{\circ} 88.351$, de $1^{\circ}$ de junho de 1983, para efetivo exercício das responsabilidades que lhe são atribuídas pelo artigo 18 do mesmo decreto, e Considerando a necessidade de se estabelecerem as definições, as responsabilidades, os critérios básicos e as diretrizes gerais para uso e implementação da Avaliação de Impacto Ambiental como um dos instrumentos da Política Nacional do Meio Ambiente. Coleção de leis [do] Ministério do Meio Ambiente.

Disponível

em: 
<http://www.mma.gov.br/port/conama/res/res86/res0186.html> Acesso em: 20 julho 2016.

BRASIL. MINISTÉRIO DO MEIO AMBIENTE, CONSELHO NACIONAL DO MEIO AMBIENTE. Resolução no 375 de 29 de agosto de 2006. Define critérios e procedimentos, para o uso agrícola de lodos de esgoto gerados em estações de tratamento de esgoto sanitário e seus produtos derivados, e dá outras providências. Brasília.

BROFAS, G.; MICHOPOULOS, P.; ALIFRAGIS, D. Sewage sludge as an amendment for calcareous bauxite mine spoils reclamation. Journal of environmental quality, v. 29, n. 3, p. 811-816, 2000.

BUNDGAARD, E.; SAABYE, A. State of the art on sewage sludge: environmental aspects and regulations of common sludge disposal methods. In: INTERNATIONAL EXHIBITION CONGRESS OF SOLID WASTE. Anais. Madrid: ISWA, 1992.

CABRAL, L., S., J. O.; SOARES, C. R. F. S.; PINTO, J. E. B. P. Retenção de metais pesados em micélio de fungos micorrízicos arbusculares. Quim. Nova, 33(1), 25-29. 2010.

CAMPOS, M. L.; ALMEIDA, J. A.; SOUZA, L. S. Avaliação de três áreas de solo construído após mineração de carvão a céu aberto em Lauro Müller, Santa Catarina. Revista Brasileira de Ciência do Solo, v.27, n.6, p.1123-1137, 2003.

CARNEIRO, M.A.C. et al. Atributos bioquímicos em dois solos de Cerrado sob diferentes sistemas de manejo e uso. Pesq. Agropec. Trop., 38:276-283, 2008.

COMPANHIA DE SANEAMENTO DO PARANÁ. Manual técnico para utilização agrícola do lodo de esgoto no Paraná. Curitiba: SANEPAR, 1997.

CALDEIRA, M. V. W. et al. Crescimento de mudas de Eucalyptus grandis utilizando lodo de esgoto, fibra de coco e palha de café in natura. Floresta, v. 44, n. 2, p. 195-206, 2013. 
CAMPOS, M. L. et al. Impactos no solo provocados pela mineração e depósito de rejeitos de carvão mineral. Revista de Ciências Agroveterinárias, v. 9, n. 2, p. 198-205, 2010.

CAMPOS, M. L. et al. Impactos no solo provocados pela mineração e depósito de rejeitos de carvão mineral. Revista de Ciências Agroveterinárias, v. 9, n. 2, p. 198-205, 2014.

CASTILHOS, Z. C.; FERNANDES, F. R. C. A bacia carbonífera sul catarinense e os impactos e passivos da atividade da indústria extrativa mineral de carvão na territorialidade. In: FERNANDES, F. R. C.; ENRÍQUEZ, M. A. R. S.; ALAMINO, R. C. J. (Ed.). Recursos minerais e sustentabilidade territorial: grandes minas. Rio de Janeiro: CETEM/MCTI, 2011. p. 361-386.

CASTRO, L. A. R. et al. Efeitos do lodo de esgoto como recuperados de áreas degradadas com finalidade agrícola. V SIMPOSIO NACIONAL SOBRE RECUPERAÇÃO DE ÁREAS DEGRADADAS. Anais... jun., 2002.

CETESB. Aplicação de biossólidos em áreas agrícolas - critérios para projeto e operação. Norma Técnica P4230. São Paulo, SP. 32p. 1999.

CITADINI-ZANETTE, V.; BOFF, V. P. Levantamento florístico em áreas mineradas a céu aberto na região carbonífera de Santa Catarina, Brasil. Florianópolis: Secretaria de Estado da Tecnologia. Energia e Meio Ambiente, 1992.

CLAPP, C. E et al. Sewage suldge organic matter and soil properties. In: CHEN, Y.; AVNIMELECH, Y. The role of organic matter in modern agriculture. Amsterdam: M. Nijhoff, 1986.

COMISSÃO DE QUÍMICA E FERTILIDADE DO SOLO - RS/SC. Manual de calagem e adubação para os estados do Rio Grande do Sul e de Santa Catarina. 11 ed. Núcleo Regional Sul, 2016. 376 p.

CORRÊA, R.S.; BENTO, M.A.B. Qualidade do substrato minerado de uma área de empréstimo revegetada no Distrito Federal. Revista Brasileira de Ciência do Solo, v.34, p.1435-1443, 2010. 
COSTA, S.; ZOCCHE, J. J.; SOUZA, P. Z. Absorção de elementostraço $(\mathrm{Zn}$ e $\mathrm{Pb})$ por Axonopus obtusifolius (Raddi) em áreas degradadas pela mineração de carvão, SC, Brasil. Revista Brasileira de Biociências, Porto Alegre, v. 5, n. 1, p. 795-797. 2007.

COSTA, A.N. et al. Lodo de esgoto: utilização sustentável. Vitória, 2008.

COSTA, A. N.; COSTA, A. F. S. Manual de uso agrícola e disposição do lodo de esgoto para o Estado do Espírito Santo. Vitória: Incaper, 2011.

COSTA, S.; ZOCCHE, J. J. Fertilidade de solos construídos em áreas de mineração de carvão na região Sul de Santa Catarina. Revista Árvore, Viçosa, v. 33, n. 4, p. 665-674, 2009.

DA SILVA, Mozaniel Batista et al. Atributos biológicos do solo sob influência da cobertura vegetal e do sistema de manejo. Pesquisa Agropecuária Brasileira, v. 42, n. 12, p. 1755-1761, 2007.

DE ARAÚJO, A. S. F.; MONTEIRO, R. T. R. Indicadores biológicos de qualidade do solo. Bioscience Journal, v. 23, n. 3, 2007.

DE SOUZA, C. A. et al. Lodo de esgoto em atributos biológicos do solo e na nodulação e produção de soja. Pesquisa Agropecuária Brasileira, v. 44, n. 10, p. 1319-1327, 2010.

DERPSCH, R.; CALEGARI, A. Plantas para adubação verde de inverno. Londrina: IAPAR, 80 p. 1992.

DIAS, L. E; MELLO, J. W. V. Recuperação de áreas degradadas. Viçosa: UFV, Departamento de Solos. SOBRADE. 251p. 1998.

DIAS, L. E.; PENEDO, A. P.; MELO, R. F. Revegetação de Substratos Sulfetados Remanescentes de Mineração. Departamento de solos, Universidade Federal de Viçosa. Viçosa-MG, 2005.

DO AMARAL, J. E.; KREBS, A. S. J. Drenagem ácida da mineração de carvão e sua interrelação com metais pesados e recarga de aquíferos na 
Bacia Carbonífera do Estado de Santa Catarina. Águas Subterrâneas, 2010.

EPAGRI. Dados e informações biofísicas da unidade de planejamento regional litoral sul catarinense-UPR 8. Boletim técnico. $77 \mathrm{p}$. Epagri/Ciram. Florianópolis, 2001.

EPSTEIN, E. Land application of sewage sludge and biosolids. 1.ed. London, New York, Washington: Lewis Publishers. 220p, 2003.

ERNANI, P.R. et al. Decréscimo da retenção de fósforo no solo pelo aumento do pH. Revista Brasileira de Ciências do Solo, 20:159-162, 1996.

FARIA, S. M. de. et al. Recuperação de solos degradados com leguminosas noduladas e micorrizadas. EMBRAPA-CNPAB. Documentos, 1998.

FARIAS, P. H. S.; SANTOS, H. I. Uso do lodo primário de esgoto urbano de ETE's na recuperação de áreas degradadas. Universidade Católica de Goiás. Goiânia. 14 p. 2007.

FERNANDES, S.A.P.; SILVA, S.M.C.P. Manual prático para a compostagem de biossólidos. Londrina: Prosab, Finep, 1999.

FERREIRA, D.F. Sisvar: a computer statistical analysis system. Ciência e Agrotecnologia (UFLA), v.35, n.6, p.1039-1042, 2011.

FETENE, M.; FELEKE, Y. Growth and photosynthesis of seedlings of four tree species from a dry tropical afromontane forest. Journal of tropical ecology, v. 17, n. 2, p. 269-283, 2001.

FLOSS, E. L. A cultura da aveia. Passo Fundo: Universidade de Passo Fundo, Faculdade de Agronomia e Medicina Veterinária, 52 p. 1982.

FONTANELI, R.S.; SANTOS, H.P. dos; FONTANELI, R.S. (Ed.). Forrageiras para integração lavoura pecuária floresta na região sul brasileira. Passo Fundo: Embrapa Trigo, 340p. 2009. 
FRANCO, A. A. et al. Revegetação de solos degradados. Seropédica, RJ: EMBRAPA -CNPAB, 11 p. 1992.

FRANCO, A. A.; CAMPELLO, E. F.; DIAS, L. E. Revegetação em áreas de mineração de bauxita em Porto Trombetas-PA com leguminosas arbóreas noduladas e micorrizadas. I Simpósio SulAmericano e II Simpósio Nacional - Recuperação de Áreas Degradadas. Foz do Iguaçu-PR. 1994. Anais... Foz do Iguaçu. p.145-153. 1994.

FRANCO, A. A.; RESENDE, A. S. de; CAMPELlO, E. F. C. Importância das leguminosas arbóreas na recuperação de áreas degradadas e na sustentabilidade de sistemas agroflorestais. Sistemas Agroflorestais e Desenvolvimento Sustentável, Mato Grosso do Sul, p. 1-24, 2003.

FRANCO, A. A. et al. Uso de leguminosas florestais noduladas e micorrizadas como agentes de recuperação e manutenção da vida do solo: um modelo tecnológico. In: ESSEVES, F.A. ed. Estrutura, Funcionamento e Manejo de Ecossistemas Brasileiros, Rio de Janeiro, Instituto de Biologia - UFRJ, p.459-467, 1995.

GASSEN, D., GASSEN, F. Pantio direto - o caminho do futuro. Ed. Aldeia Sul, Passo Fundo. 207p. 1996.

GERDEMANN, J.W.; NICHOLSON, T.H. Spores of mycorrhizal Endogone species extracted from soil by wet sieving and decanting. Transactions of the British Mycological Society, 46, 1963.

GIOVANNETTI, M; MOSSE, B. An evaluation of techniques for measuring vesicular arbuscular mycorrhizal infection in roots. New phytologist, 84(3), p.489-500, 1980.

GODOY, L. C. de. A logística na destinação do lodo de esgoto. Revista Científica On-line Tecnologia, Gestão e Humanismo. Faculdade de Tecnologia de Guaratinguetá, São Paulo: Revista v.2, n.1, nov. 2013.

GUEDES, M. C.; POGGIANI, F. Variação dos teores de nutrientes foliares em eucalipto fertilizado com biossólido. Scientia Florestalis, n.63, p.188-2001, 2003. 
HAYNES, R. J.; FRANCIS, G. S. Changes in microbial biomass C, soil carbohydrate composition and aggregate stability induced by growth of selected crop and forage species under field conditions. European Journal of Soil Science, v. 44, n. 4, p. 665-675, 1993.

HENDRIX, P.F.; HAN, C.R.; GROFFMAN, P.M. Soil respiration in conventional and no-tillage agroecosystems under different winter cover crop rotations. Soil Till. Res., 12:135-148, 1988.

INDA, A.V. et al. Atributos químicos relacionados ao processo de sulfurização em solos construídos após mineração de carvão. Ciência Rural, v.40, p.1060-1067, 2010.

ISERMEYER, H. Eine einfache Methode zur Bestimmung der Bodenatmung und der Karbonate im Boden. Z. Pfl anzenernäh Bodenk, v.56, p.26-38, 1952.

KLAUBERG-FILHO, O. et al. Ecologia, função e potencial de aplicação de fungos micorrízicos arbusculares em condições de excesso de metais pesados. VIDAL-TORRADO, P.; ALLEONI, LRF; COOPER, M, p. 85-144, 2005.

KOPPE, J.C.; COSTA, J.F.C.L. Mineração. In: TEIXEISRA, E. C. Meio Ambiente e Carvão: Impactos da exploração e utilização. Porto Alegre: FEPAM. cap.1. p.15-28. 2002.

KOPPE, J. C.; COSTA, J. F. C. L. A lavra de carvão e o meio ambiente em Santa Catarina. In: SOARES, P. S. M.; SANTOS, M. D. C.; POSSA, M. V. Carvão brasileiro: tecnologia e meio ambiente. Rio de Janeiro: CETEM/MCT, p. 25-38. 2008.

LARA, A. I.; ANDREOLI, C. V.; PEGORINI, E. S. - Avaliação dos impactos ambientais e monitoramento da disposição final do lodo - In: ANDREOLI, C. V.; SPERLING, M. von.; FERNANDES, F. Lodo de esgotos: tratamento e disposição final. Princípios do tratamento biológico de águas residuárias. Belo Horizonte: Departamento de Engenharia Sanitária e Ambiental - DESA/ UFMG e Companhia de Saneamento do Paraná - SANEPAR, v. 6, p. 462-482, 2001. 
LAMBAIS, M.R; CARDOSO, E.J.B.N. Germinação de esporos e crescimento do tubo germinativo de fungos vesículo-arbusculares em diferentes concentrações de alumínio. Revista Brasileira de Ciência do Solo, v.13, p.151-154, 1989.

LEITE, L.F.C. et al. Estoques totais de carbono orgânico e seus compartimentos em Argissolo sob floresta e sob milho cultivado com adubação mineral e orgânica. R. Bras. Ci. Solo, 27:821-832, 2003.

LOPES, A. S.; SILVA, M. C.; GUILHERME, L. R. G. Acidez do solo e calagem. São Paulo: Associação nacional Para a Difusão de Adubos, Boletim Técnico, 1. 1991.

LUNARDI-NETO, A. et al. Atributos físicos do solo em área de mineração de carvão influenciados pela correção da acidez, adubação orgânica e revegetação. Revista Brasileira de Ciência do Solo, Viçosa, v. 32, n. 4 p.1379-1388, 2008.

MALAVOLTA, E.; VITTI, G. C.; OLIVEIRA, S. A. Avaliação do estado nutricional das plantas: princípios e aplicações. 2. ed. Piracicaba: POTAFOS. 319 p. 1997.

MARCONDES, J. et al. Efetividade na fixação biológica do nitrogênio de bactérias nativas isoladas em plantas de amendoim. Ciência \& Tecnologia: FATEC-JB, 1: 21-32, 2010.

MARIMON, M. P. C; FRANCO, A. C. Tecnologias de recuperação de áreas degradadas pela mineração de carvão e usos futuros do solo. 2012. Disponível em:

http://scholar.googleusercontent.com/scholar?q=cache:eHBUATIKUooJ :scholar.google.com/\&hl=pt-BR\&as_sdt=0,5>. Acesso em: 12 out de 2016.

MARSCHNER, H. Mineral nutrition of higher plants. San Diego: Academic. 902 p. 2012.

MASCHIO, L. M. A. et al. Estabelecimento de espécies florestais em substrato degradado. Boletim de Pesquisa Florestal, v.35, p.39-48, 1997. 
MELFI, A. J.; MONTES, C. R. Impacto dos biossólidos sobre o solo. In: Biossólidos na agricultura. 2. ed., São Paulo: ABES/ SP. p.243272. 2002.

MELO, W. J.; MARQUES, M. O. Potencial do lodo de esgoto como fonte de nutrientes para as plantas. In: BETTIOL, W.; CAMARGO, O.A., eds. Impacto ambiental do uso agrícola do lodo de esgoto. Jaguariúna, Embrapa Meio Ambiente, p.109-141. 2000.

MELO, W. J.; MARQUES, M. O.; MELO, V. P. O uso agrícola do biossólido e as propriedades do solo - in Biossólidos na Agricultura Editores Milton Tomoyuki TSUTIYA, João Baptista COMPARINI, Pedro Alem SOBRINHO, Ivanildo HESPANHOL, Paulo de Campos Torres de CARVALHO, Adolpho José de MELO, e Marcos Omir MARQUES - $1^{\text {a }}$ edição São Paulo: SABESP. 468p. 2001.

MELLONI, R. et al. P adicionado e fungos micorrízicos arbusculares no crescimento e nutrição mineral de limoeiro-cravo (Citrus limonia (L.) Osbeck.). R. Bras. Ci. Solo, 24:767- 775, 2000.

MEHROTRA, V. S. Arbuscular mycorrhizal associations of plants colonizing coal mine spoil in India. Journal of Agricultural Science, Cambridge, Inglaterra, v. 130, n. 2, p. 125-133, Mar. 1998.

MIYAZAWA, M.; PAVAN, M.A.; CALEGARI, A. Efeito do material vegetal na acidez do solo. Revista Brasileira de Ciência do Solo, Campinas, v.17, n.3, p.411-416, 1993.

MOREIRA, F.M.S; SIQUEIRA, J.O. Microbiologia e bioquímica do solo. Lavras: UFLA. 625p. 2006.

MODESTO, P. T. et al. Alterações em algumas propriedades de um Latossolo degradado com uso de lodo de esgoto e resíduos orgânicos. Revista Brasileira de Ciência do Solo, p. 1489-1498, 2009.

MURPHY, J.; RILEY, J.P. A modified single solution method for the determination of phosphate in natural waters. Anais. Chim. Acta, 27:3136, 1962. 
NASCIMENTO JR. D.; QUEIROZ, D.S.; SANTOS, M.V. Degradação das pastagens e critérios para avaliação. In: PEIXOTO, A. M.; MOURA, J. C.; FARIA, V. P. (EDS). Simpósio sobre manejo de pastagens, 11. Anais. Piracicaba, FEALQ. 325. 1994.

NASCIMENTO, F.M.F. et al. Impactos ambientais nos recursos hídricos da exploração de carvão em santa Catarina. In: CONGRESSO BRASILEIRO DE MINA A CÉU ABERTO, 1.; CONGRESSO BRASILEIRO DE MINA SUBTERRÂNEA, 2., Belo Horizonte, 2002. Resumos... Belo Horizonte, 2002.

PARKIN, T.B.; DORAN, J.W.; FRANCOP-VIZCAÍNO, E. Field and laboratory tests of soil respiration. In: DORAN, J.W.; JONES, A. (Ed.). Methods for assessing soil quality. Madison: Soil Science Society of America. p.231-245. 1996.

PEDROZA, E. C. L. et al. Aplicação de Leitos para Secagem de Lodo gerado em Estações de tratamento de Esgotos. In: ANDREOLI, C. V (coordenador). Alternativas de Uso de resíduos do Saneamento Projeto PROSAB. Rio de Janeiro: ABES, 2006.

PEGORINI, E. S. et al. Qualidade do Lodo de esgoto utilizado na Reciclagem Agrícola na Região Metropolitana de Curitiba - PR. In: I Simpósio Latino Americano de Biossólidos. Anais. São Paulo, jun., 2003.

PEREIRA, A.R. Como selecionar plantas para áreas degradadas e controle de erosão. Belo Horizonte: Deflor, 70 p. 2006.

PERIN, A. et al. A. Efeito da cobertura viva com leguminosas herbáceas perenes na agregação de um Argissolo. Revista Brasileira de Ciência do Solo, v.26, n.713-720, 2002.

PHILLIPS, J. M; HAYMAN, D. S. Improved procedures for clearing roots and staining parasitic and vesicular-arbuscular mycorrhizal fungi for rapid assessment of infection. Transactions of the British mycological Society, 55(1), 158-IN18, 1970.

PINTO, L.F.S. Potencial de acidificação e de neutralização dos materiais geológicos para a composição do solo construído em áreas 
de mineração de carvão. (Tese de Doutorado) Universidade Federal do Rio Grande do Sul. 186p. 1997.

PINTO, MT. Higienização de lodos. In: ANDREOLI, C.V.; VON SPERLING, M. FERNANDES, F. Lodo de esgoto: tratamento e disposição final. Belo Horizonte: UFMG; Companhia de Saneamento do Paraná, p. 261-296. 2001.

PIRES, A.M; MATTIAZO, M.E. Avaliação da viabilidade do uso de resíduos na agricultura. Jaguariúna: Embrapa, 2008.

PIRES, G. T. et al. Adição de lodo de esgoto da E.T.E. do município de Jaguariúna em tijolos cerâmicos: estudo de viabilidade. Revista Intellectus, Jaguariúna, ano 8, n. 22, p. 143-158. 2012.

POLZ, J. A. Recuperação de áreas impactadas pela mineração de carvão a céu aberto em Santa Catarina: Gestão de rejeitos e revegetação. In: Carvão brasileiro: tecnologia e meio ambiente. Rio de Janeiro: CETEM/MCT, 2008.

PRIMAVESI, A. Manejo ecológico do solo: a agricultura em regiões tropicais. São Paulo: Nobel. 549p. 2002.

PROCHNOW, L. I.; ALCARDE, J. C.; CHIEN, S. H. Eficiência agronômica dos fosfatos totalmente acidulados. In YAMADA, T.; ABDALLA, S. R. S. (Ed.). Fósforo na agricultura brasileira. Piracicaba: Potafos. p. 605-663. 2004.

PROSAB - Programa de Pesquisa e Saneamento Básico. Uso e manejo do lodo de esgoto na agricultura. Rio de Janeiro: PROSAB. 97p. 1999.

REIS, E. M.; BAIER, A. C. Efeito do cultivo de alguns cereais de inverno na população de Helminthosporium sativum no solo. Fitopatologia Brasileira, Brasília, DF, v. 8, n. 2, p. 311-315, 1983a.

RIELING, R. C. et al. Efeito residual do lodo de esgoto na produção de mudas de espécies nativas para reflorestamento. SaBios: Rev. Saúde e Biol., v.9, n.2, p.31-39, mai./ago., 2014. 
RIO VIVO AMBIENTAL. Plano de Gerenciamento Agrícola de Lodo de Esgoto. Gaspar/SC, 2014.

ROCHA, J. H. T. et al. Composto de lodo de esgoto como substrato para mudas de eucalipto. Pesquisa Florestal Brasileira, Colombo, v. 33, p. $27-35,2013$.

ROCHA-NICOLEITE, E. et al. Mata Ciliar: implicações técnicas sobre a restauração após mineração de carvão. Criciúma: SATC, 2013.

ROCHA, G.N.; GONÇALVES, J.L.M.; MOURA, I.M. Mudanças da fertilidade do solo e crescimento de um povoamento de Eucalyptus grandis fertilizado com biossólido. Revista Brasileira de Ciência do Solo, v.28, p.623-639, 2004.

ROSA, M. E. C., NAVES, R. V.; OLIVEIRA JÚNIOR, J. P. Produção e crescimento de mudas de mangabeira (Hancornia speciosa Gomez) em diferentes substratos. Pesquisa Agropecuária Tropical (Agricultural Research in the Tropics), 35, 2, p.65-70, 2007.

SAMPAIO, A. O. Afinal, queremos ou não viabilizar o uso agrícola do lodo produzido em estações de esgoto sanitário? Uma avaliação crítica da Resolução CONAMA 375. Revista DAE, no 193 set/dez 2013. São Paulo: DAE, 2013.

SANTOS, J. A; DOS SANTOS, V. B; DE ARAÚJO, A. S. F. Alterações na atividade microbiana e na matéria orgânica do solo após aplicação de lodo de esgoto. Bioscience Journal, v. 25, n. 2, 2009.

SERRAT, B. M. et al. Taxa de aplicação máxima anual de lodo de esgoto higienizado pelo processo de estabilização alcalina: estudo comparativo de curvas de $\mathrm{pH}$ de solos. Revista Brasileira de Ciências Ambientais, n. 19, p. 30-37, 2011.

SIQUEIRA, J.O., MAHMUD, A.W., HUBBELL, D.H. Comportamento diferenciado de fungos formadores de micorrizas vesfculo-arbusculares em relação à acidez do solo. R Brás Ci Solo, Campinas, v. 10, p. 11-16, 1986a. 
SIQUEIRA, J.O. et al. The relationship between vesicular-arbuscular mycorrhiza and lime: associated effects on the growth and nutrition of brachiaria grass (Brachiaria decumbens). Biology and Fertility of Soils, v.10, p.65-71, 1990.

SIQUEIRA, J.O.; SOARES, C.R.F.S.; SILVA, C.A. Matéria orgânica em solos de áreas degradadas. In: SANTOS, G.A.; SILVA, L.S.S.; CANELLAS, L.P.; CAMARGO, F.A.O. Fundamentos da matéria orgânica do solo - Ecossistemas tropicais e sub-tropicais. 2 ed. Porto Alegre: Metrópole Editora Ltda. v. 1. p. 495-524. 2008.

SMITH, S.E.; READ, D.J. Mycorrhizal symbiosis. London: Academic Press, 2008. 785 p.

SNIS - Sistema Nacional de Informações sobre Saneamento: diagnóstico dos serviços de água e esgotos - 2013. Brasília, MCIDADES. 2013. Disponível em: < http://www.snis.gov.br/diagnostico-agua-e-esgotos/diagnostico-ae2013>. Acesso em: 10/10/2015.

SHRESTHA, R.K.; LAL, R. Changes in physical and chemical properties of soil after

surface mining and reclamation. Geoderma, v.161, p. 168-176. 2011.

SILVA, I.F.; MIELNICZUK, J. Ação do sistema radicular de plantas na formação e estabilização de agregados do solo. Revista Brasileira de Ciências do Solo, 21:113-117, 1997.

SILVEIRA, A.N.; SILVA, R.D.R.; RUBIO, J. Técnicas para tratamento $\mathrm{e}$ aproveitamento de águas ácidas residuais da mineração de carvão. III Workshop Gestão e Reuso de Água na Indústria. Florianópolis, p.1-6, 2007.

SIQUEIRA, J.O. Micorrizas arbusculares. In: HUNGRIA, Mariangela; ARAUJO, Ricardo S. Microrganismos de importância agrícola. Brasília: Embrapa, 1994.

SOARES, C. R. F. S.; CARNEIRO, M. A. C. Micorrizas arbusculares na recuperação de áreas degradadas. In: SIQUEIRA, J. O.; SOUZA, F. 
A.; CARDOSO, E. J. B. N.; TSAI, S. M. (Eds.). Micorrizas: 30 anos de Pesquisa no Brasil. Lavras: Editora UFLA, 716p. 2010.

SOARES, C. R.F.S; SIQUEIRA, J. O. Mycorrhiza and phosphate protection of tropical grass species against heavy metal toxicity in multicontaminated soil. Biology and Fertility of Soils, v. 44, n. 6, p. 833$841,2008$.

SOARES, P.S.M., SANTOS, M.D.C., POSSA, M.V. Carvão brasileiro: tecnologia e meio ambiente. Rio de Janeiro: CETEM/MCT. 300p. 2008.

SOCIEDADE BRASILEIRA DE CIÊNCIA DO SOLO. COMISSÃO DE QUÍMICA E FERTILIDADE DO SOLO - RS/SC. Manual de adubação e calagem para os estados do Rio Grande do Sul e de Santa Catarina.10 ed. Porto Alegre. 394 p. 2004.

SPINOSA, L. Status and perspectives of sludge management. (2007). In: Conference Proceedings - Moving Forward - Wasterwater Biosolids Sustainability - Technical, Managerial and Public Synergy - 4 $4^{\mathrm{a}}$ Canadian Organic Residuals and Biosolids Conference. Moncton, New Brunsic, Canadá. June 24-27, 2007.

STUMPF, L. et al. Condição física e desenvolvimento radicular de gramíneas em solo construído após mineração de carvão. Pesquisa Agropecuária Brasileira, v. 51, n. 9, p. 1078-1087, 2016.

TEDESCO, M. J. et al. Análise de solo, plantas e outros materiais. Boletim Técnico de Solos, Porto Alegre: Departamento de Solos da Universidade Federal do Rio Grande do Sul. 174p. 1995.

TOMM, G. O. Wheat intercropped with forage legumes in Southern Brazil. Thesis (M.Sc.) - University of Saskatchewan, Saskatoon, Canada. 1990. 122

TRANNIN, I. B.; SIQUEIRA, J.O.; MOREIRA, F.M.S. Características biológicas do solo indicadoras de qualidade após dois anos de aplicação de biossólido industrial e cultivo de milho. Rev. Bras. Ciênc. Solo, v.31, n.5, p. 1173-1184, 2007. 
TRIGUEIRO, R.M.; GUERRINI, I.A. Uso de biossólido como substrato para produção de mudas de eucalipto. Scientia Forestalis, n.64, p.150162, 2003.

TSUTYA, M.T. Alternativas de disposição final de biossólidos gerados em estações de tratamento de esgotos. In: BETTIOL, W; CAMARGO, O. Impacto ambiental do uso agrícola de lodo de esgoto. Jaguariúna: Embrapa Meio Ambinete, 2000.

UNITED STATES ENVIRONMENTAL PROTECTION AGENCY USEPA. Title 40 CFR - Part 503. Final rules: standards for the use or disposal of sewage sludge. Federal Register, 58:9387-9415, 1993.

USEPA - United States Environmental Protection Agency. 40 CFR Part 503. Use of disposal of sewage sludge; biosolids. Washington-US: Environmental Protection Agency, february 19, 1993. Disponível em: Acesso em: 12 out. 2016.

VIEIRA, G.D.; CASTILHOS, D.D.; CASTILHOS, R.M.V. Atributos microbianos do solo após a adição de lodo anaeróbio da estação de tratamento de efluentes de parboilização do arroz. R. Bras. Ci. Solo, 35:543-550, 2011.

VOLK, L. B. S; COGO, N. P. R. Inter-relação biomassa vegetal subterrânea estabilidade de agregados-erosão hídrica em solo submetido a diferentes formas de manejo. Revista Brasileira de Ciência do Solo, v. 32, p.1713-1722. 2008.

WILDNER, L. do P.; DADALTO, G.G. Adubos verdes de verão para o Oeste catarinense. Agropecuária Catarinense, v.4, n.3, p.36-40, 1991. 